Journal of the Scientific Agricultural Society of Finland

Vol. 47: 283-383, 1975

Maataloustieteellinen Aikakauskirja

\title{
ECONOMICS OF FOREST LAND CLEARING FOR AGRICULTURE
}

Selostus: Metsämailla suoritettujen uudisraivausten

taloudellisuudesta

K. U. P I H K A L A

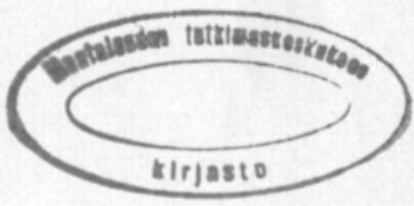

SUOMEN MAATALOUSTIETEELLINEN SEURA HELSINKI 



\section{Preface}

This volume contains in an abbreviated form the main report of a Finnish Study Group formed in 1959 to investigate the economics of alternative use of land for agriculture or forestry. The study group worked within the framework of the Institute of Agricultural Policy, Faculty of Agriculture and Forestry, University of Helsinki. Expert forestry knowledge was represented by the group members, Professor Viljo Holopainen, at present General Director of the Forest Research Institute, and Dr. Matti Keltikangas, today Professor of Forestry Economics. The other members of the group, Dr. Tapani Lasola, of the Institute of Agricultural Policy, Mr. Paavo Väisänen, M. Agr. Sc., Councillor in the Ministry of Agriculture and Forestry, and the writer, Professor Kaarlo Uolevi Pihkala, now retired Head of the Institute of Agricultural Policy, are agricultural economists.

The members of the group have contributed to the planning of this study, in the organizing and supervising of the field work and by some printed publications and unpublished manuscripts. They have further helped by offering comments and by reading through the manuscript. The forest observations in the field work were by Dr. Keltikangas. Dr. Lasola has also helped in the numerical work.

Especially Dr. Arvi Valmari and Mr. Kalervo Hyppölä have given valuable help to the study group in the form of advices and criticisms. We are grateful to them as well to all coworkers on the field, including these hundreds of small farmers who contributed with information.

This research has been mainly financed through a grant made by the U. S Department of Agriculture under P. L. 480 and, at its initial stage, by grants of the Yrjö Jansson Foundation, the State Research Council of Natural Sciences and the Foundation of Natural Resources.

The main report was distributed in the from of mimeographed sheets in 1969. The final revision has been greatly delayed by the author's increased teaching duties and pressure of administrative work in the University.

K. U. Pihkala 



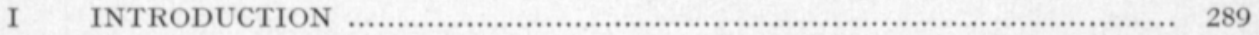

II COMPARATIVE STUDIES ON LAND USE FOR AGRICULTURE AND

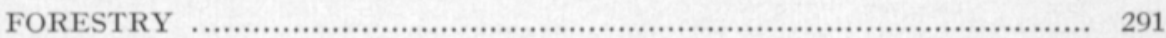

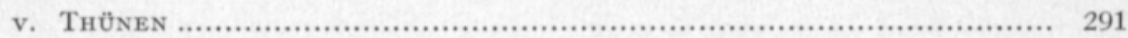

Recent studies in English speaking countries ....................................... 293

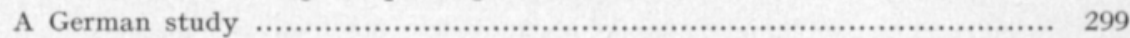

Studies in the Northern countries ...................................................... 299

III AIM AND SCOPE OF THIS STUDY …........................................... 306

IV A FIELD STUDY ON A NUMBER OF PIONEER FARMS IN FOUR REGIONS

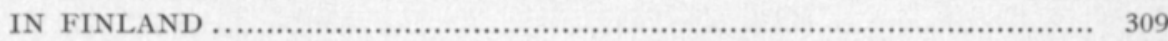

Method used in the field study ...................................................... 309

The data on agricultural production ........................................... 311

Some figures characterizing the land use and economic size of study farms . 311

The main crops and the use of fertilizers and lime ............................... 312

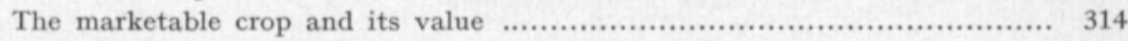

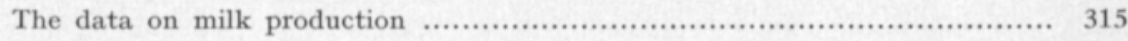

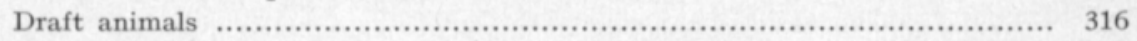

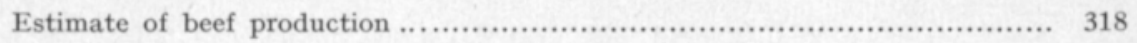

The non-marketable crop and its utilization .................................... 318

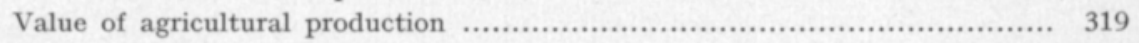

Method of cost estimations ........................................................ 320

Cost of tractive power and field machinery ....................................... 321

Some cost items of livestock production ............................................. 322

Cost of investment in buildings ..................................................... 322

Cost of labour .............................................................................. 323

Balance of return and costs ...................................................... 325

The data on forestry ............................................................... 327

Projections relating to the volume and value of potential cuttings ............ 332

Comparisons with other relevant data ……...................................... 336

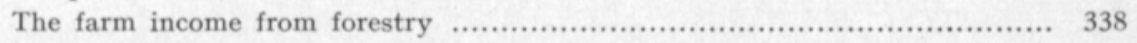

Land rent of forestry compared with that obtained in agriculture ........... 338

V MARGINAL CALCULATIONS ON THE EXTENSION OF AGRICULTURAL

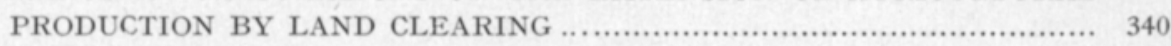

VI LAND CLEARING IN THE DIFFERENT SITE AND AGE CLASSES OF TIMBER STAND ....................................................................... 346

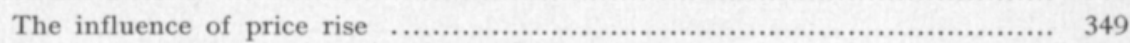

VII THE LINEAR PROGRAMMING APPROACH …................................. 354

VIII ADVANTAGE OR DISADVANTAGE IN SOCIO-ECONOMIC CALCULATIONS 356

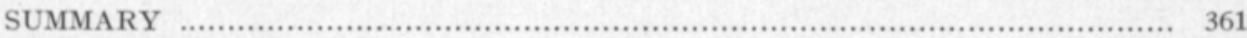

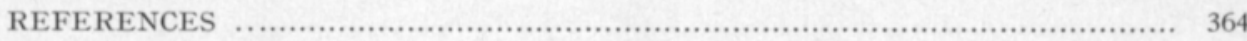

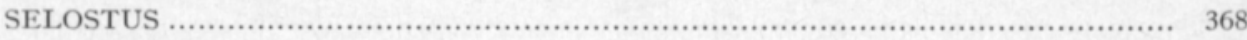

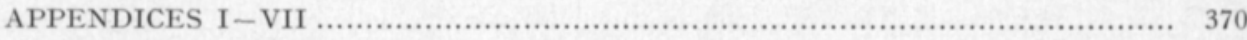

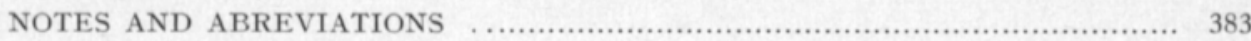



Pinkala, K. U. 1975. Economics of forest land clearing for agriculture. J. Scient. Agric. Soc. Finl. 47: 283-383.

\begin{abstract}
In the literature review an account is given of the methodological problems of the economic comparison of land use for agriculture or forestry. In the empirical study, the comparison is focused on situations where a decision on the possible transfer from forest to agricultural use may have current interest. On the basis of data, mostly collected from pioneer farms established after the war on forest or peat land within four main study areas in Finland, estimates of gross margin, social output, labour income and land rent are made, using the price structure of $1959-63$.

The comparisons indicate among other things that although agricultural land rent in the existing structure of farm size is often negative, the land rent in marginal calculation may be positive. The land rent is neither the sole criterion of land use to the farmer, nor to the national economy, as the labour income plays an important role. The farmer's problem is to find the optimum combination of agricultural and forest activities. In the national economy, not only labour in primary production but also in secondary and tertiary industries has to be considered. The economic losses caused by badly timed forest land clearing are illustrated by calculations.
\end{abstract}

\title{
I. Introduction
}

State support for pioneer farming and forest land clearing for agriculture has old traditions in Finland, it was in fact established already during the last decades of the Swedish era. After the hunger period of the first year of Independence, 1917-18, certain measures to promote land clearing were introduced. In the year 1928, special legislation providing financial support to smallholders willing to enlarge their fields by forest or waste land clearing was enacted. The policy of subsidizing resulted in an enormous increase in the cultivated area. Until the outbreak of the Second World War, approximately 200000 hectares of land had been cleared under subsidy schemes.

Subsidies were, again, to a large extent used to promote land clearing needed for the post-war resettlement of the displaced population from the Karelian territory ceded to the U.S.S.R. This practice continued also after the completion of the resettlement programme. During the period 1945-60 approximately 300000 ha were cleared for cultivation or pasture, an area that exceeded the cultivated area left behind the new borderline. The total increase 
of arable land far exceeds corresponding increases in any other European country.

Subsidized land clearing has been criticized, in the first place, as promoting surplus production in agriculture (see footnote p. 299). The outbreak of the war put this problem in a new perspective; and the necessity of new land clearing was now commonly accepted.

After the recovery of agricultural production in the first half of the 1950's, the appropriateness of subsidizing land clearing was again questioned, and the Committee on Agriculture, in its report (Kom. miet. 1962, p. 122) recommended the termination of subsidy allocations. Allocations for this purpose were, however, included in the State Budget without substantial reductions until 1968.

While more emphasis has been laid on the necessity to increase forestry production, the subsidizing of land clearing has in recent years had to give way to promotion of afforestation and other measures promoting forestry. Irrespective of the aims of Government policies, there is a need for objective information on the productivity of land in both alternative uses. Such information is equally useful for decisions an afforestation and on land clearing.

Interest in studies concerning the comparative advantage of land use alternatively for agriculture or forestry was, during the fifties, rather lively among others in the Northern countries. As will be seen, several studies have since been made on this theme. It may be mentioned that a working group was set up in Norway for these studies, and the Nordisk Jordbruksforskares Förening organized a seminar in December 1958 in Prestebakken, Norway, to discuss problems conenctid with this topic.

The plan of the present study developed gradually from some simple calculations made by the author during the first postwar years. Various aspects of the research problems, some of which had been discussed also during the above mentioned seminar, have been discussed in a preliminary publication (Prhkala, 1964). The study includes also empirical data concerning the price trends and calculations presented to the Committee on Agriculture (1961). 


\section{Comparative studies of land use for agriculture and forestry}

Although the comparative study of the economics of land use has a long tradition starting with von THÜNEN's classical work, the number of recent studies where economic comparisons between alternative uses of land for agriculture or forestry are made, seems to be rather small. No such study can give a general answer valid in any other natural and economic conditions than those prevailing in the sphere of the respective study. The empirical results of such studies are thus of no special interest to us. The method used in various studies, is however, interesting from the point of view of this study. A brief account of the studies available to us is therefore given.

\section{v. Thünen}

The method used in v. Thünen's famous book "Der isolierte Staat", the first edition of which was published in 1826, is of sufficient interest to be first reviewed here (v. THÜNEN 1875).

The purpose of v. Thünen's study was to demonstrate why the geographic location of various lines and intensity levels of agricultural production shows certain regularities. The model used was an imaginary State, isolated from the rest of the world, with a homogeneous soil and climate, and only one market centre, the Town, in the centre. The empirical data were based on detailed book-keeping records of the estate Tellow, at a distance of $37.5 \mathrm{~km}$ from the market place of Rostock, Mecklenburg. The soil there was first class "barley" soil, and the rotation "Koppelwirtschaft" (fallow, 3 grain crops, 3 leys). The calculations concerning other intensity levels (among others Dreifelderwirtschaft, Fruchtwechselwirtschaft) were deduced mostly from the data of Tellow, assuming certain hypotheses on the equilibrium of plant nutrients in different rotations, and utilizing work time records of various field operations. Some data concerning intensive agriculture were, however, cited from a study on Belgian agriculture, where the actual data of Edegem farm, south of Antwerp, were used as representative data. All costs were expressed partly in Scheffels $(=0.544 \mathrm{hl})$ of rye which were valued on the basis of the market price in the Town from which transport costs were subtracted, partly in money (Thalers). The former costs decreased with the growing distance from the Town, the latter, supposed to be determined in the Town itself with its higher costs of 
living (eg. the products of industry, the salaries of officials educated in the Town), were independent of the distance to the Town. The larger the share of mining, industry and trade in the rural area, the smaller the part of the costs expressed in money and independent of the distance from the town. v. THüNEN used the ratio $3 / 4: 1 / 4$ between the former and the latter part of costs. The labour time requirements were assumed partly as fixed per areal unit, partly varying in the same proportion as the crops.

The calculations relating to forestry are in the edition from the year 1826 based on an approximate estimation of the growth of a 100 years' beech stand; it was admitted that the estimate was not founded on reality. v. THÜNEN assumed a sustained yield from plots of equal size representing all age classes. The yield in the form of thinnings and final cuttings was estimated at 1000 cords (à 5.51 cu.m) from a total area of 100000 square rods $(217 \mathrm{ha})$, for the paying of five per cent interest to the capital in standing timber (which was estimated as 15 -fold the value of yearly cuttings) 750 cords would be marketed, while the remaining 250 should cover the other costs of production as well as land rent as an opportunity cost. Land rent was calculated for rye giving $\mathbf{8}$ bushels per square rod, i.e. $20.08 \mathrm{hl}$ per hectare and priced $1.5 \mathrm{Th}$. per bu in the Town, as a function of the distance to the market place, being e.g. equal to 1066 Th. when the distance is $7.5 \mathrm{~km}, 893 \mathrm{Th} .37 .5 \mathrm{~km}, 685 \mathrm{Th}$. $75 \mathrm{~km}$. To find the largest possible error, alternative calculations presuming a very large (eight-fold) variance either in the costs or in the yield were presented for comparisons. If the price of fuel wood per cord was assumed to be $21 \mathrm{Th}$. in the Town, and the assumptions of yield and costs were tenable, forestry was best competitive within distance, of 30 to $52.5 \mathrm{kms}$ from the Town.

In this connection $\mathrm{v}$. THÜNEN already noted the value growth occasioned by a lengthening of the rotation period, but also the drawbacks caused by a retarded volume increase. Higher priced sawlogs were more advantageously produced at a longer distance than fuel wood; the leavings after timber cutting could be marketed as charcoal. It was difficult to unite a rational sustained yield forestry with an interest rate higher than the natural value growth; the purely economic reasons favoured the realisation of the timber stand.

In the third volume of $\mathrm{v}$. THÜNEN $\mathrm{s}$ work, posthumously published in 1863, more detailed calculations on forestry were presented. They refer to Tellow pine stands, which with proper thinning could have a total growth of $76.8 \mathrm{cu}$. ft. per square rod $(=8.71 \mathrm{cu} . \mathrm{m} / \mathrm{ha})$ in from 5 to 30 years; this growth should, according to the author continue in equal volumes yearly except in the old age classes. The stumpage price of the yield, consisting of two-fifths of fuel wood, three-fifths of wood for fencing posts and roof poles, was on an average 0.9 shillings per cu.ft $(=0.76 \mathrm{Th} / \mathrm{Cu} . \mathrm{m})$. The yield of a 100 -year stand was assumed to consist of two-thirds of building timber, priced at $4 \mathrm{sh}$. per cu. $\mathrm{ft}$. (=1.62 Th/cu.m), the remainder being used as fuel. v. THÜNEN here assumed a linear rise in the stumpage price of stands between 30 and 100 years of age and, the value formula (third grade function) of the stands in varying age classes was thus derived.

v. THÜNEN subsequently devotes himself to extensive speculations on the effects of thinnings on the growth and the economic results of forestry. 
He introduces the concept of forest rent, which includes the interest to the standing timber capital, and notes that while the forest rent increases with the lengthening of the rotation period, the land rent reaches its maximum at a point which is dependent on the intensity of thinning. Having studied the theory of a contemporary forester who recommended thinnings to such an extent that only half of the yearly growth remains in the stand, v. THünen develops his own ideas, to some extent based on observations, on the optimum distance of trees in relation to the diameter. He comes to the conclusion that the highest land rent is obtained by thinnings which are heavy in the beginning (two-thirds of the growth), but gradually decrease with the age of the stand (being e.g. 1/3 in stands of $45,1 / 5$ in stands of 85 years). The optimum period of rotation was estimated at 90 years; the rate of interest was assumed to be 4 per cent.

As the result of elaborate calculations $\mathrm{v}$. THÜNEN presented his comparison of the relative advantages of agriculture and forestry, which refers to five site quality classes of land and the market conditions of Tellow. It was assumed that the volume of cuttings was directly proportional to the rye crops typical for the respective site classes. The land rent in agriculture (the existing Koppelwirtschaft in Tellow), in forestry (pine stands in Tellow), the ratios of these, and the forest rent are reproduced, converted in to metric measures, in the following tables.

$\begin{array}{ccccc}\begin{array}{c}\text { Site quality, } \\ \text { measured by } \\ \text { the crop of } \\ \text { rye (hl/per ha) }\end{array} & \begin{array}{c}\text { Land rent, } \\ \text { agriculture } \\ \text { Th/per ha }\end{array} & \begin{array}{c}\text { Land rent, } \\ \text { forestry } \\ \text { Th/per ha }\end{array} & \text { Ratio a/f } & \begin{array}{c}\text { Forest rent, } \\ \text { Th/per ha }\end{array} \\ 25.1 & 6.28 & 10.00 & 0.628 & 21.16 \\ 22.6 & 4.86 & 8.92 & 0.560 & 18.96 \\ 20.1 & 3.59 & 7.85 & 0.474 & 16.78 \\ 17.6 & 2.44 & 6.77 & 0.361 & 14.59 \\ 15.1 & 1.17 & 5.70 & 0.206 & 12.40\end{array}$

The figures indicate a distinct comparative advantage of forestry, a result which $\mathrm{v}$. THÜNEN himself found startling and highly noteworthy. The advantage of forestry was largest in high site qualities which, according to v. THÜNEN, contradicted the prevailing opinion. He maintained, however, that in reality, the land rent of forestry in lower site classes may still have been overestimated, as the lower yield consisted of a smaller proportion of building logs than of larger size timber.

\section{Recent studies in English speaking countries}

In Great Britain, after the Second World War, land reclamation as well as afforestation measures have been discussed. During the War, land reclamation was used as an effective means of raising agricultural production (e.g. TRIsT 1948). Later the rival efforts to achieve food and timber self-sufficiency and thereby to improve the national balance of payments caused differences of opinion between the Ministry of Agriculture and the Forestry Commission, 
especially with regard to the future use of hill land. Without an economic criterion for a comparison of land use in agriculture or forestry, the planning of land use proved to be difficult.

Notable attempts to solve this problem have been made by WALKER (1958) and the Land Use Study Group set up by the Committee on Agiculture of the Natural Resources (Technical) Committee (1966). The contribution of MAC Gregor (1959) should also be mentioned.

WALKER's study (1958) concerns the major hill land areas of Great Britain (Scotland and Wales), and is based on data of costs and returns for 1953. The agricultural data were obtained from reports published by the Colleges of Agriculture in Scotland and from primary records of the Ministry of Agriculture's Farm Management Survey. A great deal of the information on forestry was obtained by the Forestry Commission or by eminent scientists. According to the author "a forest cycle of $\mathbf{5 0}$ years is assumed; so that the comparison is between the net value added per 100 acres under 50 years with the aggregate of the annual land products per 100 acres under agriculture, each year's product accruing at interest from the year of origin to the fiftieth year. The net value added by land is obtained by exhausting the gross product (net of direct subsidies) of all non-factor and factor payments except payments to land itself, The residual is then a measure of the value added by land alone, or the price which might be paid for the use of land." The net product of land in forestry was obtained from estimated gross receipts, accruing at compound interest from the year of origin to the fiftieth year, subtracting costs, similarly prolonged at compound interest. Five alternative rates of interest, viz. 3, 4, 5, 6, 7 per cent were used, in addition four alternatives of future development in wages and prices were assumed.

The results of this study - an extract of which is included in Table 1 below - point to a distinctive comparative advantage of forestry, when the interestrate is 3 , often even when it is 4 ; if there is a yearly rise of 1.5 per cent in relative timber prices, even when it is 6 (in two regions even 7). The author believes that the results for forestry can be still better, as a $10-15$ per cent fall in costs could be attained by economics of scale, and by eliminating the burden of compound interest, after establishing forests on a basis of sustained yield.

The Land Use Study Group (1966), discussing methodology, first defines the choice of indicator, profitability, stating that wif there is no limit on the availability of capital or labour at their market price, then the activity which should be favoured is that which makes the biggest profit per unit area after all costs, including interest, have been taken into account." Where the capital available over a certain period is insufficient to cover all demands placed on it "the activity yielding the highest profit per unit capital should be preferred." For the purpose of the study both situations were considered.

In the calculations of the Study Group, the different time spans of the two activities are overcome by discounting future expenditures and revenues to the initial year of the project. Three alternative rates, 3,5 and 7 , are used. It has been emphasized that the rates adopted are real rates and do not contain any element to cover possible future inflation. The difference between the discounted revenue (D.R.) and discounted expenditure is called net discounted 
revenue (NDR). It represents the discounted profit from the undertaking over the whole appropriate rotation. This profit is, according to the purpose in question, related to acreage (NDR per acre) or to capital investment (NDR per $£ 100$ capital). Capital has been defined as sthe outlay required to embark on a particular enterprise, and the further expenses incurred up to the point at which it becomes self-financing." - In addition, a third indicator, the wellknown internal rate of return, is used.

The Study Group has been interested not only in the profits to private economy, but also in the returns accruing to the Nation from both alternative uses. In principle, the revenue derived from subsidies should have been eliminated in calculations concerning the latter.

This has been done in the case of production grants and subsidies. A simple deduction of market price subsidies was, however, in the opinion of the Study Group unlikely to result in prices which would correspond to factual prices in a hypothetical situation brought about by the removal of subsidies. Market price subsidies have therefore been included in most calculations on the return to the Nation.

Twelve areas were selected for the study. In the first place on the basis of reliability of data, further, looking for a variety in soil types and in the aspect of scale as it affects current management. Nine areas consisted of marginal, partly unreclaimed land where investments were needed, while in three areas land was currently being farmed at a high level of production. There were cases where the calculations were made for the whole farm (involving full budgeting), and others, where a given additional area was assumed to be taken into use e.g. by reclamation, which involved partial budgeting. There exists a certain comparability with WALKER's study areas.

The prices used in calculations were those prevailing in 1962-64. A forecast of a $\mathbf{1 . 5}$ per cent rise in the overall prices of industrial wood, in real terms, is however presented in the Report.

As a general conclusion, the Study Group states that mon the extensively farmed marginal areas, agriculture earns a higher return to the Nation and the private owner than does forestry unless the discount rate is a low as $3-4$ per cent; and, in areas of better quality farm land, the profitability of agriculture is higher than forestry even at a discount rate as low as 3 per cent." (p. 64.) Under the hypothesis that market subsidies are removed and the prices remain correspondingly low the majority of the land in the selected areas is unsuitable for profitable agriculture or forestry at discount rates at or above 5 per cent (p. 79.)

A direct comparison of the results of WALKER and the Study Group is difficult because the latter is using discounted values, while the former uses values covering the entire rotation period for forestry, but, as it seems to us, simple interest rate accrued values with a yearly increasing trend for agriculture.

Regarding forestry, the net discounted revenue (NDR) per acre can be made comparable to the land rent when it is divided by the interest rate used in discounting.

An interesting feature mentioned in the Report of the Study Group is that forestry in an upland area employs more men per unit area than agriculture. 
Employment per 100 acres has been on plantations of forest 0.67 , in agriculture, on all holdings 0.24 and on full-time farms 0.16 man years.

MAC GREgor (1959), in a paper prepared for a course on Land Use for Forestry and Agriculture, discusses several points of view while aiming at comparable calculations of the alternative land uses. He stresses the importance of the rate of interest in forestry calculations, where interest on capital assumes large proportions in the structure of costs, which is applicable irrespective of "whether the forest authority borrows capital from a governement Treasury or not - and whether it pays interest or not - for although capital may be free to authority it is not free to the economy." The opportunity cost is here the most relevant one. - Finding the physical factors fairly obvious, Mac Gregor thinks it reasonable to expect that the productivity influences in forestry are similar to those in agriculture, while according to him submarginal land for agriculture may often be supra-marginal for forestry and vice versa.

A different approach to the problem was adopted in a much earlier study in the U.S.A., performed under the guidance of JoHn D. BLACK by Messrs. BARRACLOUgh and Gould (1954). In this study the optimum combination of agricultural and forest production has been investigated. On the basis of an analysis of a number of farms in New England, production plans were made for nine farms of varying conditions. Three intensity levels of forestry, two assumptions of sawlog prices, and three investment plans for livestock production with wholesale milk production as the main line, were taken as alternatives. The calculations on forestry have been made for nine future decades, but the discounting has been left to the owner himself. The preferences of owners for immediate returns over future returns are. according to the study, correlated to the extent at which the existing net farm income maintains their present standard of living, in other words, they seem consistently to discount future returns at a high rate until current income increases to a certain minimum level, thereafter their rate of discounting future income drops sharply. The authors present a number of input-output data and stress the importance of more work for developing better data.

The linear programming approach has been applied in more recent studies on land use planning in the Tennessee Valley watershed area. Coutu and Ellertsen (1960) have tried by this method to find the most profitable enterprise combinations on individual farms, when forestry activities are considered along with a different line of agricultural production. They took into account different alternatives in forestry management, intensity of stand development, and extent of processing. Different alternatives in factor and product prices and rates of interest $(3,5,10$ per cent) were also assumed. For all enterprises budget estimates of the amount of resources required to yield a specified $(100 \$)$ net income were made. The discounted forestry income was converted to an annual basis by using the annuity concept (cf. below, p. 346). Family labour was not assumed to be used in forestry operations as the estimates were based on stumpage values. The method was applied on two case farms, of which one was a small farm, the other a large one. The optimum use of resources provided no forestry activities on the small farm (8 hectares), except in 
highly favourable timber price conditions (threefold future increase of prices). For the large farm (100 hectares), the use of two-thirds of the land area for forestry, including nearly one third for afforestation by planting was optimal, if a discount rate of 3 per cent, investment of $9500 \mathrm{~S}$ and good forest management were assumed.

Later, further studies were published by Ellertsen and Le RoY Rogers (1965 a, 1965 b) who used the data on six farms in Henderson County, Tennessee. The farms included a selection of sizes ranging from 28 to 116 hectares, of typical soils and different timber growing sites and forest stand conditions. Timber and other farm resources were inventoried, basic input-output data needed for complete farm planning analyses were assembled, and operating plans for each farm were prepared employing linear programming procedures.

Several alternatives were presented on similar lines as in the former study. Thus, e.g. three price level alternatives were used for timber: current prices, an average annual increase of 2.5 per cent for the following 25 years, and a respective 5.0 per cent increase. Four discount rates, 4, 6, 10 and 15 per cent, were applied (p. 12). A rotation period of 70 years was selected for calculating the present average annual income. The total amount of available labour was determined by the number of men and boys in the farm operator's family and full-time tenants on the farm. Seasonal restrictions were imposed taking into account the additional limitations caused by the weather. The computations indicated generally a good competitiveness of forestry; even based on current stumpage values and a discount rate of $t 6$ per cent, the land optimally allocated to forestry ranged from 18 to 77 per cent of the whole farm area (p. 15). Conversion of natural (hardwood) stands to pine plantations was profitable only at low discount rates. Stumpage prices were for pulpwood 4 and $2 \$$ per cord, for average sawtimber 30 or $20 \$$ per 1000 board feet (resp. for pine or hardwood). ${ }^{1}$ )

In the Southern Hemisphere, two contributions, those of THOMson and Grainger (1961) and Treloar and Morison (1962) have been recorded.

The former presents some bases for comparing the relative economics of farming and forestry in New Zealand. The authors who are forest economists do not claim full validity for their results which they regard as preliminary for suggested continued research; and refer to many difficulties, e.g. unequal attainments in farming and forestry techniques. They set as their goal compaisons made on a national, regional, or an individual property basis. The national calculations should be based on prices of the products at the end of the first cycle of production, e.g. factory ex-dairy, ex-woollen mill, ex-sawmill, ex-pulp or paper mill. The above set of comparisons applies only after the forest is a going concern while it ignores the lengthy unremunerative development stage.

Taking a local example - for a large forest complex in central North Island (Murupara and Waipa Working Circles, Kaingaroa and Whaka forests, 279000 acres), the ex-mill value of products was in $1960 £ 34.10 \mathrm{~s}$, but which was estimated to increase to $£ 63$ per acre. The figures on farming are from farms

1) $\mathrm{MBF}=1000$ board feet $=219 \mathrm{cu} . \mathrm{ft}$. (2.36 cu.m.) Tapion Taskukirja, 15, p. 425 . 
of an average efficiency on better sites of the same type of soils. The sheep farming gives $£ 24$, while only 10 per cent of the area would be suitable for dairying, with a gross return of $£ 46$ per acre. If export values only are taken into account, all North Island contributions to export are $£ 20$ per acre in farming and $£ 40$ per acre in forestry, or, if the import requirements for production are deducted, respectively $£ 18.10 \mathrm{~s}$. and $£ 34.0 \mathrm{~s}$. per acre. If the forestry products are processed and sold as newsprint, it can theoretically be as much as $£ 124$ per acre (assuming an annual growth of 240 cu.ft. obtained from radiata pine on an average site). The employment in forestry up to the end of the primary stage of production, according to statistics relating to the whole of New Zealand in 1956, indicates twice as many men per acre as in agriculture, viz. 1 man per 96 acres in forestry, 1 man per 197 acres in farming.

TRELOAR and Morison (1962) have made economic comparisons of forestry and agriculture in three areas (Chapman Forest, Blackwood Valley and Naturaliste - Leeuwin Horst) in Western Australia. These areas are mostly State or Corporate owned forest land, but regarded as potential areas suitable for clearing for farming. The first study investigates the economics of retaining a tract of forest for the production of hardwood and associated timber products or clearing it for farming; the second and third relate to the comparative economics of pine plantations and farming of various types. A choice of aims that are set in a wider framework than that of the individual farm or locality. The effects of the eventual decisions must, according to the authors, be traced throughout the systems of industries that supply the factors of production, and process the products of each alternative local activity. There are, however, according to the writers, limitations set by difficulties of getting data, and an approximation, where comparisons are made between agriculture at the farm gate and forestry at the level of producing seasoned, dressed timber, pulpwood, or peeled logs, seemed appropriate. The current prices were regarded as valid indicators of social benefits and costs. The authors further assumed that gross incomes resulting from a particular activity provide an approximate measure of the manner and degree to which economic activity in general is affected by that activity.

In the methodical part an interesting discussion on the limiting factors in trying to attain optimum results in presented. It is suggested that the capital, regarded was the sum of actual costs of short-term and long-term services and the costs imputed to any sacrifices of opportunities which may be involved in the use of certain factors of production but which are not covered by transactions", is the limiting resource for long-term national aims in Australia. On the other hand, the policy-makers concerned with the use of land, according to the authors, tend to overlook the relative productivities of the non-land resources. Entrepreneurs who are bidding for tracts of land appear to view the problem similarly, being disposed to impute residual net incomes to land, thus establishing the maximum price they are willing to offer. Thus, in the opinion of the authors, there is some justification for establishing quantitative criteria on the assumption that land is the limiting factor.

The results of this study are only partially available in printed form. Some results concerning the Blackwood Valley are included in Table 1. The forestry 
calculations refer to Pinus radiata on site quality II. The sawn product of a 40 year felling cycle was, according to Forest Department records, estimated at $8708 \mathrm{cu} . \mathrm{ft}$. per acre; this corresponds to $1185 \mathrm{cu} . \mathrm{m}$ round wood per hectare. The price per cu.ft. was $£$ (Austr.) 0.6978 resp. 0.222 Engl. $£$ per cu.ft. round wood. The net value, after deductions of costs, was 39.5 per cent of the gross value. There were some alternatives for agricultural calculations, one corresponding to 21 average farms, with 260 ha farm land area; this case is taken into Table 1. The others refer to better than average farms or hypothetical budgets. The butter price used in the calculations was $3.83 \mathrm{~s} . / \mathrm{lb}$, whereof 0.69 $\mathrm{s} . / \mathrm{lb}$ as bounty; the export price was $3.03 \mathrm{~s} . / \mathrm{lb} .^{1}$ )

\section{A German study}

A paper presented by ABETZ (1960) in a meeting of a Committee of Land Consolidation, is of interest in this connection. In his study, gross and net return, farm and family income from farming and farm forestry, are compared on the basis of data of the Green Report (Grüner Bericht) of $1957 / 58$ and of the author's calculations, based on studies on farm forests in South Baden (Südbaden); generally the figures refer to the territory of Baden-Württenberg. Large farms are not included in the study. Four types of cultivation: forage, grain combined with forage, grain combined with root crops, root crops combined with grain, are taken into account; forest consisting of spruce with normal age structure and a rotation period of 90 years, and site quality characterized by an average of $10.2 \mathrm{cu} . \mathrm{m}$ yearly growth by 100 years rotation is assumed. The price per cu.m has been estimated, according to the prices prevailing in April 1959 and with an arbitrary correction, at 56.0 DM. The labour requirements in forestry are estimated at 1 man-year per 30 ha forest land.

The average results of farming are compared with those of forestry in Table 1. It is further stated that equal gross incomes have been obtained on a 26 ha forage farm and on a 33 ha forest area.

\section{Studies in the Northern Countries}

In the Northern Countries, especially since the latter half of the 1950's, lively interest in comparative studies of land use has been evident. ${ }^{2}$ ) In Norway, a stipulation in the Land Law of 1955, enjoining the authorities to adopt social-economic evaluations as the basis of decisions concerning land use, was a starting point. Attempts to fit the trend of agricultural production to the trends of domestic consumption have initiated similar studies in Sweden. There has been interest in these studies also in Denmark and Finland.

\footnotetext{
1) Australian $£$ is 0.796 English $£$.

2) In Finland, JÄNNES presented some calculations already 1939, followed by some criticisms and comments by Marttila (1939 a and b), Kaitera (1939) and Helander (1939).
} 
The contributions of Krog (1954), Jørgensen (1956) and HJelm (1956) are among the first and deserve to be reviewed here.

KROG (1954) ha made the first comparative calculations on the social output of agriculture and forestry. He applies the data of national product calculations, thus aiming at the social output (gross output minus the value of material and services from other sectors, as well as the depreciation of the capital). This social output is set in relation to the agricultural area of the country. As to the forestry social output, this is estimated on the basis of the yield tables of Det Norske Skogsforsøksvesen (Norwegian Forestry Experiments) separately for the three best site quality classes, with respective yearly growths of $10.8,8.2$ and $6.1 \mathrm{cu} . \mathrm{m}$ per ha. Another estimate is made taking into account also the social income earned for the part of the produce of each type of forestland, in wood-working industries. Comparisons are made for the periods $1930-34,1935-39$ and $1940-50$, and the results of the last mentioned period are included in Table 1.

JøRGENSEN (1956) compares two alternative uses of a given forest area: continuous use as forest or turning it by reclamation under cultivation into an established new farm. Like Krog, be uses the yield tables taking into account the three best site classes. The agricultural data are the book-keeping results of six size classes of farms in the period 1952-53 from Norges Landbruksøkonomiske Institutt. Two sets of calculations of net return and family farm income, average and marginal, are presented. The forestry marginal returns are estimated simply by omitting overhead costs, which are assumed to be unaffected by small changes in the area. A marginal return in agriculture, caused by an extension of the cultivated area, may in most cases be larger than an average return, because of the economics of scale (lower labour use per unit, lower costs of fixed capital). An extract of comparison, taking data from size class II (farm inn-mark area 7.22 ha) for agriculture, site class B for forestry, and interest rate 3 in both cases, is reproduced in Table 1.

Introducing the marginal principle into the calculations is very important for a correct judgement of various cases of practical relevance. This principle is applied in some calculations presented in the same year by $\mathrm{HJELM}_{(1956) \text {. }}$ Hjelm considers the use of land rent as a measure of the economic advantage of land use, but prefers its capitalized value (sincome valuen, avkastningsvärde), a concept which is evidently more familiar to the foresters. This latter value is calculated either as an average within a size class, or, deriving from the function which indicates the relation of the income values to the size of farm, as a marginal value. In addition, the labour income, per hectare and man hour, is estimated in this case, assuming no rent to the land or the direct investments in land. The calculations on agriculture, although one can agree with the author as to some doubts about the applicability of the used data, are so detailed that not only four farm size classes, but also three different field sizes, and distances to fields, as well as five crop yield levels, have been examined. Two alternatives, one assuming that buildings and land equipment are not at hand and will have to be procured for continued management of the farm; the other implying that no investment is needed in this respect. The data are from bookkeeping records (Jordbruksekonomiska undersökningen) $1950 / 51-1952 / 53$, the 
South and Central Sweden forested regions and Norrland being chosen as the study areas.

The forestry calculations, elaborated by Professor HAGEerg at Statens Skogsforskingsinstitut (Forest Research Institute), were based on standard figures for yields and costs in some comparable site quality classes in Småland and Norrland, and two alternative price levels, one representing 1953/54 market prices, the other a price level 20 per cent below the 1954 prices. The gross prices include costs of logging, net prices were estimated by deducting both direct and indirect costs of logging. Four alternatives of transport costs were further presumed. There is no reference to the used rotation period; probably the optimum period is chosen. No marginal approach has been aimed at in the forestry calculations. It is interesting that Hagberg presents in his tables only land rent figures, while $\mathrm{Hjelm}$ in his diagrams has used capital values deduced from these.

The large number of calculations for various situations facilitates the use of Hjelm's study in practical planning. Rough comparisons can be easily made using the graphics presented. As a very general summing up it can be said that if buildings and land improvements are already at hand on the farm, the income value (discounted net revenue) is generally greater in this form than in forestry, provided that there will be a yield of 2000 to 3000 crop units per ha. There is still a wide margin between the best and the least favourable alternatives in forestry.

In the calculations of $\mathrm{Hjelm}$, the land rent in agriculture in most cases appears to be negative, as the family labour is priced according to the tariffs for hired workers. The figures chosen for Table 1, however, refer to the optimal cases, where the size and distance of the fields are favourable, the crop yield is 2000 or $2500 \mathrm{f} . \mathrm{u}$. The figures of labour income are calculated by adding the land rent to the compensation of labour according to prevailing wages in forest work, and dividing the sum by the number of hours used per hectare in forestry.

A research team was formed in 1957 in Norway to establish the principles to be applied in the economic comparisons of land in agriculture or forestry. In the report of the team (Anvendelse av jord 1959), recommendations for socio-economic as well as managerial calculations were presented. As relatively measurable criterions, rentability, liquidity and security were mentioned. Rentability was defined as the expected long term economic result (net return), the returns in different points of time were made commensurable by discounting with a fixed rate. The liquidity, according to the team, could not be expressed by one figure; the basic living costs of the enterpreneur, however, as well as the availability of credit were relevant in this evaluation. An assessing of the discount rate according to the degree of liquidity which was to be expected in future, was recommended to avoid crises of liquidity. The application of the theory of choice (valhandligsteori) was suggested. The evaluation of security was based either on a certain minimum of own capital, or a predetermined minimum of liquid net return; there was no unanimity on the measurability of this criterion.

The team recommended both average and marginal calculations. In principle, the effects of the change in area were obtained by determining the difference of returns and costs of the whole enterprise before and after the change. The 
prices of labour and capital were determined generally according to the principle of the opportunity cost. In the socio-economic calculations the use of import or export prices was recommended or consumer prices reduced by costs of processing and transportation.

Some studies based on empirical data have been publiched, following the principles suggested by the team. In a study of Elstrand (1961), a budgeting method has been used to test the results in economy of a possible change of land use of two blocks of a farm. Thormodsaeter and Elstrand (1960) analyzed the book-keeping records of some twelve farms in Agder in 1950-57, to find out the returns from agriculture and forestry (see Table 1), and introduced three alternative plans for improved combination of resources. BJoR (1962), also using the budgeting method, tries to find optimum combinations of activities on various types of farms consisting of 6-12 hectares agricultural and 50-150 hectares forest land. The age composition of forests deviates from even-aged stands, and more refined calculation methods are therefore applied. The combination of forestry with milk production appears to be less advantageous than combining it with a farm plan with low labour requirements, such as sheep or grain farming. Some interesting calculations on the results of capital transfers between agriculture and forestry are also presented. Bossibilities of adjusting the fellings in time to the capital requirements are taken into consideration, and a formula of "balance quantum" - the maximum yearly cut allowing a sustained yield - is introduced.

In a study, made jointly by ELSTRAND and BJORÅ (1964), the marginal approach is applied to find out the capitalized value of land in agricultural or forest use. The marginal estimates are carried out in three different ways. The first method, which is based on farm records, is carried out by subtracting the total land value for farms of one size group from the total land value of farms of another size group. The difference is then divided with the difference in acreage for the two size groups and gives thus a rough estimate of the marginal land value (essentially the same method which was used by Jørgensen and Hjelm). The second method which is also based on farm records, is marginal estimates derived from the Cobb-Douglas production functions. The third method comprises estimates of the land value when the land is used for certain enterprises such as barley, pasture, milk production or sheep. Both the average and marginal land values are positive in agricultural production when the price of labour is $2 \mathrm{Nkr}$ or less per hour, according to the calculations by the first method; both the other methods give larger values than the first.

In the calculations on forestry made by Bjorå, three different concepts are applied, viz. first the ground value (grunnverdi), soil value following the terminology of e.g. ButrRIck (1948), which he regards as the average use value, (gjenomsnittlig bruksverdi) where (capitalized) costs varying with time are subtracted. If the time costs are not subtracted, one is dealing with the marginal use value (marginal bruksverdi). The second concept is the expectation value (venteverdi) which is applied in cases where forest production is already taking place. These may likewise be conceived either as average or marginal. Thirdly, the realization value (realisasjonsverdi), presenting the net value of potential fellings. The net loss, when e.g. land clearing has been effected at an unmature 
stage of a timber stand, equals the difference between the expectation value and the realization value.

In this treatise, there are some interesting graphics e.g. on the relative use values of land alternatively to be cleared for agricultural purposes or retained in forestry, when the age of timber stands or the price of labour varies (pp. $62-63)$. The loss of forest production is largest if the land is taken into cultivation when the trees are in age classes $30-40$ years. The capital loss is then in the best site quality class and dense stand nearly $16000 \mathrm{Nkr} / \mathrm{ha}$ while in the third site class and less dense stands it is about $5000 \mathrm{Nkr} / \mathrm{ha}$. Agriculture cannot compensate such losses, and is competitive only where mature stands are removed, and the price of labour does not exceed $2 \mathrm{Nkr}$ per hour.

Among other recent studies, those of Ledje (1963) and Petrini (1964) in Sweden have brought forth interesting new aspects. Ledje uses data from the Sandby area in the Västland parish in Uppsala province for planning, in which linear and parametric programming are for the first time used. $\mathrm{He}$ introduces the afforestation of existing arable land as an alternative in his calculations, while annuities - computed from future forest returns using three alternative discount rates - are taken as comparable to gross margins (täckningsbidrag) in agricultural production. He presents calculations for three alternative farm sizes and three time periods of different lengths, representing to some extent also different levels of techniques and price ratios. In addition he takes the lease of additional arable land as a variable. In the parametric approach, the supply of capital is successively increased, which first extends the use of land for agricultural production up to leased areas, at a later stage diminishes it, even bringing arable land into afforestation, while the agricultural production tends increasingly to be transformed into utilization of purchased feeds (swine production). In this final stage, the calculations are scarcely interesting for our purposes. The comparison is between forestry and agricultural activities of a kind that do not require land resources.

An attempt by Ledje to use dynamic linear programming in the same study deserves special attention. Recognizing the need to adjust the plan to the predictable changes in the resources and to take into account the transfers of accumulated capital from one period to another, the author has applied this method to find optimum combinations for two or three successive periods. Limited possibilities to variance in the premises (conditions) have, according to the author, diminished the practical value of the results.

Petrini (1964) has in an interesting study tried to find out the views and supposed motives of Swedish farmers in regard to afforestation. As the economic motive, according to hypothesis, was predominant, a "normative study" to calculate the rational land use on eight selected farms in two areas (Halland and Hälsingland) was made, presuming several production alternatives and using linear programming. An optimal intensity level, approximately corresponding to the fourth highest among the farmers participating in the book-keeping accounts, is assumed for the calculation of the agricultural production. As to the forest production, the better half of the stand analyses, based on Yield Tables from the National Forest Survey and appropriate rotation periods, has been taken as the basis of calculation. 
The results of the normative study" indicate that the site class and the rotation period used in the afforestation calculations have considerable influence on the results. In the southern most region the afforestation opportunities are quite profitable if other conditions are favourable to this activity. In the lower part of northern Sweden, profitable afforestation situations occur very seldom. - "The afforestation is possible for the lowest layout classes under the assumptions of restricted labour access and high site classes even if there is complete uncertainty concerning the future labour opportunities outside the farm."

As in the study of Ledje, activities which do not require land resources prove to be perhaps excessively competitive in the use of labour and capital as compared to area demanding activities. This may be a consequence of a temporary disproportion between the product prices, and posibly also in the labour use coefficients. (In the former activities the economics of scale plays a larger role). In corporating these activities into the plan tends to cause confusion in the comparison of land use.

The "positiven study based on a questionnaire sent to 1421 farmers shows that nafforestation is not easily perceived in a situation of labour surplus on the farm. - Afforestation is only weakly related to the labour opportunities outside the farm, since this activity is regarded as a complement to farming by most farmers. - Longterm trends in the agricultural and forestry product prices seem to influence the afforestation" - (but there is) "a great uncertainty in the expectations of future price tendencies." - "The technical development and the development of agricultural wages seem to be most important."

The ndecision theoretical study", performed by Petrini, shows that the mexpectations of future tendencies in agriculture and forestry are not of great relevance for the afforestation decision - probably due to the fact that there are no prediction models for the estimation of future tendencies in technology and government policy."

When discussing future research projects Petrini states that where is - a great need to analyse in detail the computations in connection with the afforestation decision. To what extent, in which way, and in which situations, is the marginal principle used and understood by those owner-operators who have data for a relative comparison between land used for agricultural and forestry purposes." - These problems are the same that we are confronted with in our study, which mainly deals with decisions to change over land from forestry to agriculture.

The present writer has made comparisons of net returns and social income obtained by book-keeping farms in Finland from agriculture and forestry per areal unit (Pinkala 1965). He has also divided the social income into the components labour income, capital return and land rent following the principle that the distribultion should be done in proportion to the input units and prevailing market prices (wages, rate of interest ant market rent). Another member of our group has made some marginal calculations on the contributions of agriculture and forestry to the national product (HolopaInen 1967, pp. $99,100)$. 


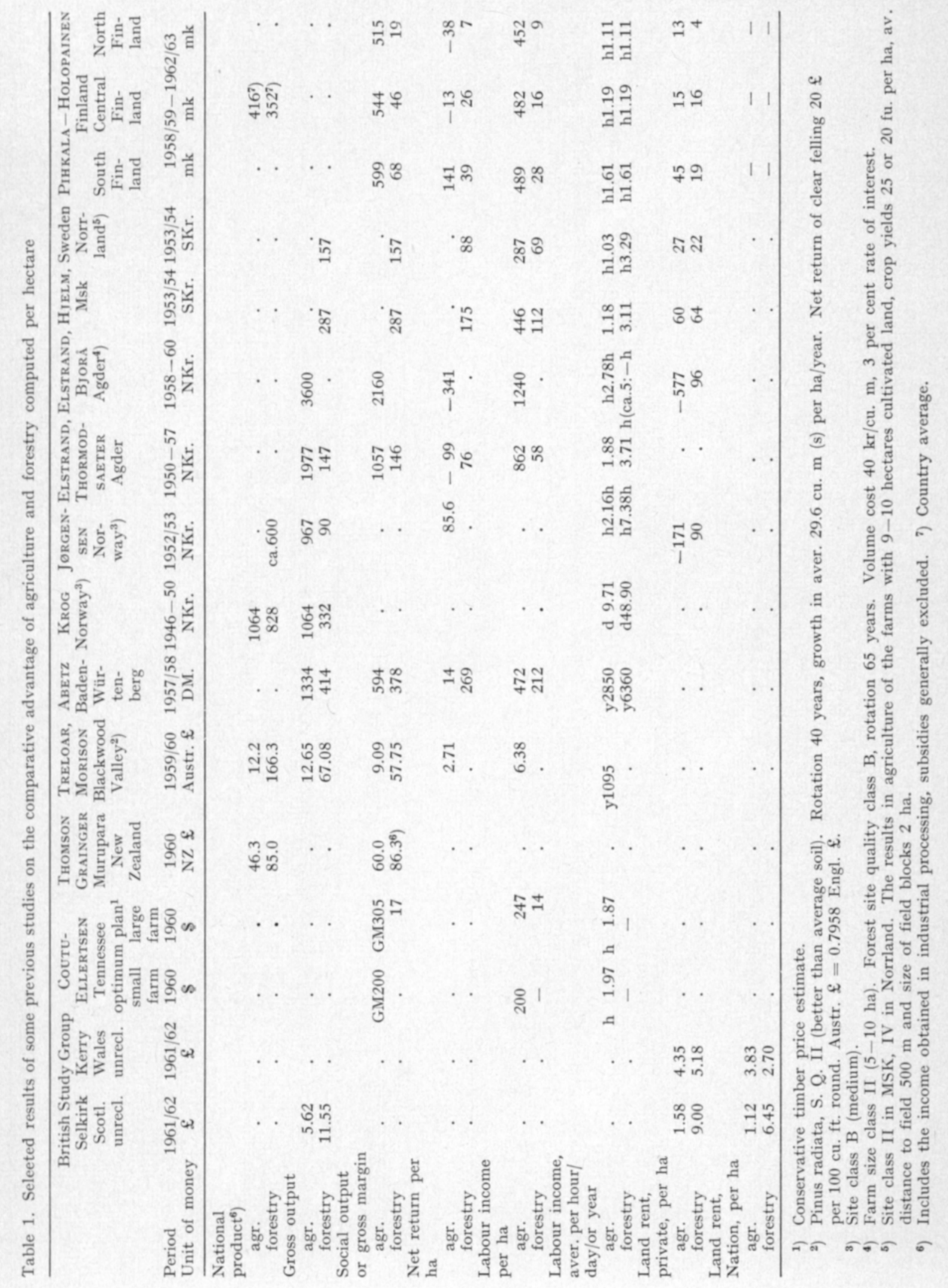




\section{Aim and scope of this study}

Decisions on land clearing, as well as on afforestation, are long-term decisions influenced by elements of uncertainty on future events and by time preferences of individuals. According to HEADY (1952, p. 382) wit is time considerations in production which give rise to the real difficulties in decision making». Comparisons of the alternative activities chosen through the decision are perhaps still more complicated, as the one activity, in this case agriculture, gives returns much sooner than the other, forestry, while the latter requires much less initial capital than the former. Another complicating factor is the greatly differing extent of employment offered by the alternative activities.

In the conditions that are of special interest in a country like Finland, the fact that most of the said decisions are made in family enterprises where agriculture and forestry are carried on with combined resources, constitutes a third complicating factor, especially since there are other types of firms, devoted to forestry and processing of forest products, again with combined resources.

Within the prevailing type of society, in which Government intervention of various kinds affects economic activity, there are further difficulties, since the decisions which are advantageous to private owners, may be less desirable from the point of view of society, i.e. of national economy.

Finally, there is a complication caused by the fact that agricultural production can be expanded by using increasing amounts of purchased feeds and other capital goods. It is doubtful whether in such cases it is justifiable to speak of a return to the land.

There are, moreover, difficulties which are mainly of a technical nature. In a country like Finland, where local soil types are varied and uneven, forming small figures, it is not easy to find forest and cultivated fields that are strictly comparable by natural conditions of growth. The management level not only of the fields, but also of the forests varies greatly and, for comparison purposes has to be considered very carefully. In addition reliable forecasting of production is undoubtedly one of the weakest points.

One can scarcely proceed from the hypothesis that all land now in agricultural use is directly comparable to the land covered by forests; generally the forests cover soil of lower quality. It may be more realistic to assume, that recently cleared land areas are comparable to the adjoining forest areas. But even this is not necessarily so since farmers naturally choose the sites for agricultural use among the better localities of their possessions. 
In the present study, the main interest is devoted to the following problems which are typical of situations where a decision relating to the transfer of a certain piece of land from forestry use to agricultural use has to be made.

(1) How to estimate the continuous (sustained) return from a technical unit of land to the owner, owner-occupier or the national economy, in alternative uses, on most common soil types and market situations. This comparison refers on an average to the period of a production cycle in forestry (rotation) and does not take into account changes in the economic unit;

(2) Should we estimate on the basis of factual results or to assume an optimum plan?

(3) What is the comparability of short term results, (e.g. within 10 or 20 years) in various situations, where e.g. the age and volume of the timber stands vary;

(4) The return to the investment eventually needed in connection with the transfer from one use to another;

(5) What advantages may be expected from the transfer if an optimum use of the resources within an economic unit is the ultimate aim.

It seems to the writer that the traditional approach, directed to estimate comparable land rents for both uses, is still the most advisable one, being more simple to understand and involving less complications than the comparisons of net discounted revenues. There is, admittedly, no difference in the ratios between the quantities indicated by these two methods of expression, provided that the same interest rate is used in discounting and capitalizing. In fact, often not only the agricultural, but also the forestry revenues, at least when the sustained yield principle has been followed, may in the long term calculations be estimated as being continuous and may even, as the agricultural revenue, favour a simpler expression. There exist, on the other hand, so many differences of opinion on the rate to be used in discounting, and what is even more important, on the applicability of the same rate of interest in capitalizing the short run income or discounting remote future incomes that presenting to the reader many alternatives of rates is always needed, and the confusion caused by chosing between them is left to the reader.

There are cases where the returns of single stands are rather continuous (un-even stands, Plenterwald), and land clearing is thus simply stopping the flow of forest income. Recent inventories of the tree stands of Finland, e.g., have indicated that especially the spruce stands have widely developed from the undergrowth of the older age classes (Mrкola 1966, pp. 4-7, 16). Though the cases where the selective cuttings are going on periodically in nearly equal quantities may be rare, these may also be taken into account when examining the situations which the decision maker has to meet. In such cases the discounting of future incomes has no special relevance.

But, it may be remarked, in most actual cases of land clearing, as well as afforestation, a choice must be made between immediate revenue from agricultural production or future revenue from forest. However, according to a widely held opinion among Finnish forest economists, the sustained yield principle applied in farm forests, allows some elasticity in the periodic fellings, so that e.g. the establishing of new plantations will soon justify larger yearly 
cuttings, while land clearing, which may temporarily increase the supply of timber, only gradually allows reduced cutting.

Whatever the case, the land rent can also be conceived as an annual payment (rental) which entitles to a future liquid asset (this is called annuity by BuTTRICK). ${ }^{1}$ ) One may imagine a market where securities granting future felling rights would be sold against annual payments. This rate would depend on the rate of discount and the prevailing opinion about the long-term development of timber prices and costs of felling, as well as in each single case, on the valuation of the growth and quality development of the stands.

If such a market existed, the individual decision maker could always compare the returns of both land uses in liquid from. The imperfections of the market could perhaps lead to erroneous annuity values: uncertainty would play an excessive role, but in principle, there would be no difference, as all cost calculations involve some uncertainty in price forecasts.

Although a market like this can scarcely be expected ever to become a reality, it is possible to imagine that a certain potential demand of such securities would arise not only on the part of the wood-working industries which would wish to guarantee the continuous flow of raw materials but also from pension funds and individuals who would be prepared to invest their money with full guarantee against inflation. On the potential supply side, on the other hand, would be the landowners whose preference for current income would be so strong that they would be ready to surrender their future income against a smaller present income. The price of time preference, i.e. the rate of discount, would then be determined for securities redeemable at different times by the supply and demand.

Irrespective of the absence of such a market, a valuation of the present value of a future income is in fact taking place, e.g. to the extent of credit that is demanded or granted against mortgages on forest growing pieces of land.

The traditional land rent approach does not, however, as shown in some contributions reviewed above, measure the other relevant dimensions of the comparison, viz. how to rate the share of other resources, labour and capital in the comparisons. The merits of both alternatives should in certain cases be judged, either by claiming high land rent and labour earnings to the worker simultaneously, or by relaxing the claim of high land rent in favour of labour income; or in some cases by regarding a low labour requirement as a merit. The alternatives may also be judged according to the rate of profit which accrues on investment, or, if capital is short, according to the need of investment or, if capital is short, according to the need of investment for a given level of income.

In many practical cases, the most advantageous use of land presupposes an optimum combination of land use for agriculture and forestry within an economic unit.

Since it appears that the problem of comparing the above land uses is a complicated one, and the finding of an answer of general applicability seems difficult, we shall now attempt to study cases of comparison.

\footnotetext{
1) Cí. Butrrick $\left(1943\right.$, p. 114). The formula of annual payment (AR) is $A R=\frac{\operatorname{Vn}(0.0 p)}{1,0 p^{n}-1}$,
were $\mathrm{Vn}$ is the value of a sum after it has been at interest for $n$ years, $\mathrm{p}=$ rate of discounting.
} 


\section{A field study on number of pioneer farms in four regions in Finland}

\section{Method used in the field study}

Some calculations on the comparative advantage of land clearing as an alternative in efforts to improve the food situation during the first post-war years were made by the present author. These calculations were submitted to the Board of Pellonraivaus Oy, and a Land Settlement Investigation Committee, but were not published. As statistical averages were used in the calculations, it seemed difficult to claim for them a high degree of reliability.

Since under the Land Settlement Programme, over 16000 so-called ncold farms" had been established, i.e. holdings which received their land almost exclusively in the form of forest or peat land, a study of the productivity of the newly-cleared land on these farms was suggested. It seemed probable that also the original character of the forest land taken into cultivation could be ascertained and thus comparable calculations could be made on the alternative uses.

After the financial means for a comparative study had been obtained, as mentioned in the preface, a study plan was made, in which the collection of primary data from three main areas representing differing climatical and market conditions was outlined. In each main area a few subareas were chosen, covering in most cases a group settlement area representing typical conditions, and in each subarea, a 50 per cent random sample was taken. In 1959 a hundred farms were thus selected in each main area, viz. in South Finland (SF) around Lahti-Kouvola-Heinola, in Middle Finland (MF) around Kuopio-IisalmiJoensuu, and in North Eastern Finland (NE) Salla-Kuusamo-Suomussalmi. Two years later, a fourth zone with again a hundred farms representing poor soils in Western Finland (W) around Ikaalinen-Parkano-Karvia was adopted as a study object. In this area the study farms lay more widely apart than in the others.

The North Eastern study area extends from $64^{\circ} 30^{\prime}$ latitude to $67^{\circ}$, and as climatic differences are rather large, it seems advisable to treat it as being divided into three subareas. These are, from South to North, Suomussalmi $(\mathrm{Ssm})$, Kuusamo $(\mathrm{Ku})$ and Salla $(\mathrm{Sa})$. The location of the main study areas as well as the above mentioned subareas is illustrated in the map of Finland in Fig. $1 .^{1}$ )

1) There are a few monographic descriptions of some subareas in our study (MEAD 1951, Ehlers 1968, Măki 1955, Kaukonen 1956, Pakkanen 1956, Rönty 1958). 


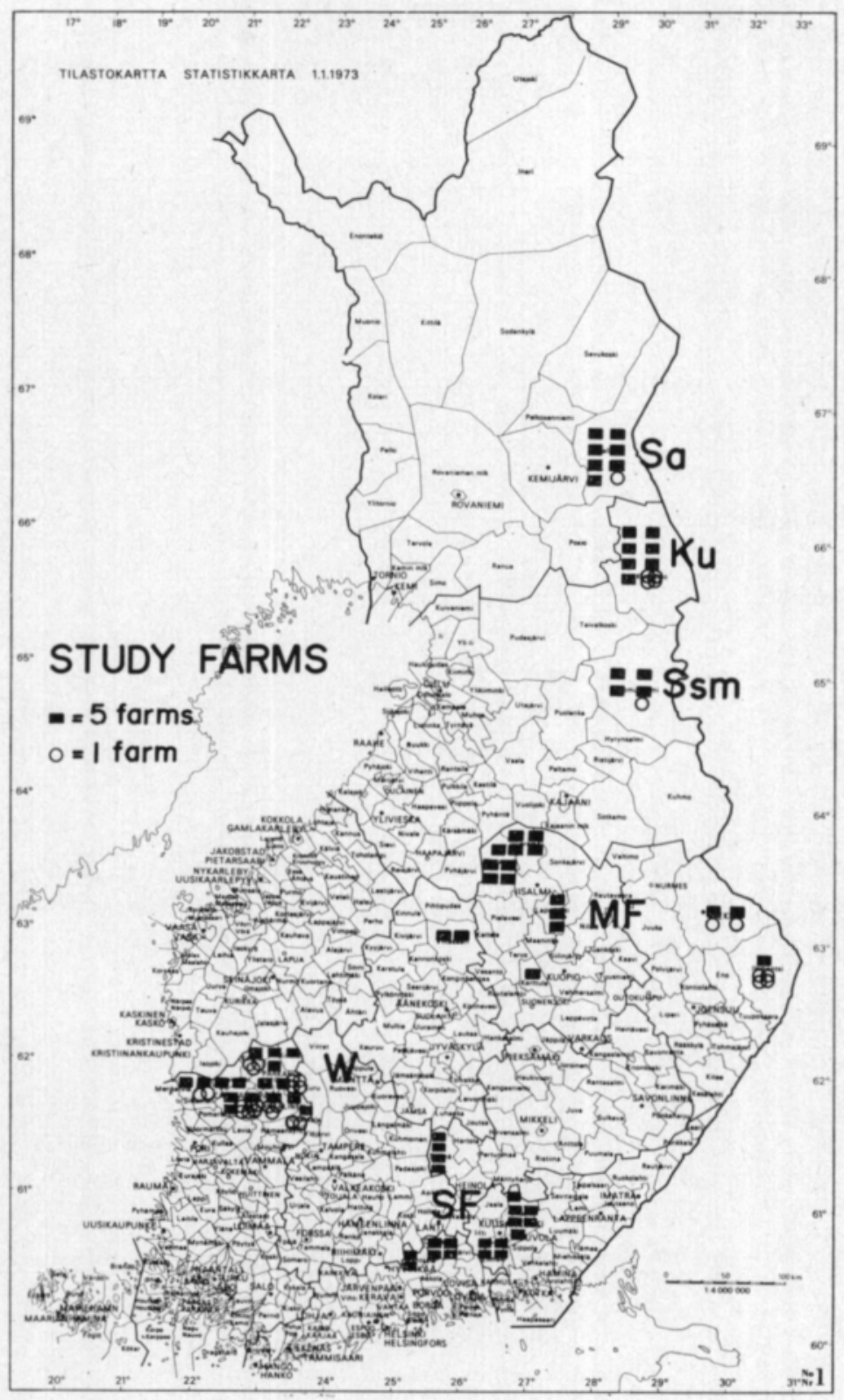

Fig. 1. Location of study areas.

It was hoped to find study areas representing typical pioneer farming areas, and farms with rather homogenous soil distribution. There were, however, relatively few cases, mainly in the SF main area, where only little variance in the soil type was discernible. In most areas there had been a tendency to provide the holdings with blocks of at least two types, mineral and peat soil. The maps of some subareas, reproduced in the mimeographed report, give some idea of the varying soil conditions. ${ }^{2}$ ).

2) Some maps are published by Lasola (1965). 
All the farms chosen in the samples were not willing to cooperate in the study. The non-attendance varied mostly between 5 and 15 per cent, but was during the first year in the NE area nearly 50 per cent and in MF in 1962 , as the result of a bad year, 40 per cent. In the NE area, a complementary enquiry was carried out in 1964 and the crop yields were recorded in this connection.

\section{The data on agricultural production}

A recording of crop yields and use of fertilizers and lime was organized on the study farms for a period of five years (1959-63), except in the lastmentioned main area, where records were kept only in 1961-63. The methods used in the crop estimation are described in detail by LAsolA (1965, pp. 45$49,119-123)$. Suffice it here to mention that grain and root crops as a rule were measured when stored, the hay crop was estimated counting the hay poles and weighing the hay of a sample of poles on the field. The objective method of crop estimation was applied in 1962 as a control, and in 1963 in most study areas as the only method. The cultivated areas reported upon by farmers were in principle checked by simple measurements; in 1962 field maps were drawn in cases where they were not previously available.

The yield of arable land used on pasture was, in the study of LAsola, estimated on the basis of records on pasturing days, milk production and supplemental food given. Observations on pasture yields, however, were possible only in about two thirds of the cases (LASOLA 1965, p. 101). There were further difficulties in dividing the yield between the whole-season pasture and the aftermath of hayfields, and in some cases of wood-land pastures. It therefore seemed advisable to estimate the pasturage in some other way, and particularly by assuming an equal fodder unit yield on the grasslands used for pastures and on those cut for hay. In addition the aftermath is taken into consideration when estimating the utilizable yields of hay-fields as well as the grazed areas. The aftermath is estimated at 30 per cent in Southern and Western areas, at 25 in the MF area and at 20 per cent in the NE area. The latter figures are based on some experiments reported by PoIJÄrvI (1934, pp. 120-121) and Pinkala and LAsola (1973, p. 385).

The total crop yield and the average yield per hectare were expressed in Scandinavian fodder units (f.u.). In the respective calculations straw, tops and other byproducts were included in the rate used in agricultural statistics.

The information on agriculture from study farms included also some data which facilitated the estimation of the animal production. No complete financial records were obtainable, and economic calculations were thus built on technical data and available information on prices.

\section{Some figures characterizing the land use and economic size of study farms}

The averages presented in Table 2 on the following page give an indication of the land resources of study farms, as well as of these farms as economic units. 
Table 2. Figures characterizing the average economic size of study farms.

\begin{tabular}{lcccccccccc}
\hline & $\begin{array}{c}\text { Farmer } \\
\text { family } \\
\text { size }\end{array}$ & $\begin{array}{c}\text { Arable } \\
\text { land } \\
\text { ha }\end{array}$ & $\begin{array}{c}\text { The total } \\
\text { crop f.u. }\end{array}$ & $\begin{array}{c}\text { Cattle } \\
\text { units }\end{array}$ & $\begin{array}{c}\text { Milk } \\
\text { cows }\end{array}$ & $\begin{array}{c}\text { Milk } \\
\text { deliveries } \\
\text { kg per } \\
\text { year }\end{array}$ & $\begin{array}{c}\text { Meadows } \\
\text { cleared } \\
\text { pasture } \\
\text { land ha }\end{array}$ & $\begin{array}{c}\text { Product- } \\
\text { ive } \\
\text { forest ha }\end{array}$ & $\begin{array}{c}\text { Unprod. } \\
\text { forest } \\
\text { land ha }\end{array}$ & $\begin{array}{c}\text { Waste } \\
\text { land ha }\end{array}$ \\
\hline SF & 4.4 & 8.95 & 16620 & 6.9 & 4.2 & 11317 & 0.78 & 14.42 & 1.01 & 0.65 \\
W & 5.5 & 6.13 & 9325 & 5.3 & 3.0 & 5733 & 0.25 & 39.86 & 4.15 & 5.74 \\
MF & 5.5 & 7.85 & 10520 & 6.1 & 3.6 & 6210 & 0.60 & 43.25 & 7.27 & 4.80 \\
NE & 6.9 & 5.56 & 8400 & 5.5 & 3.3 & 4548 & 4.10 & 104.44 & 33.81 & 57.29 \\
Ssm & 6.4 & 7.88 & 11270 & 6.5 & 4.4 & 9082 & 0.06 & 86.06 & 28.05 & 30.93 \\
Ku & 8.3 & 3.07 & 5235 & 4.2 & 2.7 & 4639 & 3.66 & 91.55 & 39.76 & 73.73 \\
Sa & 5.8 & 6.87 & 8875 & 5.7 & 3.9 & 7281 & 7.88 & 128.55 & 30.47 & 53.71 \\
\hline
\end{tabular}

According to the prevalent opinion, the average cultivated area of the study farms is below the optimum at least if agriculture forms the sole source of income; for their living the farmers evidently depend on forest returns and non-farm income. It is not possible to detect the exact economic results obtained on these farms; the data collected would not be sufficient any way. Instead the collected data should be used for calculations of a general application, where the available data of the Profitability Investigation of the Agricultural Economics Research Institute are used for completion. Relevant to this study are thus the crop yields and the inputs especially in the form of fertilizers and lime; as to the seed volume, standard values are used. There may be other inputs, improved seed, insecticides etc., as well as varying labour inputs in tilling, but in our opinion in the methods of cultivation, the average study farms scarcely differ from the level of progressive farms in their localities to such an extent that the different methods of cultivation would cause marked differences in hectare yields. The differences caused by the site quality and microclimatic variations, however, are noteworthy and relevant to this study.

\section{The main crops and the use of fertilizers and lime}

On the use of arable land for crops as well as on the crop yields in the main study areas, as well as in the three north-eastern subareas, data are presented in Table 3.

The pattern of cultivation in the southern and northern study areas is markedly different. Bread grain and other marketable crops become less significant when moving northwards; only barley and potatoes are supplementary to grassland in the North Eastern main area. Crop yields generally decline; crop failures are more frequent towards the north. The year 1962 was unfavourable in the whole country, but especially in the main areas of Middle Finland and the North Eastern area, where grain and potatoes gave only half or one third of the normal yield, or even less; 1964 was again unfavourable in North Finland. It should be noted, however, that the hayfields in the North Eastern area have given rather high yields, thanks to heavy doses of nitrogen fertilizer. The potato crops are in the North Eastern area on an average fully comparable with the crops in the main area of South Finland. 
Table 3. The percentage share of each of main crops of total arable area (A) and the crop yields per hectare, dt, or converted into f.u. (100) (B).

\begin{tabular}{|c|c|c|c|c|c|c|c|c|c|c|}
\hline & $\begin{array}{l}\text { Bread } \\
\text { grains }\end{array}$ & $\begin{array}{c}\text { Feed } \\
\text { grains }\end{array}$ & Potatoes & $\begin{array}{l}\text { Sugar } \\
\text { beets }\end{array}$ & $\begin{array}{l}\text { Gras } \\
\text { for hay }\end{array}$ & $\begin{array}{l}\text { sland } \\
\text { for past. }\end{array}$ & $\begin{array}{l}\text { Total } \\
\text { grassl. }\end{array}$ & Other & Fallow & Total \\
\hline \multicolumn{11}{|l|}{ A } \\
\hline SF & 15.0 & 27.5 & 2.0 & 1.4 & 38.4 & 11.7 & 50.1 & 2.1 & 1.9 & 100 \\
\hline W & 7.2 & 30.9 & 2.5 & 0.6 & 39.5 & 13.0 & 52.5 & 1.5 & 4.8 & 100 \\
\hline MF & 3.0 & 21.8 & 2.1 & 0.1 & 49.6 & 14.2 & 63.8 & 2.9 & 6.3 & 100 \\
\hline NE & 0.2 & 14.2 & 1.6 & - & 62.7 & 19.9 & 76.9 & 1.4 & - & 100 \\
\hline Ssm & 0.8 & 19.8 & 2.1 & - & 54.1 & 21.8 & 75.9 & 1.4 & - & 100 \\
\hline $\mathrm{Ku}$ & - & 19.9 & 2.1 & - & 68.7 & 7.9 & 76.6 & 1.4 & - & 100 \\
\hline Sa & - & 7.8 & 1.2 & - & 65.2 & 24.4 & 89.6 & 1.4 & - & 100 \\
\hline B & dt. & f.u. $\left.{ }^{1}\right)$ & dt. & dt. & dt. & f.u. $\left.{ }^{2}\right)$ & f.u. $\left.{ }^{3}\right)$ & $\begin{array}{c}\text { Fodder } \\
\text { gross }\end{array}$ & $\begin{array}{r}\text { units }^{4} \text { ) } \\
\text { net }\end{array}$ & $\begin{array}{l}\left.\text { f.u. } .^{5}\right) \\
\text { gross }\end{array}$ \\
\hline SF & 18.8 & 17.5 & 175.4 & 204.0 & 38.4 & 27.2 & 20.0 & 20.9 & 20.1 & 26.99 \\
\hline W & 12.6 & 14.3 & 146.1 & 133.6 & 39.1 & 22.5 & 20.3 & 17.4 & 16.7 & 23.87 \\
\hline MF & 13.8 & 13.2 & 138.6 & 84.0 & 34.1 & 12.7 & 17.1 & 15.4 & 14.6 & . \\
\hline NE & - & 10.3 & 143.7 & - & 45.3 & 17.8 & 17.4 & 17.8 & 17.4 & 22.62 \\
\hline Ssm & - & 14.5 & 154.5 & - & 42.0 & . & 20.2 & 18.3 & 17.7 & \\
\hline $\mathbf{K u}$ & - & 8.7 & 146.0 & - & 52.9 & . & 25.9 & 18.5 & 18.1 & \\
\hline Sa & - & 9.7 & 134.9 & - & 40.7 & . & 19.5 & 17.1 & 16.8 & \\
\hline
\end{tabular}

1) not including straw.

2) Estimate of LAsola (p. 101).

${ }^{3}$ ) Estimate where aftermath is included and yield of pasture assumed to be equal to that of cut hayfield.

4) Including straw, tops etc,. not incl. pasture or aftermath.

5) The fodder unit yields of the book-keeping farms (under 10 hectares) of the Profitability Investigation are presented for comparison.

The figures in Table 4 indicate the volumes of plant nutrients in fertilizers and lime used for crops and cultivated pasture, in average per hectare, 1959$\left.63 .{ }^{2}\right)$ The value of plant nutrients per hectare, according to the prices paid at delivery points, is shown in the last column.

Table 4. The use of plant nutrients in fertilizers and lime on the study farms, $\mathrm{kg}$ per hectare.

\begin{tabular}{|c|c|c|c|c|c|}
\hline & $\begin{array}{l}\text { Nitrogen } \\
\mathrm{N}\end{array}$ & $\begin{array}{l}\text { Phosphorus } \\
\qquad \mathrm{P}_{2} \mathrm{O}_{5}\end{array}$ & $\begin{array}{l}\text { Potassium } \\
\mathrm{K}_{2} \mathrm{O}\end{array}$ & $\begin{array}{l}\text { Lime } \\
\mathrm{CaO}\end{array}$ & $\begin{array}{l}\text { Value of plant } \\
\text { nutrients }{ }^{1} \text { ) }\end{array}$ \\
\hline 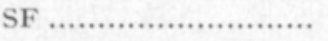 & 32 & 54 & 28 & 72 & $75: 57$ \\
\hline W & 21 & 32 & 27 & 117 & $54: 66$ \\
\hline 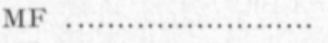 & 31 & 38 & 28 & 69 & $65: 30$ \\
\hline 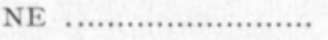 & 60 & 66 & 89 & 32 & $127: 96$ \\
\hline Ssm ......................... & 63 & 72 & 94 & 14 & $134: 93$ \\
\hline Ku ....................... & 62 & 76 & 100 & 67 & $141: 39$ \\
\hline 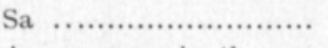 & 57 & 53 & 76 & 17 & $115: 74$ \\
\hline $\begin{array}{l}\text { Average use in the } \\
\text { country } \ldots \ldots \ldots \ldots \ldots \ldots\end{array}$ & 22.2 & 37.3 & 27.1 & . & . \\
\hline
\end{tabular}

1) In West Finland area 1961-63, in NE in most cases 1960-64.

$\left.{ }^{2}\right)$ Here, as well as in later calculations, the new Fmk, $(1 \$=3: 22)$, according to the exchange rate of 1963 , is used. 
It is interesting to note that the use of plant nutrients in fertilizers has in all study areas, except Western Finland, been larger than the average in the whole country. The figures on the North Eastern area are unexpectedly high heavy fertilizing, especially of grassland, is, however, a fact on study farms, which in this respect are on a much higher intensity level than the average farms in these regions. (Also the hay crop yield is about $10 \mathrm{dt}$ higher.)

For economic calculation it would be important to know to what extent the used average doses of fertilizers correspond to the requirement for getting optimum economic results of respective agricultural production.

LASolA $(1965$, pp. $102-107,167)$ tried to examine the relation of crop yields and fertilizer inputs on the study farms, using the multiple regression analysis. A distinct positive correlation was found in SF and W between the volume of plant nutrients and crop yields in f.u., this was rather distinct also in the MF area; in the NE study area the results are somewhat unclear. The method is prabably not suitable for estimating the production function of fertilizer inputs. ${ }^{1}$ ) Other evidence shows that e.g. the hay crops of North Finland peat soils vary greatly irrepective of fertilizing (VALMARI 1957 a, pp. 18-33; PuUstJärvi 1959, pp. 88-90).

\section{The marketable crop and its value}

In Table 5, based mainly on figures presented in Table 3, the net crops of bread and feed grain, as well as of potatoes, are computed, subtracting the normal use of seed (rye $170 \mathrm{~kg}$, spring wheat $260 \mathrm{~kg}$, barley $220 \mathrm{~kg}$, oats $200 \mathrm{~kg}$, potato $2700 \mathrm{~kg}$ per hectare), and calculated per hectare of cultivated farm area. In this table the quantities are presented in fodder units. There is also an estimate on the value of the marketable crop. In this calculation are used the producer prices of regions covering the study areas, over the economic years 1959/601963/64 (Appendix I). An exception is made regarding potatoes, the cultivation of which on the study farms is mainly for family consumption. The quantities corresponding to the consumption figures observed by the Rural Consumption Investigation 1959/60 have been priced according to the retail prices recorded by the Bureau of Social Research, an average for 1959-63, while only the rest has been rated as per producer prices.

1) E.g. WEINSCHENCK (1966, p.93) stresses the danger of shybrid production functions, as well as the difficulty of quantifizing the climatic factor should this be used as an independent variable. 
Table 5. The marketable crop from arable land, by main study areas, per total area of cultivated land (incl. pasture), (A) quantity in fodder units, (B) value in mks per ha.

\begin{tabular}{|c|c|c|c|c|c|c|c|}
\hline & SF & W & MF & NE & Ssm & Ku & $\mathrm{Sa}$ \\
\hline \multicolumn{8}{|l|}{ A } \\
\hline Bread grain .............. & 218 & 77 & 32 & - & 8 & - & - \\
\hline Feed grain.............. & 388 & 393 & 218 & 120 & 195 & 124 & 45 \\
\hline Potatoes ................... & 50 & 60 & 70 & 34 & 42 & 46 & 20 \\
\hline \multirow[t]{2}{*}{ Sugar beet $\ldots \ldots \ldots \ldots \ldots$} & 57 & 23 & - & - & - & - & - \\
\hline & 713 & 553 & 320 & 154 & 245 & 170 & 65 \\
\hline \multicolumn{8}{|l|}{$\mathbf{B}$} \\
\hline Bread grain .............. & $102: 24$ & $38: 92$ & $15: 01$ & - & - & - & - \\
\hline Feed grain ............... & $129: 98$ & $130: 31$ & $71: 72$ & $36:-$ & $58: 50$ & $37: 20$ & $13: 50$ \\
\hline Potatoes ................... & $34: 53$ & $33: 04$ & 49:17 & $31: 44$ & $30: 36$ & $48: 87$ & $21: 60$ \\
\hline \multirow[t]{2}{*}{ Sugar beet .................. } & $27: 65$ & 9:89 & - & - & - & - & - \\
\hline & $294: 40$ & 212:09 & $135: 90$ & $67: 44$ & $88: 86$ & $86: 07$ & $35: 10$ \\
\hline
\end{tabular}

\section{The data on milk production}

No complete data on the animal production of the study farms could be obtained. However a number of milk herds kept records for milk herd recording associations. As practically all the farms regularly sent most of their marketable milk to comparatively few large dairies, relatively reliable data for the estimation of this highly important market product were available for the study. Regarding other animal production there were less data.

To complete these figures, the farm consumption of milk and direct sales to the consumers had to be estimated. For the former, the figures of the Rural Consumption Investigation $(1959 / 60)$ on the annual consumption of farmer families in four regions (South Finland, Middle Finland, Ostrobothnia and North-East Finland), are available. If adjusted to the family size of the study farms in proportion with the number of family members, the estimated milk consumption figures of $1376,1720,1665$ and $2249 \mathrm{~kg}$ (for the main study areas $\mathrm{SF}, \mathrm{W}, \mathrm{MF}$ and $\mathrm{NE}$, respectively) can be used. The direct sales to consumers were estimated using figures from agricultural statistics.

There may be, to a smaller extent, also consumption of home produced butter, and small quantities of cheese. Using the figures of the Rural Consumption Investigation, with similar adjustments as used for milk, the estimated volumes of home butter would be $4.3,5.5,16.9$ and $23.5 \mathrm{~kg}$ per farm, respectively.

Using the data on milk deliveries with the above mentioned complementary estimates, the following figures of milk production may be presented (Table 6). The figures of study farms which are members of the milk recording associations, and the regional averages of the associations are also tabulated.

From the figures it appears that some differences exist in the milk production per cow between the main study areas. These differences may to some extent affect the net values of the non-marketable crops. A special calculation, as stated below, has been made on this item. 
Table 6. Data on milk deliveries, estimate of milk production of the study farms, total and per cow, and average milk production per cow within milk recording associations and the Profitability Investigation farms of regions most closely covering the study areas, $\mathrm{kg}$.

\begin{tabular}{|c|c|c|c|c|c|c|c|}
\hline & \multirow[t]{2}{*}{ SF } & \multirow[t]{2}{*}{ W } & \multirow[t]{2}{*}{ MF } & \multirow[t]{2}{*}{ NE } & \multicolumn{3}{|c|}{ Subareas } \\
\hline & & & & & Ssm & Ku & Sa \\
\hline Aver. No. of cows .... & 4.22 & 2.96 & 3.61 & 3.31 & 4.43 & 2.74 & 3.87 \\
\hline Yearly deliveries of & & & & & & & \\
\hline milk, kg ................... & 12486 & 6489 & 7019 & 6709 & 10692 & 4639 & 7281 \\
\hline Home use of milk, kg & 1376 & 1720 & 1665 & 2249 & 2087 & 2705 & 1890 \\
\hline $\begin{array}{l}\text { Home use of butter, } \\
\text { in milk equiv., kg ...... } \\
\text { Direct sales of milk, }\end{array}$ & 106 & 132 & $(405)$ & $(564)$ & - & . & - \\
\hline $\begin{array}{l}\text { Direct sales of milk, } \\
\text { kg }\end{array}$ & 647 & 350 & 422 & $(405)$ & $(405)$ & 342 & 300 \\
\hline Computed prod. kg ... & 14615 & 8691 & 9511 & 9927 & 13748 & 8250 & 10035 \\
\hline $\begin{array}{l}\text { Computed prod. per } \\
\text { cow, } \mathrm{kg} \ldots \ldots \ldots \ldots \ldots \ldots \ldots . .\end{array}$ & 3463 & 2936 & 2635 & 2999 & 3103 & 3010 & 2593 \\
\hline $\begin{array}{l}\text { Av. of milk recording } \\
\text { study farms, } \mathrm{kg} . \ldots . . . . . \\
\text { Av. of milk rec. }\end{array}$ & 3922 & 3426 & 2763 & 3408 & 3501 & 3671 & 3199 \\
\hline $\begin{array}{l}\text { associations, } \mathrm{kg} . . . . . . . \\
\text { Av. of bookkeeping }\end{array}$ & 4268 & 3860 & 3650 & 3097 & 3206 & 3380 & 2987 \\
\hline farms, $<10$ ha, $\mathrm{kg} \ldots$ & 3859 & $\left(\begin{array}{l}3 \\
587\end{array}\right)$ & 3413 & 3188 & . & . & . \\
\hline
\end{tabular}

Complementary to the milk production on the study farms, especially in the regions where milk is used for the manufacturing of butter, there is beef production, by feeding calves for shorter or longer periods, using skim milk and other non-marketable feeds, and also production of pork, thus utilizing the skim milk and non-marketable root crops. Since pigs as well as sheep are of rather small significance on these farms, the beef production is used in the following calculations. ${ }^{1}$ ) The data from the study farms on the sales and home slaughter of young cattle are, however, fragmentary; only a rather sketchy estimation is therefore possible, based on the available skim milk and the surplus of non-marketable crops, after the normal feed requirement of the existing horses and milk cows has been filled.

The estimation of beef production will be made after the feed requirement of draft animals has been computed.

\section{Draft animals}

The data on draft animals include the yearly numbers of adult and young horses, and for all main areas except $W$ more or less complete records on the horse days in farm and forest work, as well as off-farm work, in 1963. The use of grain and non-marketable feeds, necessary for feed balance calculations, must be estimated approximately on the basis of the number of adult horses. The other data facilitate estimation of the gross returns of agriculture, which

1) In a special study concerning the Suomussalmi subarea (PiнкALA ja Lasola 1973), these lines are also followed. 
also includes the value of horse days in forest and off-farm work, and are useful when estimations of costs of agricultural production are made.

Table 7. presents the average number of adult horses on study farms, and in the group of book-keeping farms with less than 10 hectares arable land, in the comparable regions of the Profitability Investigation (TSMK 1964, p. 32). There is also an estimate of the normal requirement of horsedays in the study farm forests, assuming continuous fellings, according to the principle of sustained yield; the actual use of horse days in the agriculture and forestry, as well as off-farm working days of a sample of study farms are also indicated.

Table 7. Average numbers of horses and tractors per farm and hectare cultivated land on the study farms and on the I and II size class farms of P. I.; and work days or hours of horses and tractors.

\begin{tabular}{|c|c|c|c|c|c|c|c|}
\hline & \multirow[t]{2}{*}{ SF } & \multirow[t]{2}{*}{ w } & \multirow[t]{2}{*}{ MF } & \multirow[t]{2}{*}{ NE } & \multicolumn{3}{|c|}{ Subareas } \\
\hline & & & & & Ssm & $\mathrm{Ku}$ & $\mathrm{Sa}$ \\
\hline \multicolumn{8}{|l|}{ No. of adult horses } \\
\hline $\begin{array}{c}\text { study farms, } \\
\text { per farm } . . . \ldots \ldots \ldots \ldots \ldots . . . . . . . . . .\end{array}$ & 0.75 & 0.64 & 0.68 & 0.43 & 0.51 & 0.33 & 0.57 \\
\hline per ha ......................... & 0.09 & 0.12 & 0.10 & 0.09 & 0.08 & 0.12 & 0.11 \\
\hline \multicolumn{8}{|l|}{$\begin{array}{l}\text { book-keeping farms, per ha } \\
\text { size class }\end{array}$} \\
\hline I $(<10$ ha $) \ldots \ldots \ldots \ldots$ & 0.11 & \multicolumn{2}{|c|}{0.11} & 0.10 & - & - & - \\
\hline II $(10-25$ ha) ............ & 0.06 & \multicolumn{2}{|c|}{$\underbrace{0.06}$} & 0.06 & - & - & - \\
\hline No. of tractors per farm ......... & 0.60 & . & 0.26 & 0.48 & 0.50 & 0.48 & 0.46 \\
\hline \multicolumn{8}{|l|}{ Horse days, per farm } \\
\hline agriculture $\ldots \ldots \ldots \ldots \ldots \ldots \ldots \ldots . . . . . . . . . .$. & 47 & . & 57 & 18 & 25 & 8 & 23 \\
\hline 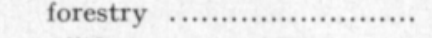 & 16 & . & 21 & 20 & 26 & 11 & 35 \\
\hline off-farm & 9 & . & 19.3 & 1.9 & 0.5 & 0.1 & 3 \\
\hline hired ............................... & 1.3 & . & - & - & 1.8 & 1.8 & 4 \\
\hline \multicolumn{7}{|l|}{ Tractor hours, own tractor, } & 155 \\
\hline hired tractor .......................... & 16 & . & 28 & 13 & 13 & 11 & 15 \\
\hline own tractor, off-farm ............. & 26 & . & 44 & 72 & 39 & 43 & 125 \\
\hline $\begin{array}{l}\text { Estimated normal requirement } \\
\text { in forest, horse days per farm }\end{array}$ & 16 & 10 & 21 & 20 & 20 & 20 & 20 \\
\hline
\end{tabular}

The majority of the study farms (approximately 2/3) still use horses in field work and forests. The number of adult horses is, however, smaller per hectare than on the book-keeping farms of the same size class. Most of the farms that use horses in daily work, hire tractors for ploughing and other heavy work. Some of the smallest farms have neither horse nor tractor, while some larger have both. The varying number of horses is taken into account in the cost calculations. 


\section{Estimate of beef production}

According to special calculations presented in Appendix II, three main alternatives for feeding calves are economical: feeding them up to $100-120$ $\mathrm{kg}$ slaughter weight, to $235 \mathrm{~kg}$ in 24 months using small quantities of skim milk and respectively more grain, or (based on experiments in the MF-region), to $167 \mathrm{~kg}$ in 19 months, with liberal use of skim milk, small quantities of grain and an effective use of pasture during two seasons. In the two first alternatives up to $700 / 900 \mathrm{~kg}$ skim milk is used, in the third $1520 \mathrm{~kg}$, while hay, silage and pasture are required in the respective alternatives in 340,2 134 and 1428 fodder units. On the basis of these figures it may be computed that per 100 f.u. of non-marketable crops, $32 \mathrm{~kg}$ slaughter weight in the first, $11 \mathrm{~kg}$ in the second and $11.7 \mathrm{~kg}$ in the third case can be produced. Provided that there has been no purchases of baby calves for feeding - which at the time was not common in Finnish agriculture - the production of beef has been limited mainly by the number of calf births and by calf mortality. If the number of potentially surviving calves can be estimated at 80 per cent of the number of cows, the quantity of non-marketable feed per cow utilized in raising calves may be limited, with regard to skim milk in alternative 1) to $760 \mathrm{~kg}$, in alternatives 2) and 3) to 544 and $1217 \mathrm{~kg}$ per cow. In conditions where most of the marketed milk is processed to butter, there is evidently a surplus of skim milk, and thus a chance for pork production or milk powder manufacture. The non-marketable crop utilized in beef production is, respectively, limited to 272, 1707 and 1142 fodder units per milk cow.

Assuming that 80 per cent of the volume of whole milk delivered to dairy plants can be returned as skim milk, the quantities given in the second row of Table 2, Appendix II, are available for beef production. The production of beef can then be estimated in a way which is explained in Appendix II. It will be seen that there is more skim milk than the minimum requirement for beef production.

\section{The non-marketable crop and its utilization}

In Table 5 the data of crops and an estimate of the value of the marketable part of these have been presented. In the following table, the remaining, nonmarketable crop is calculated, taking into account the aftermath of hay-fields, as well as the estimated amount of fodder units obtained from pasture, and an attempt is made to estimate its distribution in animal production.

The use of non-marketable crops for horses has been estimated on the basis of the figures from 76 farms presented in the Profitability Investigation of the economic year 1961/62 (TSMK 1964, p. 32). The estimation for milk cows is based on the average fodder consumption figures of the milk recording herds within the regions of some Agricultural Societies covering, as far as possible, the study areas (TSK 1962, pp. 46-50). As these data are classified at $500 \mathrm{~kg}$ intervals, interpolation has been used to find values corresponding to the average milk production of study farms. These values, as well as the inter- 
Table 8. The non-marketable crop and its utilization according to an estimation based ou normal fodder requirements, f.u. per hectare cultivated land.

\begin{tabular}{|c|c|c|c|c|c|c|c|}
\hline & \multirow[t]{2}{*}{ SF } & \multirow[t]{2}{*}{ W } & \multirow[t]{2}{*}{ MF } & \multirow[t]{2}{*}{ NE } & \multicolumn{3}{|c|}{ Subareas } \\
\hline & & & & & Ssm & Ku & Sa \\
\hline Total net crop, incl. aft. \& past. & 2106 & 1808 & 1566 & 2007 & 2003 & 2162 & 1958 \\
\hline marketable ...................... & 713 & 553 & 320 & 154 & 245 & 171 & 65 \\
\hline non-market. . ................... & 1393 & 1255 & 1246 & 1853 & 1758 & 1991 & 1893 \\
\hline Thereof fed to horses ............. & 167 & 208 & 174 & 156 & 128 & 214 & 166 \\
\hline milk cows .......................... & 927 & 904 & 830 & 1104 & 1058 & 1681 & 1042 \\
\hline rest ................................. & 299 & 143 & 242 & 593 & 572 & 96 & 685 \\
\hline
\end{tabular}

polated values of grain and oil cake consumption, are presented in the lower part of the table.

Subsequently an estimation of the use of non-marketable fodder is made on the per hectare basis, taking into account the cultivated pasture area. When the fodder units for horses and milk cows are subtracted from the non-marketable crop, there remains a rest item, which according to our hypothesis, is utilized for young cattle (Appendix II). Ignoring in this connection cattle raising for the renewal of the stock, we regard this fodder utilization as being for beef production.

\section{Value of agricultural production}

On the basis of the computed results presented in the tables and using the prices referred to in Appendix I, the following estimate of the value of agricultural production per hectare of cultivated land is made. This estimate is comparable to the gross return figures of the Profitability Investigation provided that the value of marketable products utilized in animal production is deducted from the total sums. In this case it has been assumed that the quantity of feed grain, if smaller than the above estimated requirements for horses, milk cows and beef production, is wholly utilized in animal production, and its value is thus not included in the gross return. Meanwhile, the difference hetween the requirements and home production is assumed to be bought feed grain.

Table 9. Estimated production of milk, horse days (outside agriculture) and beef, and requirement of marketable grain and oil cakes for feeding, per ha.

\begin{tabular}{|c|c|c|c|c|c|c|c|}
\hline & \multirow[t]{2}{*}{ SF } & \multirow[t]{2}{*}{ W } & \multirow[t]{2}{*}{ MF } & \multirow[t]{2}{*}{ NE } & \multicolumn{3}{|c|}{ Subareas } \\
\hline & & & & & Ssm & $\mathbf{K u}$ & Sa \\
\hline Milk, $\mathrm{kg} \quad \ldots . . .$. & 1633 & 1418 & 1212 & 1785 & 1745 & 2687 & 1460 \\
\hline 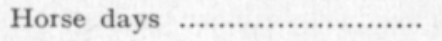 & 1.8 & 1.6 & 2.7 & 3.6 & 3.3 & 5.4 & 3.8 \\
\hline 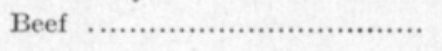 & 54 & 51 & 54 & 61 & 71 & 31 & 80 \\
\hline \multicolumn{8}{|c|}{ Requirement for feeding } \\
\hline Grain, horses ...................... & 26 & 33 & 28 & 24 & 21 & 34 & 26 \\
\hline cows ........................... & 376 & 299 & 193 & 234 & 213 & 356 & 179 \\
\hline , beef ........................... & 37 & 60 & 44 & 22 & 18 & 45 & 9 \\
\hline Oil cakes ............................ & 15 & 29 & 19 & 8 & 12 & 56 & - \\
\hline
\end{tabular}


Table 10. Value of agricultural production per hectare cultivated land (including pasture), value of grain required for feeding and estimated purchases of grain and oil cakes (mk/ha).

\begin{tabular}{|c|c|c|c|c|c|c|c|}
\hline & SF & W & MF & NE & Ssm & Ku & Sa \\
\hline Marketable crop.................... & 295 & 208 & 136 & 67 & 88 & 86 & 35 \\
\hline thereof for feeding ................. & 130 & 127 & 72 & 36 & 58 & 37 & 13 \\
\hline Milk .................................. & 547 & 473 & 410 & 680 & 635 & 1067 & 558 \\
\hline Horse days, in forestry ......... & 30 & 27 & 46 & 75 & 67 & 110 & 83 \\
\hline 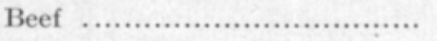 & 148 & 128 & 132 & 220 & 209 & 91 & 219 \\
\hline Cow subsidies ....................... & - & - & 5 & 28 & 26 & 41 & 26 \\
\hline 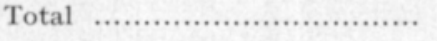 & 890 & 710 & 657 & 1034 & 967 & 1358 & 908 \\
\hline \multicolumn{8}{|l|}{ Estimate of purchases of } \\
\hline 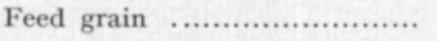 & 20 & 2 & 13 & 61 & 27 & 114 & 61 \\
\hline Oil cakes à -:55, per f.u. ........ & 15 & 10 & 16 & 36 & 40 & 64 & 34 \\
\hline
\end{tabular}

\section{Method of cost estimations}

According to the study plan, the estimation of most cost items was to be carried out without complete book-keeping records, which it was not possible to obtain. The regional averages of the Profitability of Agriculture Investigations of the economic year $1961 / 62$, and especially the figures of the two smallest size classes, have been used as a comparable basis. Figures on fertilizer and lime costs are based on observations, already referred to on p. 313 , while on the quantities and values of the concentrates used only estimates referred to on pages $319-320$ are available. There was some information on buildings, livestock and machines which could be based on the 1959 Census data, and additional information was collected from the economic year 1962/63, on the working days of the farmer and his family, on the use of tractors and horses in agriculture and forestry as well as in off-farm work. ${ }^{1}$ )

In respect to the current costs (maintenance, depreciation and interest) caused by earlier investments, the movable (and realizable capital is in principle separated from real property; the costs caused by the former are included in the variable costs of tractive power, animal production etc. To facilitate marginal calculations, the costs of buildings and fixtures are estimated as another group. As to the land no estimations on value are made here, as land rent in our calculations is the rest item.

There are current costs which must partly be paid in money, and partly involve reductions of potential product sales. In addition to fertilizers and lime, and bought concentrates referred to above, gasoline, fuel, wood and eletricity, oil, materials used e.g. in plant protection and conservation of fodder are among these costs, while veterinary help, artificial insemination, herd control etc. also belong to the former group, and the value of the home produced fodder

1) The Census figures of family labour have not been utilized in this study as it is not feasible to separate the work in households and investments from current farm work. 
for draft animals to the latter. The costs of the latter group are not deducted from the gross return figures as the corresponding value is not included in these figures.

\section{Cost of tractive power and field machinery}

As the Profitability Investigation is based on the single-entry book-keeping system, it is difficult to estimate the total costs of draft animals and other tractive power from the regional averages of this source of information. More detailed calculations of the costs of horses are, indeed, available from 76 farms (TSMK 1964, p. 60), but, as the value of the work production is taken into account only in forestry and off-farm work, it is not appropriate to include the cost of feeding and some other min naturan items in the farm costs.

Thus, only the depreciation and interest of horses and equipment, as well as expenses for veterinary service, shoeing etc. are included in the cost estimation of draft animals. Costs of a tractor are in the Profitability Investigation included in a group where combines and motor vehicles are also represented, and monetary expenses consist not only of costs of fuel, but also of payments for hired machines. As most study farms which use horse power often hire tractors and vice versa, and as the average number of horses per hectare on the study farms in most areas does not essentially differ from the averages of I size class book-keeping farms, the computed cost figures may be fairly comparable. The costs of other machinery include the expenses for repair and depreciation, as well as interest. The interest of movable capital is computed at 5 per cent.

Table 11. Cost of tractive power and machines in field work, siqe classes I and II, mk/ha.

\begin{tabular}{|c|c|c|c|c|c|c|}
\hline & \multicolumn{2}{|c|}{ SF } & \multicolumn{2}{|c|}{$\mathrm{W}+\mathrm{MF}$} & \multicolumn{2}{|c|}{ NE } \\
\hline & I & II & I & II & I & II \\
\hline \multicolumn{7}{|l|}{ Horses } \\
\hline 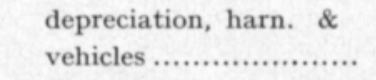 & 9.04 & - & 8.20 & - & 10.06 & - \\
\hline interest harn. \& vehicle & 3.41 & 2.40 & 3.22 & 2.90 & 3.29 & 2.52 \\
\hline interest, horse capital & 3.03 & 1.74 & 3.21 & 1.85 & 2.90 & 1.79 \\
\hline money expenses .......... & 2.15 & - & 2.29 & - & 2.08 & - \\
\hline \multicolumn{7}{|l|}{ Tractors, combines etc. } \\
\hline fuel .......................... & 14.48 & 15.30 & 8.02 & 14.86 & 9.08 & 13.49 \\
\hline hires ....................... & 13.15 & 11.17 & 12.28 & 7.94 & 10.68 & 7.29 \\
\hline deprec. \& repairs ...... & 23.71 & 31.07 & 13.81 & 28.39 & 20.54 & 24.03 \\
\hline interest $5 \% \quad \ldots . . . \cdots \cdots$ & 7.10 & 11.49 & 5.44 & 10.73 & 8.88 & 9.21 \\
\hline \multicolumn{7}{|l|}{ Other machines } \\
\hline deprec. \& repairs ...... & 26.80 & 24.90 & 20.80 & 23.58 & 19.14 & 19.51 \\
\hline interest $5 \% \quad \ldots \ldots \ldots \ldots . .$. & 10.10 & 8.21 & 8.12 & 7.90 & 6.26 & 6.77 \\
\hline
\end{tabular}




\section{Some cost items of livestock production}

Monetary expenses, excluding those for purchases of concentrates and mineral feeds, are here estimated using data from the special calculations on livestock production of the Profitability Investigation (TSMK 1964, p 61.). These are e.g. payments for veterinary services, artificial insemination and herd control. Further, the costs of fuel and electricity, the depreciation and repair costs of barn machinery, and that part of the depreciation of livestock capital, which is involved in estimates connected with inventories. As our calculations for milk production do not take into account the feed and work used for heifers, an additional item, depreciation of milk cows, is here introduced. It is composed of labour costs and of the value of baby calf and feeds; the housing costs are included elsewhere; and the net cost is obtained by subtracting the value of discarded cows. ${ }^{1}$ )

\section{Cost of investment in buildings}

The building activity on the study farms was directed to a few standard types, among these two types were predominant on farms that were full time colonization farms. According to the investigation of a Committee appointed in 1949 to assess the results of settlement activities (Kom. miet. 1957, p. 51), the measures and building cost estimates of these types were as follows (the cost figures are from 1954, but will here be used in deflated 1961 values):

\begin{tabular}{lcccccc}
$\begin{array}{l}\text { Type of } \\
\text { building }\end{array}$ & $\begin{array}{c}\text { Volume }\left(\mathrm{m}^{3}\right) \\
\text { warm }\end{array}$ & of space for & \multicolumn{3}{c}{ Estimate of building costs, mk } \\
part & cold part & no. cows & cattle & units & 1954 & 1961 \\
1. & 478 & 732 & 9 & 16 & 17960 & 23096 \\
2. & 236 & 555 & 5 & 9 & 10080 & 12963
\end{tabular}

Most of the study farms had no other economy buildings (the dwelling house and the sauna have not been included in the calculations). The above mentioned volumes were, in fact, sufficient for the livestock as well as for the required fodder. Although particularly in Southern Finland there are at times separate sheds or drying barns, there are many reasons for using the building values given here.

In the following, the costs of maintenance are estimated at 1.5 per cent, those of depreciation at 3 per cent and insurance at 0.2 per cent of the said values. ${ }^{2}$ ) The interest claim has been provisionally fixed at 3 per cent, which

1) The feed costs are calculated assuming the use of $200 \mathrm{~kg}$ milk, $1000 \mathrm{~kg} \mathrm{skim} \mathrm{milk,} 290$ f.u. grain and 1820 non-marketable feed, priced respective by $-: 34,-: 04,-: 35$ and $-: 20$, totalling 576:66 under 26 months raising period. A calf is priced 50:- and 130 labour hours at 2:32 cost 301:60. From the total cost the value of a slaughtered cow, $150 \mathrm{~kg}$ at $2: 52$, is subtracted, and when a 15 per cent renewal of the herd is assumed, a yearly cost per cow of 83 : - is obtained. In this $45: 24$ is the price of labour and the rest net return to the feed.

$\left.{ }^{2}\right)$ These percentages are within the margins which are recommended in some Finnish farm management manuals. 
has been calculated from half of the amount of establishing costs. It has been assumed that average study farms manage with type 2, but in the marginal calculations, where extended cultivation is assumed, the cost figures are based on type 1 .

The figures in Table 12 are calculated by dividing the total yearly costs of buildings by average cultivated areas; alternative 2, however, applies the upper limit stipulated by the colonization authorities for State supported settlement farms (15 hectares arable land). For comparison, the figures of the Profitability Investigation (TSMK 1964, p. 53) referring to the depreciation and repairs are presented, however, reduced in such a way, that a part corresponding to the value of dwelling houses in relation to the total value of buildings is subtracted.

Table 12. Estimated yearly costs of the economy buildings, and comparative figures from the Profitability Investigation (mk/ha).

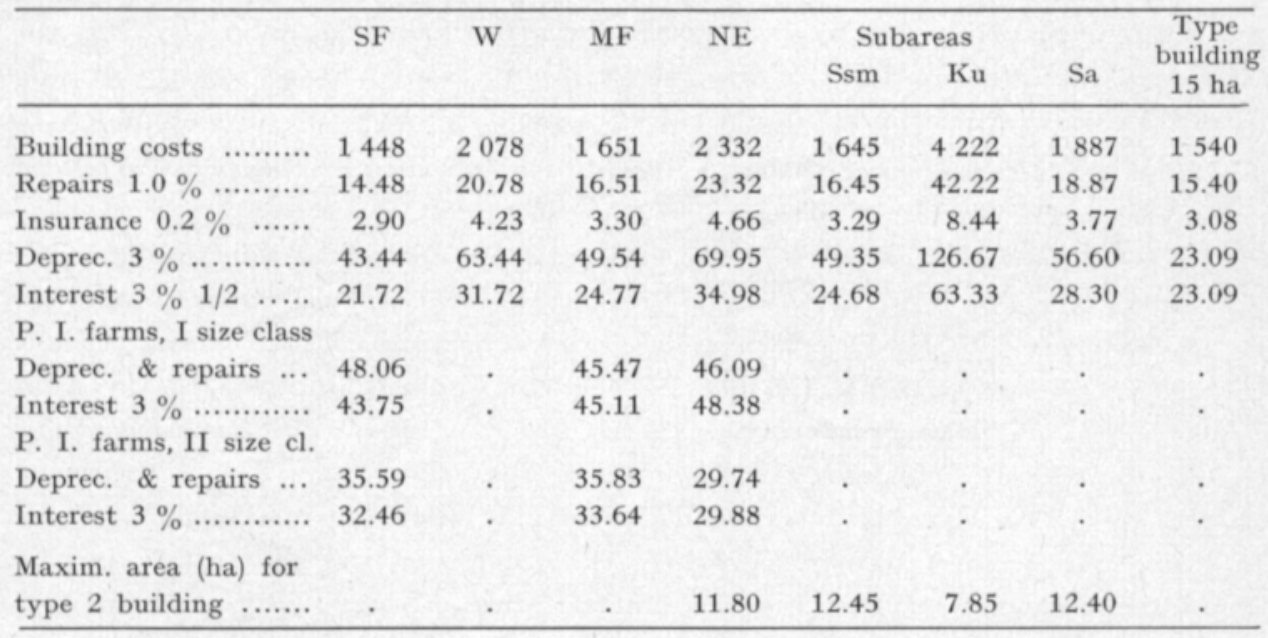

\section{Cost of labour}

Regarding the quantity and cost of human labour which is one of the most important items, satisfactory information was not obtainable. As the input of human labour is dependent on the intensity of production, combination of productive activities and the mechanization level, the data of the Profitability Investigation must be judged in view of the similarity of the study farms and the comparable group. It seems that the book-keeping farms have obtained larger yields per hectare (p. 313) and have in most areas more cows, but in regard to mechanization are nearly (p. 317) on the same level. On the other hand, there is evidence that there is some overestimation of family labour hours, probably because too large a part of the labour days of the women is credited to the care of livestock. ${ }^{1}$ )

1) Furthermore, the maintenance and repairs of buildings and machinery are included in the figures of the Profitability Investigation. According to the to some extent outdated figures of SipIL. A (1946, pp. 364-373) the working hours for these were 32 per hectare, while storage and miscellaneous work took 43 hours, on farms with a cultivated area below 15 ha 
In our computations, the varying structure of production and the economics of scale should also be somehow taken into account. Unfortunately the only empirical studies on the use of work time for different crops and care of animals, published by SIPILÄ $(1946,1949)$ are greatly out of date, and cannot be utilized without corrections. The standards recommended by agricultural economists are at present generally prepared by adding the normal work time requirements of successive stages of operations, allowing some waste time for every stage. Such standards may be practical in this study, as we wish in the first place to find out the work time in the pricing of the working time.

Within the limits of variation in farm size, there is scarcely any reason to differentiate the standards according to farm size; standards presented by Westermarck and Melén $(1962$, pp. 32, 51) for farms with less than 10 hectares of arable land have therefore been used as such. (Appendix V). For comparison, the labour use is computed also according to the Danish standards, where two alternatives (a) for horse driven, (b) for tractor using techniques are available (Håndbog, pp 44-53). Regarding the care of horses and young cattle the standards are also used in the original form. As, however, the number of milk cows per farm differs considerably in the study areas, and the economics of scale is most distinct in this line of production, we have estimated the labour input per cow in herds of different sizes. An approximation for differentiating, practical also in the application of linear programming, is included in the Danish standards, which allow for the care of livestock 760 man hours per year irrespective of the number of cows, and in addition 62 man hours per cow and year. As is apparent in Appendix IV, the figures computed on the basis of the information of SIPILÄ $(1949$, p. 42) and SANDQvist $(1963$, p. 42) follow approximately the same pattern, although they indicate a higher degree of labour use. We have used standards which give about 40 man hours per cow above the rounded numerical values obtained when applying the Danish recommendations. ${ }^{1}$ ) The figures of labour input applied in our calculations, computed per hectare of arable land on the basis of the data of each study area, are presented below; the averages of the Profitability Investigation, and the figures computed directly by the Finnish and Danish standards are presented for comparison.

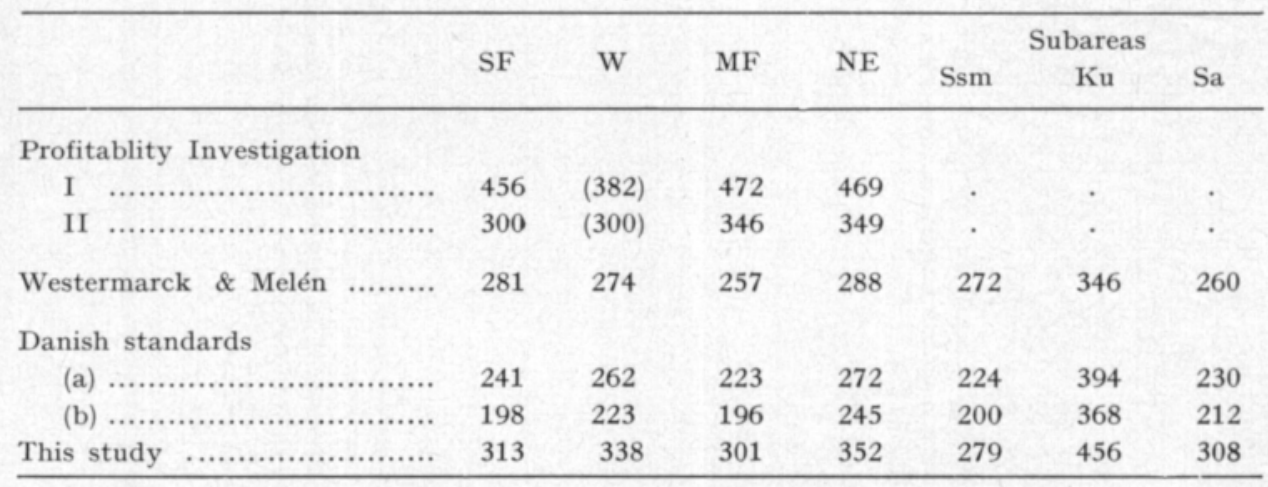

1) The approximate level of Finnish standards is thus attained. 
The problem of pricing the labour hours has been solved here simply by applying the opportunity cost, i.e. the wages of rural industrial workers. According to Iнамuотіla $(1968$, pp. 99,110$)$ male workers were paid iв the rural districts where prices of necessities were lowest, in the period 1959/601963/64 an average of 2: 32 per hour, while the labour income of the cultivators of book-keeping farms was in size class I 1: 05 and size class II 1: 21 per hour (manual work only). The target, the corresponding opportunity price, is certainly not reached, as will be seen in the following.

There would be more reason to determine the price of labour at a lower level, e.g. using the wages of agricultural workers as the basis. In the Profitability Investigation, for the book-keeping year 1961/62 (TSMK 1964 p, 26), the average price of hired farm worker was 1: 38 for man hour, 1: 06 for woman hour and 0:69 for child hour. The average value of converted family work hour, when the female and the children hours are multiplied by 0.8 and 0.5 , was on the farms of I size class the following: South Finland 1: 42, Middle Finland 1: 40 and North East Finland 1: 39. These values include the estimated compensation for managerial efforts. As alternative 2, these prices for labour are applied.

There is no settled market price for farm family labour, unless we choose to accept the minimum average labour income which is supposed to maintain the majority of farmers in their occupation - providing we had the means to estimate it and its trend values.

\section{Balance of return and costs}

In Table 13, the results of previous estimations are collected together to give and idea on the economic advantage of land use for agricultural production on study farms. In Table 14 the summarised results are presented to facilitate the drawing of conclusions.

As can be seen, the taxable net return, if labour is paid according to the opportunity price, is negative in most cases. Land rent is negative to an even larger extent when interest on capital and labour are paid according to market rates. The labour, however, does not generally receive remuneration that would correspond to the opportunity price.

There is some similarity between these computed averages and those published in the Profitability Investigation. The taxable net returns and the social output in the periods $1958 / 59-1962 / 63$ were in the size class I of bookkeeping farms the following (values deflated into the 1963 price level, cf. Рінкаla 1965, pp. 40, 47, 51).

Taxable net return

Southern region

Social output

Price of labour, per hour

56
730
$1: 45$

1:45

$\begin{array}{cc}\begin{array}{c}\text { Central } \\ \text { region }\end{array} & \begin{array}{c}\text { North Eastern } \\ \text { region }\end{array} \\ -62 & -108 \\ 593 & 534 \\ 1: 40 & 1: 39\end{array}$


Our study farms in Southern, Western and Middle Finland have not been as remunerative as the book-keeping farms similar in size, as they consist mostly of previously established small farms. But in the comparisons of taxable net returns it should be remembered that the estimated labour use and the pricing of labour have been different. In the NE area the study farms seem to be reasonably comparable to the old book-keeping farms.

A study on a number of Middle and North Finland pioneer farms, made by the Central Union of Agricultural Societies in cooperation with Pellonraivaus Oy $1952-59$, is also interesting as comparison (Tutkimustulokset ... 1959 , p. 22). In this study, the average taxable net return was $-70: 09 \mathrm{mk} / \mathrm{ha}$, the social output was $327: 78$, and the remuneration to labour 0:74 per hour. Average size of the farms was 8.21 ha arable land, 53.1 ha productive and 22.0 ha low quality forest land.

Table 13. Summary of cost items by study areas, mk/ha

\begin{tabular}{|c|c|c|c|c|c|c|c|}
\hline & SF & W & MF & NE & Ssm & $\mathrm{Ku}$ & Sa \\
\hline Fertilizers \& lime ................ & 76 & 55 & 65 & 128 & 135 & 141 & 116 \\
\hline Bought concentr. ................. & 42 & 26 & 53 & 96 & 63 & 185 & 93 \\
\hline , seed $\ldots \ldots \ldots \ldots \ldots \ldots \ldots \ldots$ & 9 & 8 & 8 & 7 & 7 & 7 & 7 \\
\hline \multicolumn{8}{|l|}{ Tractive power \& machines } \\
\hline money expenses .................. & 27 & 23 & 23 & 24 & 24 & 24 & 24 \\
\hline deprec \& repairs $. . . \ldots \ldots . . .$. & 60 & 43 & 43 & 50 & 50 & 50 & 50 \\
\hline 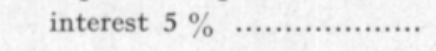 & 23 & 20 & 20 & 21 & 21 & 21 & 21 \\
\hline \multicolumn{8}{|l|}{ Livestock } \\
\hline money expenses ............... & 20 & 21 & 20 & 27 & 22 & 37 & 21 \\
\hline fuel, electr. . ................... & 8 & 9 & 8 & 11 & 9 & 15 & 9 \\
\hline litter ........................... & 5 & 6 & 5 & 6 & 5 & 9 & 5 \\
\hline depr., milk cows .............. & 18 & 18 & 17 & 22 & 21 & 34 & 21 \\
\hline depr. \& repairs, utens. ....... & 7 & 6 & 6 & 6 & 6 & 6 & 6 \\
\hline interest $5 \%$.................. & 17 & 19 & 17 & 23 & 19 & 33 & 19 \\
\hline Insurance ........................... & 8 & 7 & 7 & 11 & 11 & 11 & 11 \\
\hline \multicolumn{8}{|l|}{ Buildings } \\
\hline repairs ......................... & 14 & 21 & 16 & 23 & 17 & 42 & 19 \\
\hline deprec. .......................... & 43 & 63 & 50 & 70 & 49 & 127 & 57 \\
\hline interest $3 \%$................. & 22 & 32 & 25 & 35 & 25 & 63 & 28 \\
\hline Labour, priced $2: 32 / \mathrm{hr} . ~ . . . \ldots . . .$. & 726 & 784 & 698 & 817 & 647 & 1058 & 715 \\
\hline thereof heifers for mainten. & 21 & 22 & 21 & 27 & 25 & 40 & 25 \\
\hline Current expenses .................. & 196 & 155 & 189 & 310 & 276 & 429 & 286 \\
\hline Repairs \& depr. .................. & 142 & 151 & 132 & 171 & 143 & 259 & 153 \\
\hline Interest .............................. & 62 & 71 & 62 & 79 & 65 & 117 & 68 \\
\hline
\end{tabular}


Table 14. Balance of return and costs of agricultural production, mk/ha

\begin{tabular}{|c|c|c|c|c|c|c|c|}
\hline & SF & W & MF & NE & Ssm & $\begin{array}{l}\text { Subar } \\
\text { Ku }\end{array}$ & $\mathrm{Sa}$ \\
\hline Gross return ......................... & 902 & 734 & 680 & 992 & 967 & 1358 & 908 \\
\hline \multirow{3}{*}{$\begin{array}{l}\text { Current money expenses, } \\
\text { incl. insurances ................... } \\
\text { Costs of variable capital, } \\
\quad \text { deprec., repairs ................. } \\
\quad \text { interest } 5 \% \text {................... }\end{array}$} & 196 & 155 & 189 & 310 & 276 & 429 & 286 \\
\hline & 66 & 49 & 49 & 56 & 56 & 56 & 56 \\
\hline & 40 & 39 & 37 & 44 & 40 & 54 & 40 \\
\hline 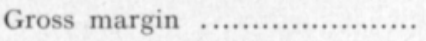 & 610 & 488 & 402 & 648 & 616 & 841 & 566 \\
\hline Fixed capital rep. \& depr. .... & 58 & 84 & 66 & 93 & 66 & 169 & 76 \\
\hline interest $3 \%$................... & 22 & 32 & 25 & 35 & 25 & 63 & 28 \\
\hline Social output ....................... & 592 & 443 & 373 & 599 & 590 & 726 & 530 \\
\hline \multirow{2}{*}{ 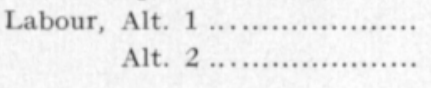 } & 726 & 784 & 698 & 817 & 647 & 1058 & 715 \\
\hline & 444 & 473 & 421 & 489 & 388 & 634 & 428 \\
\hline \multicolumn{8}{|l|}{ Taxable net return } \\
\hline Alt. 1 .................... & -174 & -380 & -362 & -264 & -99 & -388 & -227 \\
\hline Alt. 2 ................... & 108 & -69 & -86 & 64 & 160 & 36 & -60 \\
\hline \multicolumn{8}{|l|}{ Remuneration to land } \\
\hline Alt. 1 ................... & -236 & -451 & -424 & -343 & -164 & -505 & -295 \\
\hline Alt. 2 .................... & 46 & -140 & -148 & -15 & 95 & -79 & -50 \\
\hline $\begin{array}{l}\text { Remuneration to labour, with } \\
\text { no land rent }\end{array}$ & 490 & 333 & 273 & 474 & 483 & 554 & 420 \\
\hline \multicolumn{8}{|l|}{$\begin{array}{l}\text { Remuneration to labour, with } \\
\text { no land rent neither interest to }\end{array}$} \\
\hline fixed capital ........................ & 512 & 365 & 298 & 509 & 507 & 616 & 448 \\
\hline Per farm, mk ..................... & 4582 & 2237 & 2339 & 2830 & 3995 & 1891 & 3078 \\
\hline Per working hour ................. & 1.70 & 1.12 & 1.02 & 1.48 & 1.91 & 1.42 & 1.51 \\
\hline No. of work hours ................ & 2695 & 1989 & 2299 & 1916 & 2087 & 1330 & 2033 \\
\hline
\end{tabular}

\section{The data on forestry}

The main aim of this study is to compare alternative uses of types of land that are most commonly taken into cultivation. Consequently, not only the average forestry production but especially that of land that had been cleared or was going to be cleared in future for agriculture has been studied. In the following, the available data on the total forestry potential of the study farms will be presented.

There is a great deal of variation in the forests of the study farms, not only between the main areas but also between individual farms and within the boundaries of single farms. The site quality, density of trees and age class distribution, as well as the earlier management varies greatly, and the available for this study were also very heterogeneous. Thus, e.g. the information on the site quality was in some study areas scanty or totally lacking, and only in a few areas had data on the age structure and state of the timber stands been collected in advance. 
For additional information, the forests of 31 farms were in $1960-61$ cruised by using mainly a combined line and circle method. These farms were chosen by two-stage random sampling mainly from farms of the SF and MF areas. The original plan was to take measurements on $\mathbf{5 0}$ farms, but there were doubts about their relevance to the study, especially in the NE area, where most of new cultivations had been established on unproductive peat soils. From the Suomussalmi subarea, relatively satisfactory material was obtained from recent forest plans.

The collected information comprises first the division of forest areas into site types, which, according to the method introduced by CAJANDER (1909) and used in National Forest Inventories, is based on the surface vegetation. In Table 15 the average distribution of the study farm forest areas is presented in columns marked with (a). These figures are compared with the averages computed by M. Ilvessalo (1962, p. 119) from the forests of all colonization farms (b), those of the nearest State forest administrative districts (c), LinNAMIES (1959,pp. 168-169) and all forests by Forestry Board Districts (d).

As the study farms were established in most cases on State or corporate forests, which consist of less than average fertile soil types, it seems natural that the best site types are represented with lower than average percentages, and that there is some similarity in the distribution of site classes between the study farms and State forests. Especially in Western Finland and Middle Finland areas the two most fertile site classes are underrepresented as compared with all forests of the regions. The less productive mineral soil site types are, especially in the Western study area, predominant on study farms, and swampy soils, spruce peat, in natural condition near in productivity to the VT site class, and pine swamp, which is much less productive, are more frequent within most MF study areas.

In the NE study areas comparisons are more difficult and the recent change in the classification system complicates matters further. A high percentage of pine swamps with low tree growth seems, however, to be characteristic of study farms.

In Table 16, the age structure of timber stands is presented from the SF and MF study areas and Kuusamo subarea, with comparisons to all colonization farms in South and Middle Finland (M. Ilvessalo, 1962 p. 125) and State forests (Linnamies, 1959 pp. 178-181). It is evident that the age division of the study farms is less regular than on all colonization farms. In the SF area the age classes under 40 years are underrepresented, in the MF area the most represented age class is that of $21-40$ years. The few observations made in the NE area indicate a very limited occurrence of age classes from 40 to 100 years, while older classes (up to $140-160$ years) are heavily represented. This is characteristic also of North Finland State forests.

The volume and value growth of the forest is related to the site quality and the growing stock, its density, age structure and tree species. Estimations on timber stand and growth were made on the basis of material collected by cruising the study farm forests.

According to the original plan, the information of the forest site type and timber stand of the land now under cultivation had to be collected partly from 
Table 15. The distribution of productive forest land in to soil forest site types.

\begin{tabular}{|c|c|c|c|c|c|c|c|c|c|c|c|c|}
\hline & \multicolumn{4}{|c|}{ Southern Finland } & \multicolumn{3}{|c|}{ Western Finland } & \multicolumn{5}{|c|}{ Middle Finland } \\
\hline & a & b & c & d & a & c & d & a & b & c & d & e \\
\hline OM $\quad \ldots . \cdots \cdots \cdots \cdots \cdots \cdots$ & 17.7 & 21.1 & 12.4 & 33.5 & 3.1 & 3.1 & 9.7 & 2.6 & 9.2 & 1.0 & 13.8 & 18.6 \\
\hline 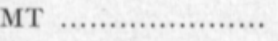 & 37.4 & 35.3 & 35.1 & 36.7 & 9.1 & 8.2 & 34.4 & 21.6 & 34.7 & 21.1 & 36.6 & 49.2 \\
\hline VT, EVT ............ & $(16.7)$ & 21.3 & 28.3 & 18.0 & 38.0 & 39.7 & 29.4 & (32.1) & 23.4 & 41.1 & 26.3 & \\
\hline CT, ECT, HMT ...... & $(3.6)$ & 4.4 & 6.2 & 1.0 & 34.0 & 29.1 & 4.8 & $(3.0)$ & 2.9 & 8.1 & 3.2 & 18.2 \\
\hline Spruce peat .......... & 11.4 & 6.6 & 7.0 & 6.1 & 7.6 & 3.0 & 6.5 & 17.8 & 14.8 & 12.6 & 11.1 & 6.1 \\
\hline Pine peat ............. & 0.3 & 3.1 & 2.4 & 1.4 & 8.2 & 11.3 & 6.7 & 8.5 & 4.6 & 9.2 & 4.1 & 3.6 \\
\hline Drained peat ....... & 11.2 & 8.2 & 8.6 & 3.4 & - & 8.1 & 8.2 & 14.4 & 10.4 & 6.4 & 5.0 & 4.3 \\
\hline
\end{tabular}

\begin{tabular}{|c|c|c|c|c|c|c|c|c|c|}
\hline & \multicolumn{3}{|c|}{ Suomussalmi } & \multicolumn{4}{|c|}{ Kuusamo } & \multicolumn{2}{|c|}{ Salla } \\
\hline & $\left.a^{1}\right)$ & c & d & a & c & d & $\left.d^{2}\right)$ & a & c \\
\hline OMT $\ldots . . \ldots \ldots \ldots \ldots \ldots$ & - & 0.3 & 1.4 & - & 1.5 & 0.9 & 0.9 & - & 1.4 \\
\hline MT $\ldots \ldots \ldots \ldots \ldots \ldots \ldots$ & 10.3 & 35.4 & 12.0 & $\left.35.7^{2}\right)$ & 19.9 & 7.6 & 7.1 & - & 7.0 \\
\hline VMT ….................. & - & - & 35.8 & - & - & 1.9 & 2.8 & 5.4 & \\
\hline VT, EVT ........... & 52.5 & 33.4 & 18.1 & 27.0 & 23.2 & 28.5 & 31.5 & 28.0 & 22.3 \\
\hline EMT $\ldots \ldots \ldots \ldots \ldots \ldots$ & - & 4.4 & 1.0 & - & 30.2 & 29.5 & 31.3 & 35.7 & 26.0 \\
\hline Hмт .................. & - & 1.4 & 0.4 & - & 3.8 & 8.1 & 5.3 & 28.5 & 20.8 \\
\hline CT, ECT .............. & 4.5 & 5.3 & 4.0 & - & 0.4 & 0.2 & 0.2 & 1.5 & 0.4 \\
\hline ErClT, ClT .......... & - & 2.7 & 1.0 & - & 5.2 & 10.1 & 6.8 & - & 9.3 \\
\hline Spruce peat ......... & 7.2 & 9.7 & 11.1 & 14.3 & 6.9 & 5.9 & 6.9 & - & 7.4 \\
\hline Pine peat ............ & 25.5 & 6.9 & 8.5 & 21.6 & -8.8 & 6.8 & 8.9 & - & 5.3 \\
\hline Drained peat ......... & - & 0.5 & 2.4 & 1.4 & 0.1 & 0.4 & 1.0 & - & 0.1 \\
\hline
\end{tabular}

a) Available averages of the study farms.

b) The averages of colonization farms cruised in Forest Inventory 1951-53 (M. ILvESSALO, p. 119). The $\mathrm{SF}$ region indicated here is larger than in this study and includes also the W-area. NE is not represented. (Ibid., p. 111).

c) Averages of nearest State Forest; SF districts named Keski-Häme, Tammela, Uusimaa, Tammisaari; W Parkano, Karvia; MF Viitasaari, Iisalmi, Rautavaara, Lieksa, Ilomantsi; NE Suomussalmi, Kuusamo, Salla (Linnamies 1959, pp. 168-169).

d) Averages of all forests of Forestry Board Districts covering study areas, according to Forest Inventory $1951 / 53$.

e) Average on ssmall farms" of Osara-ILvessalo study.

Southern half mineral soil site types:

OMT = grove, Oxalis-Myrtillus type

MT = Myrtillus type

VT $=$ Vaccinium type

CT = Calluna type

ClT = Cladina type

$\mathrm{K}=$ Spruce peat

$\mathbf{R}=$ Pine peat

1) Old classification

${ }^{2}$ ) Includes also pMT, VMT, HMT
Northern half mineral soil site types (new system):

GMT = Geranium-Myrtillus type

pMT = northern Myrtillus type \ sometimes

pMT = northern Myrtillus type $\int$ combined

VMT = Vaccinium-Myrtillus type to MT

HMT $=$ Hylocomium-Myrtillus type

EMT = Empetrum-Myrtillus type

EVT = Empetrum-Vaccinium type

ErClT = Ericaceae-Cladina type

ClT = Cladina type 
Table 16. The distribution of forest into age classes, study farms (a), all colonization farms (b) and nearest State forests (c), in MF also Osara-Ilvessalo study farms (d).

\begin{tabular}{|c|c|c|c|c|c|c|c|c|c|c|c|c|c|}
\hline \multirow{2}{*}{\multicolumn{2}{|c|}{ Age classes }} & \multicolumn{3}{|c|}{ SF } & \multirow{2}{*}{$\begin{array}{l}\mathrm{W} \\
\mathrm{c}\end{array}$} & \multicolumn{4}{|c|}{ MF } & \multirow{2}{*}{$\begin{array}{l}\text { Suomus- } \\
\text { salmi } \\
\text { c }\end{array}$} & \multicolumn{2}{|c|}{ Kuusamo } & \multirow{2}{*}{$\begin{array}{l}\text { Salla } \\
\text { c }\end{array}$} \\
\hline & & a & b & c & & $\mathrm{a}$ & b & c & d & & $\mathbf{a}$ & c & \\
\hline open & & 0.7 & - & 0.8 & 1.3 & 6.3 & - & 2.5 & 1.5 & 0.3 & 2.0 & 0.1 & 1.9 \\
\hline $1-20$ & years & 5.5 & 5.9 & 6.9 & 10.6 & 11.1 & 2.6 & 6.2 & 10.1 & 2.2 & 11.3 & 0.6 & 0.1 \\
\hline $21-40$ & , & 8.1 & 15.7 & 10.5 & 10.8 & 24.1 & 12.4 & 12.1 & 15.8 & 3.2 & 10.0 & 4.4 & 2.7 \\
\hline $41-60$ & , & 19.5 & 28.8 & 11.9 & 18.7 & 15.8 & 21.1 & 8.0 & 20.7 & 4.1 & 4.3 & 3.2 & 2.3 \\
\hline $61-80$ & , & 34.5 & 30.3 & 17.1 & 17.6 & 16.9 & 27.6 & 11.5 & 20.6 & 10.0 & 3.0 & 3.2 & 1.1 \\
\hline $81-100$ & , & 18.3 & 13.9 & 21.5 & 24.6 & 9.8 & 22.5 & 17.3 & - & 20.3 & 1.0 & 10.2 & 3.1 \\
\hline over 100 & 0 & 13.3 & 5.4 & 31.3 & 16.4 & 16.3 & 14.2 & 42.4 & 24.3 & 59.9 & 71.7 & 78.4 & 88.8 \\
\hline
\end{tabular}

documents and maps of the colonization authorities, and partly by observations along the boundary lines of plots taken into cultivation. Within the three main study areas (W and part of the NE area excepted) the outlines of the existing fields were drawn on maps where the soil types could be read; the attempts to find out the forest site class and the timber stands from earlier documents failed in most cases, however. In the summer of 1963 boundary line observations were therefore made in the SF, W and MF main areas.

The observations on the forest sites and soil types were made in this connection. The structure of the timber stands was judged by classification into standdevelopment classes, a method introduced by OSARA (1948) for forest inventories (cf. Davis 1966, p. 146). Only such cases were studied where the boundary area belonged to the same pattern of the map and probably had the same kind of vegetation as the cultivated area before its clearance. There were only limited possibilities to make observations of this kind, especially in such main areas where the farm fields were to a great extent joined together; while in others where the farms lay scattered among the woods, observations were easier to make. The most favourable conditions were found in the Western main area.

The development class of timber stands was often not determinable as the boundary area was either cut down or treated in some way. The forest type, on the other hand, could be determined in most cases.

Most of the observations were made in the Middle Finland main areas. All farms except those where the total forest area had been cruised in $1960-61$ were visited in the Southern, Middle and Western main areas. Observations on forest type and development class applied to the following areas (ha):

\begin{tabular}{|c|c|c|c|c|c|c|}
\hline & & & $\begin{array}{l}\text { No of } \\
\text { farms }\end{array}$ & $\begin{array}{c}\text { Forest } \\
\text { type }\end{array}$ & $\begin{array}{l}\text { Devel. } \\
\text { class }\end{array}$ & $\begin{array}{r}\text { No. of } \\
\text { patterns }\end{array}$ \\
\hline Southern & main area & 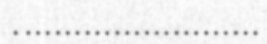 & 25 & 80 & 33 & 43 \\
\hline Western & , & 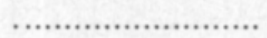 & 25 & 48 & 33 & 25 \\
\hline Middle & , & (2) & 84 & 197 & 109 & 161 \\
\hline
\end{tabular}

The average percentages of forest types and stand development classes are presented in Tables 17 and 18. A generalization of these figures to cover 
Table 17. The distribution of forest area, on boundary lines of cleared land, into site classes, in three main study areas (Observations of M. Keltikangas).

\begin{tabular}{|c|c|c|c|}
\hline & SF & W & MF \\
\hline 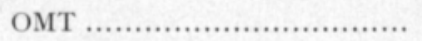 & - & - & - \\
\hline 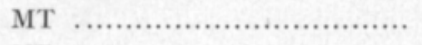 & 44 & 7 & 18 \\
\hline 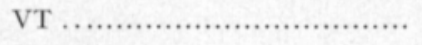 & - & - & 8 \\
\hline Spruce swamp ................... & 39 & 34 & 33 \\
\hline Pine swamp $\quad . . \ldots \ldots \ldots \ldots \ldots \ldots \ldots . \ldots . \ldots . \ldots$ & 17 & 31 & 13 \\
\hline Unproductive ..................... & - & 8 & 18 \\
\hline Waste land .......................... & - & 20 & 10 \\
\hline & 100 & 100 & 100 \\
\hline
\end{tabular}

Table 18. The distribution of forest area, on boundary lines of cleared land, to stand development classes, in three main areas. Ssm figures refer to entire forest area, per cent. ${ }^{1}$ )

\begin{tabular}{|c|c|c|c|c|}
\hline & SF & W & MF & Ssm \\
\hline Open areas, seed tree stands .............. & - & - & - & 14 \\
\hline Seedling or sapling stands $\ldots \ldots \ldots \ldots \ldots . . .$. & 20 & 68 & 22 & 4 \\
\hline Stands in thinning stage $. . . \ldots \ldots \ldots \ldots . . . . . .$. & 18 & 27 & 44 & 4 \\
\hline 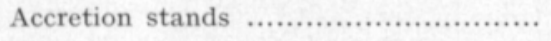 & 20 & - & 18 & 9 \\
\hline Mature stands to be regenerated ........ & 25 & 4 & 14 & 34 \\
\hline Shelter wood stands ......................... & - & 1 & - & 15 \\
\hline \multirow{2}{*}{ 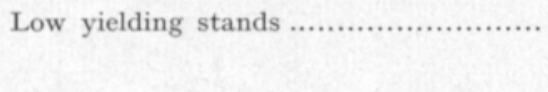 } & - & - & 2 & 20 \\
\hline & 100 & 100 & 100 & 100 \\
\hline
\end{tabular}

all cleared land is possible only with large margin error. In fact it is better to take these figures to reflect conditions only in parts of the subareas - probably those located in the more remote regions.

Among the forest site types, those on swampy soil seem to have the largest relative areas. Thus in SF, more than half, and in W two-thirds, are spruce or pine peat type, while in the latter nearly 30 per cent is on practically woodless soil, in MF 46 per cent is on tree-growing and 28 per cent on woodless peats. - Of the types on mineral soil, the Myrtillus type seems more often than the other to be cleared for cultivation.

The figures in Table 18 indicate that not only the mature stands, but to a large extent also seedling and sapling stands, as well as stands in the thinning stage, have been represented in areas which have been taken into cultivation. Mature stands were most frequent in the SF area, especially on mineral soils. Stands in the thinning stage covered over 40 per cent of the cleared area in $\mathrm{MF}$; major parts of these were on peat soils. In the $\mathrm{W}$ area, nearly 60 per cent of the land clearings were established on drained peats with seedling stands. The comparatively low land clearing costs may explain the wide use of young forests on swampy soils for cultivation.

1) Observations of M. Keltikangas, on Ssm area the Forestry Board officers. 


\section{Projections relating to the volume and value of potential cuttings}

Average figures on timber stands and growth on farms do not, as such, make projections of cuttings possible. As the estimations should be done relating to individual stands of all kinds of site type and development or age classes, it is impossible to carry out the task in this form. Instead, we are able to make estimations of a more general character, assuming a certain hypothesis e.g. on fully or partially stocked, regulated, even-aged natural stands. Such estimations are, however, possible only if there are appropriate yield tables, not only of various site classes and climatic conditions, but also of different alternative treatments of growing stands.

The yield tables available are based on investigations made for the most part in the Forest Research Institute and published by several authors (IlvesSAlo 1920, 1937; CAJANdER (KALEla) 1933; Nyyssönen 1954, 1958; Vuokila 1956, 1967; KoIvisto 1959 and Kallio 1957). They cover natural stands on most site types on mineral soils in Southern Finland, and in some tables alternative thinning treatments are assumed. In North Finland the natural stands on the most productive types are represented. The swampy soil forest types are not represented in the yield tables, nor the types created by peat drainage. The investigations of Heikurainen (1959) and SEPpäL $\ddot{A}$ (1969) are to some extent helpful when estimating the yield of these types. Taking into account the low volume and quality yield of undrained swamp soil forests, these generally add very little to the net return of farm forests. As a complement to the data of the yield tables the published results of the third National Forest Inventory $(1952 / 53)$ are to some extent useful, not only for the site types where yield tables are lacking but also in clarifying the differences between the widealn conditions of test areas and of average stands, often of uneven age composition or only partially stocked. The timber stands and growth figures are presented by site types and regions (Ilvessalo 1957, pp. 46, 48, 78); as, however, all these figures are not available by age classes, direct comparisons with yjeld tables are not possible.

For the estimation of the yields of North Finland stands treated with thinning cuttings the yield tables of Petterson (1963, pp. 296-372) based on test areas in Northern Sweden - mostly between $64^{\circ}$ and $66^{\circ}$ and $100-200$ $\mathrm{m}$ above sea-level - are used as a point of comparison. These tables are of practical value in as much as they are brought to a stage where the yields are expressed in commercial timber products, and even priced, although the price level used is of no direct relevance to our study. Unfortunately the treatment programmes of these investigations do not fully correspond to modern views of optimal management; the density of the initial stands does also to some extent differ from those in North Finland.

The greatest difficulties in applying the yield tables to this study have appeared when estimations on the distribution of the yields into various logging products are made. The computing programme for scaling the trees in most advantageous commercial lengths is rather complicated. For this purpose Petterson (1963, pp. 32, 492-494) has developed a method (putdragnings- 
metod») which is applied in his studies. ${ }^{1}$ ) We have applied this method for an estimation of the yield of natural pine stands on the Empethrum-Vaccinium (EVT) site type in Upper North Finland and North -Eastern Finland. In the estimations for South Finland and Middle Finland we have accepted the figures presented by NyYsSÖNEN (1958, pp. 82-86) which are included in the cutting plans for 3 site types predominantly with pine stands and 2 types with spruce stands. According to this author the average treatment of the test stands of his study has been well adopted. ${ }^{2}$ )

There are marked differences in the prices of saw-logs of various sizes (cf. later p. 372), and also in the stumpage prices of pulp wood of different diameter measures. Kallio (1957, p. 93) and Nyyssönen (1958, p. 39) have used in their computations certain empirical value relations between trees of different cubic foot volumes (cf. our Appendix I). Petterson (1963, pp. 90, 92), as stated above, has computed the volumes of the logs in different diameter classes, and accordingly uses the price relations of corresponding saw-log categories. We have not been able to fit together these methods of computation, and thus the results of Southern and Middle Finland may be based on somewhat different price relations. We use, in accordance with NyYssönEn, equal stumpage prices for pulp wood of different sizes, although we are aware that the logging costs are much higher in the thinnest categories (in our calculations for work time and labour income due attention has been paid to this fact).

For the selection of the rotation period, we have adopted the method of equating the marginal rate of return and costs (DUERR and BOND 1952, DUERR 1960, pp 129-138; NyYSSÖNEN 1958, pp. 16-24). It has not, however, been applied in the estimations covering the NE main area, where a 130 years' rotation period is used; this falls within the limits recommended for State forests (cf. Linnamies 1959, pp. 85, 145).

Owing to climatic differences, it can be expected that the yields of the $\mathrm{W}$ and MF areas would be lower than in the SF study areas. On this point some estimations presented by HEIKURAINEN (1959, p. 107) may offer a useful basis for corrections. Most of the test stands used for preparation of yield tables for the southern half of the country are located between the $60^{\circ} 30^{\prime}$ and $62^{\circ} 30^{\prime}$ latitudes, those of Upper North Finland around $67^{\circ}$, while the average location of the study areas and the relative volumes of growth ${ }^{3}$ ) according to the map of the said author are:

\begin{tabular}{|c|c|c|}
\hline 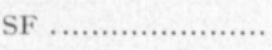 & $60^{\circ} 30^{\prime}-61^{\circ} 30^{\prime}$ & 103 \\
\hline 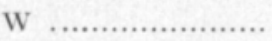 & $61^{\circ} 30^{\prime}-62^{\circ}$ & 95 \\
\hline MF ........................ & $62^{\circ} 30^{\prime}-63^{\circ} 30^{\prime}$ & $80-90$ \\
\hline Suomussalmi ........... & $64^{\circ} 30^{\prime}$ & 60 \\
\hline Kuusamo ............... & $66^{\circ}$ & 45 \\
\hline Salla $\ldots \ldots \ldots \ldots \ldots \ldots \ldots$ & $67^{\circ}$ & 35 \\
\hline
\end{tabular}

1) This procedure applies to stem portions where only the length and diameter govern the scaling of logs (Petrerson 1963, p. 493).

$\left.{ }^{2}\right)$ In a recent study of VuokiLA (1967) more detailed yield tables for pine stands are presented; the effects of thinnings of various strengths are there better described.

3) Southern part of the country an average of 100. 
Table 19. Estimates on the average sustained yield, the value of potential cuttings, and income from logging and hauling of the study farms, assuming average yields of different site types ${ }^{1}$ )

\begin{tabular}{|c|c|c|c|c|c|c|c|c|c|c|}
\hline & $\begin{array}{l}\text { Annual } \\
\text { growth } \\
\text { per ha } \\
\text { cu. m (s) }\end{array}$ & $\begin{array}{l}\text { Saw } \\
\text { logs } \\
\text { cu. ft }\end{array}$ & $\begin{array}{c}\text { Piled } \\
\text { indust. } \\
\text { wood } \\
\text { cu. m (p) }\end{array}$ & $\begin{array}{l}\begin{array}{c}\text { Fuel } \\
\text { wood }\end{array} \\
\text { cu. } m(p)\end{array}$ & $\begin{array}{c}\text { Stumpage } \\
\text { value } \\
\text { (gross) } \\
\text { mk }\end{array}$ & $\begin{array}{c}\text { Annual } \\
\text { cost } \\
\text { (taxes) } \\
\text { mk }\end{array}$ & $\begin{array}{c}\text { Stumpage } \\
\text { value } \\
\text { (net) } \\
\text { mk }\end{array}$ & $\begin{array}{r}\text { Loggi } \\
\text { hau } \\
\text { m.hrs }\end{array}$ & $\begin{array}{l}\text { and } \\
\text { gk }\end{array}$ & $\begin{array}{c}\text { Average } \\
\text { timber } \\
\text { stand } \\
\text { mk }\end{array}$ \\
\hline SF & 3.92 & 40.3 & 2.38 & 0.98 & 75.70 & 5.29 & 70.41 & 21.4 & 38.08 & 1238 \\
\hline W & 2.55 & 23.9 & 1.45 & 0.82 & 43.03 & 3.70 & 39.33 & 15.0 & 24.75 & 759 \\
\hline MF & 2.75 & 26.4 & 1.56 & 0.81 & 47.49 & 3.53 & 43.96 & 15.6 & 26.26 & 821 \\
\hline NE & . & 12.5 & 0.72 & 0.29 & $\begin{array}{c}12.47 \\
(13.88)\end{array}$ & 0.69 & $\begin{array}{c}11.78 \\
(13.19)\end{array}$ & 6.5 & 11.61 & 591 \\
\hline Ssm & . & 20.2 & 0.92 & 0.37 & $\begin{array}{c}21.42 \\
(23.60)\end{array}$ & 1.00 & $\begin{array}{c}20.42 \\
(22.60)\end{array}$ & 8.7 & 16.00 & 862 \\
\hline $\mathrm{Ku}$ & . & 10.5 & 0.78 & 0.33 & $\begin{array}{c}10.63 \\
(11.99)\end{array}$ & 0.60 & $\begin{array}{c}10.03 \\
(11.39)\end{array}$ & 6.8 & 11.76 & 524 \\
\hline Sa & . & 10.7 & 0.59 & 0.23 & $\begin{array}{c}10.07 \\
(11.19)\end{array}$ & 0.63 & $\begin{array}{c}9.44 \\
(10.56)\end{array}$ & 5.3 & 9.54 & 407 \\
\hline
\end{tabular}

To achieve an approximate comparability, the yields and values obtained by southern half calculations are multiplied by 0.93 for the $W$ area and by 0.85 for the MF area. To correct the values for the Kuusamo subarea the Upper North Finland figures are multiplied by 1.30, while the NE (Kainuu) yield tables are used as such for the Suomussalmi subarea.

The figures computed for different site types by regions are presented in Appendix VI. These include the average growth and estimated yearly quantities of saw-logs, piled industrial wood and fuel wood per hectare and year, the gross value of stumpage and its net value, i.e. when reduced by annual area bound costs. Further, the estimated number of working hours and labour costs in logging and hauling, and finally the average stumpage values of the timber stands during the rotation period are presented. In Table 19, the estimations are made for the average productive forest land of the study farms, using the percentages of site types mentioned in Table 19, and applying corrections, based on the simple assumption that the actual averages relate to the values computed for test areas in the same way as the annual growth per ha in the National Forest Inventory relates to the respective growth in the test areas. ${ }^{2}$ )

As previously stated, the figures presented are cautious approximations of the potential sustained yield and its value in the average conditions of the study farms.

The corresponding figures of the best forest site types in the respective regions may be interesting, as the most productive land often is taken for agricultural use. In the following figures no deductions are made except those motivated by zoning (p. 333).

1) For the North Eastem region, alternative prices are assumed for fine pulp wood., figures in parentheses).

2) This correction is not applied in the NE area, as the timber stands there are to a large extent mature; and the average growth does not correspond to the normal sustained yield within an appropriate rotation. An unwarranted 30 per cent reduction used sometimes elsewhere is here applied. 


\begin{tabular}{|c|c|c|c|c|c|c|c|c|c|}
\hline Area & $\begin{array}{l}\text { Site } \\
\text { type }\end{array}$ & $\begin{array}{c}\text { Rotation } \\
\text { years }\end{array}$ & $\begin{array}{l}\text { Aver. } \\
\text { growth } \\
\text { cu. m (s) }\end{array}$ & $\begin{array}{l}\text { Saw } \\
\text { logs } \\
\text { cu. ft. }\end{array}$ & $\begin{array}{c}\text { Piled } \\
\text { industr. } \\
\text { wood } \\
\text { cu. } m(p)\end{array}$ & $\begin{array}{c}\begin{array}{c}\text { Fuel } \\
\text { wood }\end{array} \\
\text { cu. } m(p)\end{array}$ & $\begin{array}{l}\text { Stum- I } \\
\text { page } \\
\text { value } \\
\text { mk }\end{array}$ & $\begin{array}{c}\text { Logging \& } \\
\text { hauling } \\
\text { m. hrs }\end{array}$ & $\mathrm{mk}$ \\
\hline SF . & OMT & 80 & 6.59 & 72.7 & 4.09 & 0.95 & 138.80 & 38.9 & 73.34 \\
\hline W ……......... & MT & 90 & 4.73 & 52.4 & 3.00 & 0.86 & 98.30 & 30.0 & 59.81 \\
\hline \multirow[t]{2}{*}{ MF ….......... } & MT & 90 & 4.47 & 49.5 & 2.83 & 0.81 & 92.80 & 26.8 & 53.87 \\
\hline & VT & 90 & 4.08 & 39.7 & 2.27 & 1.32 & 69.10 & 27.5 & 50.47 \\
\hline NE ...... & & - & - & - & - & - & - & - & - \\
\hline Ssm ................. & EVT & 100 & 3.80 & 39.0 & 1.92 & 0.47 & 35.85 & 18.1 & 37.27 \\
\hline Sa .... & EVT & 100 & 3.30 & 38.7 & 1.37 & 0.18 & 25.01 & 12.8 & 28.09 \\
\hline
\end{tabular}

As already stated, for one of the most productive forest site classes in the NE area, EVT, parallel estimations based on the same material are made using the scaling method of Petterson (cf. above p. 332). The figures obtained are here presented for comparison (B), as well as figures (C) compiled from one of the type cases representing Northern Sweden pine forests, published by the same author. ${ }^{1}$ ) Two alternative rotation periods are further taken as comparisons:

\begin{tabular}{|c|c|c|c|c|c|c|c|c|}
\hline \multirow[t]{2}{*}{ Region } & & \multirow{2}{*}{$\begin{array}{l}\text { Rota- } \\
\text { tion } \\
\text { yrs. }\end{array}$} & \multirow{2}{*}{$\begin{array}{l}\text { Growth } \\
\text { cu. m (s) }\end{array}$} & \multirow{2}{*}{$\begin{array}{l}\text { Logs } \\
\text { cu. } \mathrm{ft} .\end{array}$} & \multirow{2}{*}{$\begin{array}{l}\text { Piled } \\
\text { industr. } \\
\text { wood } \\
\text { cu. } m(p)\end{array}$} & \multirow{2}{*}{$\begin{array}{c}\begin{array}{c}\text { Fuel } \\
\text { wood }\end{array} \\
\text { cu. } \mathrm{m}(\mathrm{p})\end{array}$} & \multicolumn{2}{|c|}{$\begin{array}{l}\text { Stumpage } \\
\text { value }^{2} \text { ) }\end{array}$} \\
\hline & & & & & & & Alt. 1 & Alt. \\
\hline \multirow[t]{2}{*}{ NE } & ......... & 100 & 3.8 & 39.0 & 1.92 & 0.47 & $35: 85$ & $41: 80$ \\
\hline & В ……......... & 100 & , & 43.0 & 1.54 & - & $39: 31$ & $43: 99$ \\
\hline \multirow[t]{2}{*}{ Ssm } & A $\ldots \ldots \ldots$ & 130 & 3.5 & 49.0 & 1.33 & 0.30 & $47: 73$ & $51: 89$ \\
\hline & В …............... & 130 & - & 44.1 & 1.46 & - & 43:81 & $48: 27$ \\
\hline \multicolumn{9}{|c|}{ Upper } \\
\hline \multirow[t]{2}{*}{ NF } & A & 100 & 3.3 & 29.3 & 1.37 & 0.18 & $25: 01$ & $28:$ \\
\hline & В …............. & 100 & " & 22.6 & 1.89 & 0.10 & 20:35 & $24: 16$ \\
\hline \multirow[t]{2}{*}{ Sa } & A …............. & 140 & - & 31.0 & 1.63 & 0.18 & $28: 84$ & 31:95 \\
\hline & В ….............. & 140 & - & 24.8 & 1.59 & - & $22: 39$ & $25: 6$ \\
\hline \multicolumn{9}{|c|}{$\begin{array}{l}\text { Northern } \\
\text { Sweden }{ }^{3} \text { ) }\end{array}$} \\
\hline & $\mathrm{C}$ & 98 & 2.8 & 15.6 & 2.38 & - & 10:72 & $19: 8$ \\
\hline & C $\ldots \ldots \ldots$ & 138 & 3.0 & 26.6 & 1.95 & - & $20: 23$ & 26: \\
\hline
\end{tabular}

The differences between the values in rows $\mathrm{A}$ and $\mathrm{B}$, arising from different methods of estimation of yield and the price of saw logs, indicate that the method used in our standard calculations (A) leads in most cases to higher stumpage values than the Swedish scaling method (B). The physical output and stumpage values estimated from Swedish test areas (C) is much lower than those estimated in the North Finland studies, which are based on natural stands.

\footnotetext{
1) One of the most remunerative alternatives (P7) is chosen, on a site class with a dominant height of $20 \mathrm{~m}$ at a stand age of 100 years and with standard low thinning resp. proportionate thinning percentages 5 and 1 every 5 year period. The number of trees was 8920 per hectare before thinning at the age of 38 years, 1745 in the 98 years stand.

2) See footnote to Table 19 .

3) Prices of the NE region are applied. Alternative 2. presupposes higher price for pine pulf wood (5:60 per cu. m (p)).
} 


\section{Comparisons with other relevant data}

As stated above, the figures relating to study farms presented here describe primarily potential sustained yields and stumpage values based on these assuming the price level of 1959-63. There is no direct comparability between these and the actual annual cuttings and their value. Nevertheless, a few comparisons with some available data are made here in order to maintain contact with the practical results.

On the basis of the data of the Profitability Investigations the following figures may be given on the taxable net returns of forestry per hectare in the regions covering the corresponding main study areas (the averages have been previously published by PiHKala 1965, p. 38).

$\begin{array}{cccc} & \text { SF } & \text { W and MF } & \text { NE } \\ 1958 / 59-1962 / 63 \ldots \ldots \ldots . . . . . . . .3:- & 39:- & 26:- & 7:-\end{array}$

These figures may be compared with the respective averages presented by Runeberg $(1968$, p. 19) on the business surplus of forestry on 448 bookkeeping farms (total number of farms in the P. I. is about 1200) in the four year period 1960-64. Runeberg further presented figures from collectively managed forests (altogether $35215 \mathrm{ha}$ ). The business surplus is the difference between the gross return and current expenses, not taking into account any standing timber balances (cf. PIHKala 1965, p. 31).

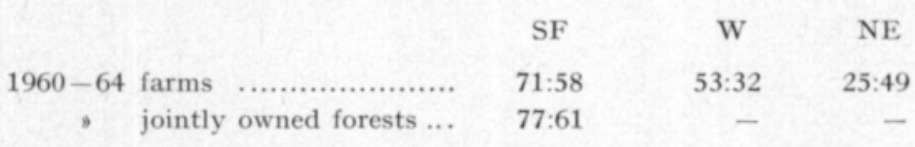

The same author has also computed the average incomes that have been applied in forest taxation according to the areabound system in use for the time being in Finland (cf. KIvivuori 1958). The averages are, respectively, 43: 86 (43:53 in jointly owned forests), 29: 67 and 8: 53. The large differences between the averages from the same regions may be explained partly by the exploratory fellings especially in the northern half of the country.

Some averages relating to colonization farms, computed from a small sample presented by the Board of Colonization comprise not only the stumpage values per hectare, but also the timber stand and allowable cut figures, whereby also the average prices per cu.m (s) are noted (Byman 1967, pp. 128-129). The study relating to the Middle and North Eastern Finland pioneer farms, referred to above (p. 326) is also interesting as a comparison. Although there are only very few cases especially in the region corresponding to our NE subareas, we feel justified in examining their five-years averages which are results of detailed observations.

In an attempt to find geographically comparable farm groups, we have computed the following averages from the figures presented in the above investigations: 
(a) Full-time colonization farms

(BYMAN) $^{1}$ ) 1965

\begin{tabular}{|c|c|c|c|c|}
\hline & SF & W & MF & $\begin{array}{c}\mathrm{NE} \\
\text { Kainuu }\end{array}$ \\
\hline Number of farms .......... & 28 & 8 & 53 & 19 \\
\hline Timber stand, cu. m (s) per ha .......... & 111 & 78 & 90 & 82 \\
\hline Allowable cut, cu. m (s)/year ............. & 2.39 & 1.65 & 2.28 & 2.45 \\
\hline Stumpage value, $\mathrm{mk} / \mathrm{ha} /$ year $\ldots \ldots \ldots \ldots . . .$. & $81: 20$ & $30: 48$ & $46: 80$ & $30: 94$ \\
\hline $\mathrm{mk} / \mathrm{cu} . \mathrm{m}(\mathrm{s}) \quad \ldots \ldots \ldots . .$. & $24: 15$ & 21:60 & 20:94 & $14: 70$ \\
\hline
\end{tabular}

(b) Pioneer farms, 1955-591)

\begin{tabular}{|c|c|c|c|}
\hline & MF & Ssm & Ku \\
\hline 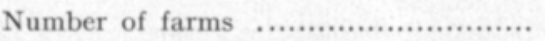 & 13 & (2) & (2) \\
\hline Timber stand, cu. m (s)/ha ............... & 75 & 92 & 78 \\
\hline 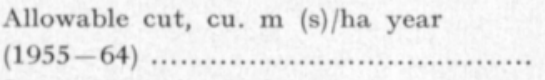 & 2.16 & 3.08 & 2.04 \\
\hline $\begin{aligned} \text { Stumpage value, } & \mathrm{mk} / \mathrm{ha} / \text { year } \\
& \mathrm{mk} / \mathrm{cu} . \mathrm{m}(\mathrm{s})\end{aligned}$ & $\begin{array}{r}18: 58 \\
9: 05\end{array}$ & $\begin{array}{r}15: 96 \\
6: 95\end{array}$ & $\begin{array}{r}15: 49 \\
7: 64\end{array}$ \\
\hline Farm income from logging \& hauling & $12: 66$ & $17: 97$ & $19: 60$ \\
\hline Wages bill ..................................... & $1: 99$ & $0: 40$ & $2: 68$ \\
\hline 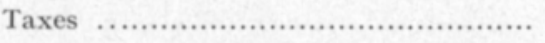 & $1: 71$ & $0: 57$ & $0: 29$ \\
\hline $\begin{array}{l}\text { Obligatory payment to Forestry Board } \\
\& \text { selling costs }\end{array}$ & $0: 55$ & $0: 28$ & 0:09 \\
\hline
\end{tabular}

Taking into account the large fluctuations in the timber prices during the period 1951-1965 (the prices of 1965 were more than double compared to the period 1955-58, see Appendix I), the values computed for Table 19 are of the same order of magnitude as these.

The book-keeping results of State Forests, published in the Statistics of the Forestry Board, may also be used for comparison. These include the actual yearly cuttings, allowable cut according to the management plan, business surplus and paid wages, all computed per hectare of productive forest land. The State Forests consist of rather large administrative areas, and are managed by officials of the Forestry Board. The results from the State Forests closest to our study areas are listed in the following tabulation:

\begin{tabular}{|c|c|c|c|c|c|}
\hline & SF & W & MF & Ssm & Ku \\
\hline $\begin{array}{l}\text { Actual cuttings, } 1959-63 \text {, cu.m } \\
\text { (s) /ha } \ldots \ldots \ldots \ldots \ldots \ldots \ldots \ldots \ldots \ldots \ldots \ldots \ldots \ldots \ldots \ldots \ldots \ldots \ldots\end{array}$ & 6.64 & 3.79 & 2.90 & 1.60 & 1.27 \\
\hline Planned cuttings, cu. $\mathrm{m}$ (s) ....... & 2.80 & 2.70 & 2.25 & 2.54 & 1.50 \\
\hline Business surplus, mk/ha ........... & $119: 31$ & $42: 10$ & 18:09 & $8: 03$ & $9: 10$ \\
\hline $\begin{array}{l}\text { Reduced surplus, assuming sustai- } \\
\left.\text { ned yield }{ }^{2}\right)\end{array}$ & $50: 30$ & 29:99 & $14: 23$ & $15: 88$ & $10: 75$ \\
\hline 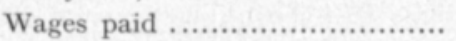 & $57: 64$ & $30: 75$ & $37: 33$ & $14: 54$ & $14: 67$ \\
\hline Silvicultural costs $\mathrm{cu} . \mathrm{m}$ (s) ....... & $3: 53$ & $3: 56$ & 5:09 & 1:39 & $0: 83$ \\
\hline Price of timber mk/cu. $\left.\mathrm{m}(\mathrm{s})^{3}\right) \ldots$. & $18: 49$ & $18: 49$ & $13: 64$ & $11: 90$ & $11: 90$ \\
\hline
\end{tabular}

1) Averages per ha of productive forest.

${ }^{2}$ ) The relation of planned and actual cuttings has determined the reduction used here.

3) Regional average. 
If we take these to be reliable figures, the stumpage prices paid for timber sold from State forests have been somewhat lower than those paid to farmers. The sales are comparatively low e.g. in the MF and NE areas. This may be partly due to deliberate restictrions, imposed by authorities favouring colonization. In the SF and $\mathrm{W}$ areas, the sales, on the other hand, seem to have exceeded the allowable cut.

\section{The farm income from forestry}

To prove the significance of forestry income to the owners of study farms, an estimation of the total income from forestry will be presented here below. The stumpage values as well as the income from logging and hauling are computed, using the average productive forest area as multiplicator. The family incomes from agriculture, printed on p. 327, are taken for comparison. The figures per hectare are also repeated.

\begin{tabular}{|c|c|c|c|c|c|c|c|}
\hline Mk, per farm & SF & w & MF & NE & Ssm & Ku & Sa \\
\hline Income from forestry & 1641 & 2701 & 3190 & 2515 & 3220 & 1739 & 2500 \\
\hline Thereof stumpage value $\ldots$ & 1092 & 1715 & 2054 & 1302 & 1843 & 932 & 1194 \\
\hline - logging \& hauling & 549 & 986 & 1136 & 1213 & 1377 & 766 & 1206 \\
\hline Income from agriculture ........ & 4582 & 2237 & 2339 & 2830 & 3995 & 1891 & 3078 \\
\hline Farm income, total ................. & 6223 & 4938 & 5529 & 5345 & 7215 & 3630 & 5578 \\
\hline \multicolumn{8}{|l|}{ Per hectare } \\
\hline forestry & 114 & 68 & 74 & 24 & 37 & 22 & 20 \\
\hline agriculture ......... & 512 & 365 & 298 & 509 & 507 & 616 & 448 \\
\hline
\end{tabular}

The figures presented here indicate the significance of forestry on pioneer farms as a source of a complementary income. On the other hand, a much lower income per hectare is obtained from forestry compared with agriculture. Low compensation per working hour is ,however, a characteristic of agricultural production. These findings are by no means new in this country. The data now established may, however, prove helpful in our subsequent analysis.

\section{Land rent of forestry compared with that obtained in agriculture}

Land rent of forestry is computed here by deducting the interest on the average market value of a timber stand in a given rotation period from the gross stumpage value (Table 19). A 3 per cent rate of interest is used here as well as in other calculations (cf. below, p. 348). No deductions are made for yearly silvicultural costs; in the natural stands these consist generally of silvicultural charges which amount to $\mathbf{3} \mathbf{- 5} \mathbf{~ m k}$ per hectare. The land rent of forestryis compared with the land rent observed in agricultural production (Table $16 \mathrm{p}$. 76. Two alternatives, assuming different price levels of labout hours (2:32 and). 1:39-1:42 per hour, cf. p. 74) are presented. The interest on capital invested in land clearing is not in this case taken into account. 
Land rent by study areas, $\mathrm{mk} / \mathrm{ha}$

\begin{tabular}{|c|c|c|c|c|c|c|c|}
\hline & SF & W & MF & $\mathrm{NE}$ & Ssm & $\mathrm{Ku}$ & $\mathrm{Sa}$ \\
\hline Forestry ................... & 39 & 20 & 23 & -5 & -4 & -5 & -2 \\
\hline \multicolumn{8}{|l|}{ Agriculture } \\
\hline alt. 1 .................. & -236 & -451 & -424 & -343 & -164 & -505 & -295 \\
\hline alt. 2 ................ & 46 & -140 & -148 & -15 & 95 & -79 & -50 \\
\hline
\end{tabular}

The cost of land clearing, assuming mechanized methods of clearing, has been approximately $800-1300 \mathrm{mk}$ per hectare, in the $1959-63$ monetary value. ${ }^{1}$ ) The subsidies for land clearing have been in the size class of most study farms $(5-10$ ha) 40 per cent of the costs, in the NE main area 50 per cent. If a 3 per cent rate of interest is applied to the gross and net investments, the land rent in agriculture should have dropped by $24-39 \mathrm{mk}$ per hectare in the first case, and $14-23 \mathrm{mk}$ or $12-20 \mathrm{mk}$ (NE main area) in the second. Even if such a low rate of interest and low labour remuneration is assumed, the actual land rent to an owner who has invested in land clearing is negative or only slightly positive.

1) For a detailed calculation of the costs, see the mimeographed report (Finnish Study Group, pp. $100-109$ ). 


\section{Marginal calculations on the extension of agricultural production by land clearing}

The marginal calculation is here characterized by a derivative of simple production function where the inputs in the farm in the form of land, capital or labour are, taken as independent variables and certain indicators of business results as dependent ones. (cf. TreloAR \& Morison 1962, p. 8). The data should be from cumputations made for farms of different sizes, assuming that those technical coefficients which are not dependent on economics of scale are unaffected by the increase of area. Only linear or Cobb-Douglas forms of production functions are here applied.

The usual method in marginal calculations has been based on comparisons of the net results of two successive size classes of book-keeping statistics (cf. above pp. $30-31,34$ ). The available averages from the Profitability Investigation, however, are hardly useful for our purposes as such. There is no evidence that the smaller and larger farms represent the same site quality type and intensity level in plant production; in fact there are differences in the use of fertilizers and in the level of crop yields per hectare. The relative volume of animal production is regularly smaller in the larger size classes as compared to the smaller ones. On the other hand, we do not believe that the averages of labour use are fully comparable in reliability and take into account the different combinations of resources. Thus, although we use in our calculations some averages from the Profitability Investigation, we follow a somewhat different procedure, especially as it would not be justifiable to use merely figures which have no direct connection with our own empirical material.

In the following, some calculations are made on the effect of an increase by one hectare of the cultivated area on economic results, farm income, social output, net return and land rent. The limitations of this kind of estimation will be discussed later.

In the estimations presented here it has been assumed that the gross output per hectare does not change in respect to value or composition, except for the fact that the more effective use of horses saves to some extent both marketable and non-marketable feed for sale or for use in livestock production. We have reason to assume that the averages of the Profitability Investigation (see above p. 321) on the costs of tractive power in respect to the relation of per hectare cost are otherwise at least approximately comparable; e.g. there is much 
similarity between book-keeping farms and study farms with respect to the number of horses and tractors (cf. Table 7 p. 317).

In Appendix III, the computation fo fodder saving per an increase of one hectare in cultivated area is presented, applying the regional averages of the P.I. and the averages of the study farms. The saving in money is estimated pricing the concentrates at -:33 per fodder unit and non-marketable fodder at $-: 20$, the value which approximately corresponds to the net value of nonmarketable feed in livestock feeding (TSMK 1964, p. 61). This saving varies considerably between the study areas, being largest in areas where the average farm size is smallest, especially if the number of horses per hectare is relatively high.

There will also be some saving in the costs of horse and cart capital. This is estimated from the averages of the Profitability Investigation.

The comparisons of per hectare costs of tractors and field machinery (see above p. 68) shows that there is in all regions some rise in these costs when moving from size classa I to II.

The combined cost of horses, tractors and field machinery are expected to change when moving from size class I to II, in $\mathrm{mk}$ per ha:

\begin{tabular}{|c|c|c|c|}
\hline & SF & $\mathrm{W}+\mathrm{MF}$ & NE \\
\hline Feed cost of horses & $-22: 68$ & $-23: 69$ & $-18: 94$ \\
\hline Various money expenses ........... & $-1: 03$ & $-1: 07$ & $-0: 87$ \\
\hline Interest \& depreciation $\ldots . . . . . . .$. & $-5: 42$ & -4.94 & $-4: 51$ \\
\hline 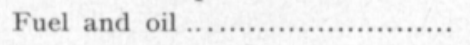 & $+0: 82$ & $+6: 84$ & $+4: 41$ \\
\hline Machine hire …......................... & $-1: 98$ & $-4: 34$ & $-3: 39$ \\
\hline Depr. \& reparations .................. & $+5: 46$ & $+17: 36$ & $+3: 86$ \\
\hline Interest of machines .................. & $+2: 50$ & $+5: 07$ & $+0: 84$ \\
\hline & $-22: 33$ & $-4: 77$ & $-18: 60$ \\
\hline
\end{tabular}

Similar calculations on the effect of the extension of the field area on the per hectare costs of buildings are possible in two alternative ways: using the averages of the P. I. or the values presented in the upper part of Table 12, based on the cost figures of the Land Settlement Investigation Committee (cf. p. 322). In the latter case, the results differ much more between the study areas, as the comparison is between a $\mathbf{1 5}$ hectare farm and actual farm sizes, varying greatly region by region.

The yearly costs of buildings are affected quite differently in cases where an increase by one hectare in the cultivated area does not lead to extension of buildings, compared with those where larger buildings become necessary. This is illustrated by the following figures from Appendix IV, showing the effect of an one hectare increase of cultivated area on yearly costs of buildings. (The depreciation, repairs, insurance and 3 per cent interest are here included.)

1) The change in the costs of the care of horses was not taken into account. If the price of labour is 1:40, this would mean a further reduction of $6:--15:-$ per hectare. 
Saving in yearly costs, assuming an one hectare increase in cases with no need for enlarged building space:

\begin{tabular}{|c|c|c|c|c|c|c|c|}
\hline & SF & w & MF & $\mathrm{NE}$ & Ssm & $\mathrm{Ku}$ & Sa \\
\hline rofitability Investigatio & 10.75 & \multicolumn{2}{|c|}{10.56} & 11.78 & - & - & - \\
\hline ctul basis & 11.21 & 22.53 & 14.37 & 27.38 & 14.27 & 79.89 & \\
\hline
\end{tabular}

Average saving in yearly costs, $\mathrm{mk} / \mathrm{ha}$, if extension of cultivated area is combined with appropriate larger type of economy building:

Profitability Investigation 23.96

Actual basis

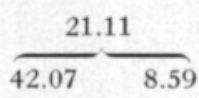

34.85

60.92

$8.10 \quad 146.26$

26.71

The large differences between the estimated values in both these cases indicate the difficulty of making calculations of general validity. The largest amount of saving by an extension of cultivation is naturally obtainable when the capacity of buildings has at the time of observation been only partially utilized (e.g. Kuusamo subarea). The barn-house is here a discontinuous factor, and the stepwise increase of other inputs will give savings only to a certain point, where another building is needed or a larger type of building should have been chosen. Thus, in Appendix IV (3) it has been shown that in the Kuusamo subarea, the extension of cultivation to over six hectares (assuming an unchanged structure of production) at first increases the yearly cost per hectare (in consequense of moving to the type 1 building), and only when the 11 hectare size is passed, are further savings in costs possible.

If we assume an unchanged ratio between the number of cows and the cultivated area, and take into account the fact that the maximum number of cows which can be kept over winter in the type 2 building is seven, we find that the farms of the NE main area cannot be enlarged to 15 hectares except when the larger building type $\mathbf{1}$ is taken into use. We presume, as alternative 1 , that land clearing is advisable only to the limit of type 2 building, and thus find the upper limit of cultivated area in the NE an average of 11.76 ha, and in subareas Ssm, $\mathrm{Ku}$ and $\mathrm{Sa}$ in respectively $12.45,7.85$ and 12.40 ha. As alternative 2 , we assume the type 1 building taken into use after the extension (naturally according to the plan made when the farm was established). The extension of cultivation by land clearing then saves the yearly costs of building capital per hectare by study areas.

\begin{tabular}{|c|c|c|c|c|c|c|c|}
\hline & SF & W & MF & NE & Ssm & Ku & $\mathrm{Sa}$ \\
\hline $\begin{array}{l}\text { Alt. } 1 \\
\text { rep \& depr. ................ }\end{array}$ & 23.36 & 49.66 & 31.49 & 49.17 & 24.15 & 102.85 & 33.65 \\
\hline interest ...................... & 8.76 & 18.76 & 11.81 & 18.45 & 9.06 & 38.56 & 12.62 \\
\hline $\begin{array}{l}\text { Alt. } 2 \\
\text { rep. \& depr. .............. } \\
\text { interest }\end{array}$ & -4.31 & $\begin{array}{r}25.92 \\
8.80\end{array}$ & $\begin{array}{l}5.24 \\
1.67\end{array}$ & 37.21 & $\begin{array}{l}4.94 \\
1.58\end{array}$ & 126.07 & 16.30 \\
\hline
\end{tabular}


In the following calculations, the interest on building capital is treated as a separate item, as the claims of capital as well as labour may not in all cases be fully satisfied. We have two alternatives, on where no enlarged building space is needed and an other, where full utilization of type 1 building will be attained by the extension of the cultivated area.

We can expect that the requirement of labour hours per hectare decreases with the extension of the cultivated area. To use the differences between the averages of the size classes I and II of the Profitability Investigation as an indication of the saving of labour when moving to a larger farm size is, however, scarcely justifiable, for reasons already referred to (pp. 323-324). In the conditions of the study farms, where hiring or reciprocal use of horses and machines is usual, there are no particular differences in the average efficiency of human labour used in field work, except in cases where lack of other employment may adversely affect efforts to achieve normal performance. ${ }^{1}$ ) We assume, therefore, only a small (10 per cent) difference in the labour use per hectare in the field work in size class II (which we regard as having 15 hectares of cultivated land) as compared with size class I (7.5 ha). $\left.{ }^{2}\right)$

This assumption may be valid only with regard to the differences in effective working time. ${ }^{3}$ ) The waste time in the field work on small farms is so indeterminable that too much attention to statistical averages cannot be paid. The economics of scale plays a role which is easier to determine in the care of livestock than in field work which has a strongly seasonal character. The use of labour for milk production is therefore differentiated according to the average number of cows in the herd, following the scale presented in Appendix V. The actual use of labour per hectare after extension, as well as the saving of labour in working hours and its value per hectare, applying the same price alternatives as in earlier computations, is tabulated below.

\begin{tabular}{|c|c|c|c|c|c|c|c|}
\hline \multirow[b]{2}{*}{ Cultiv. area } & \multirow[t]{2}{*}{ SF } & \multirow[t]{2}{*}{ w } & \multirow[t]{2}{*}{ MF } & \multirow[t]{2}{*}{ NE } & \multicolumn{2}{|c|}{ Subareas } & \multirow[b]{2}{*}{ Sa } \\
\hline & & & & & Ssm & Ku & \\
\hline after ext., ha ............ & 15 & 15 & 15 & 11.76 & 12.45 & 7.85 & 12.40 \\
\hline Man hrs/ha ................ & 272 & 265 & 250 & 282 & 240 & 327 & 257 \\
\hline $\begin{array}{c}\text { Saving in } \mathrm{man} \text { hrs. ... } \\
\text { in } \mathrm{mk} / \mathrm{ha}\end{array}$ & 50 & 82 & 60 & 82 & 50 & 146 & 62 \\
\hline Alt. 1 ............. & 11600 & 190.24 & 139.20 & 190.24 & 116.00 & 338.72 & 143.84 \\
\hline Alt. $2 \ldots \ldots \ldots \ldots$ & 71.00 & 114.80 & 84.00 & 113.98 & 69.50 & 202.94 & 86.18 \\
\hline
\end{tabular}

1) The observations of SANDQvist (1963, pp. 39, 42) on the differences of labour use per hectare or cattle unit between farms, the owners of wich are doing more than 10 per cent of their labour input in of-farm work, and hose who are doing less, are interesting in this connection. In the smallest size class, there is a labour input that is approximately 20 per cent higher on farms with a small non-farm income than, on farms with a larger non-farm income.

${ }^{2}$ ) This approximately the ratio used in Swedish data for planning (HJELM: Databok för driftsplanering, Lbhgsk:ns medd. Ser. B. 1. 1963)

3) In Sweden, according to SANDQvist (p. 39), the per hectare average labour use for plant production was cut down on the farms of Jordbruksekonomiska Undersökningen from 175 to 130 man hours when switching over from the average size of 5 ha to 10 ha, and respectively to 105 man hours when moving further to an average size of 15 ha. These reductions correspond to 26 and 19 per cent. 
It appears from the above table that the saving of labour is considerable in areas where the number of cows per farm is small, and where the savings of capital costs are greatest.

We can assume that the savings due to the economics of scale consist mainly of the itemş discussed in this chapter. The marginal calculations based on this assumption have given values which are presented in Table 20.

Figures of Table 20 indicate that the marginal returns, especially in cases where net results are concerned, are generally higher than the average returns, and that extension of cultivated area by land clearing in the limits here assumed, was generally more advantageous than land clearing activities connected with establishing new units with field areas that apparently were too small. The variance between the study areas can be explained by the fact that the present average size of farms more or less deviates from the optimum size (which, however, is not exactly determinable).

Table 20. Marginal returns obtained by extension of cultivated area, A per additional hectare, working hour or $100 \mathrm{mk}$ of capital (linear function). B as ratio of infinitely small increments of respective quantities (linear function in logarithmic scale).

A. Linear function $\mathrm{mk} / \mathrm{ha}\left(\mathrm{X}_{1}=\right.$ cultiv. area, $\mathrm{X}_{2}=$ labour hours.

$\mathrm{X}_{3}=$ investment)

SF W MF NE Ssm Ku Sa

$\mathrm{X}_{1}, \mathrm{Y}$

Gross margin ................... $635 \quad 490 \quad 385 \quad 669 \quad 630 \quad 684 \quad 597$

Social output

684

524

415

586

$669 \quad 938$

638

Taxable net return

\begin{tabular}{|c|c|c|c|c|c|}
\hline Alt. 1 ......................... 305 & 88 & 131 & 175 & 410 & 473 \\
\hline Alt. 2 . & 273 & 212 & 353 & 544 & 673 \\
\hline
\end{tabular}

Land rent

Alt. 1

364

114

172

214

$479 \quad 508$

349

Alt. 2

$534 \quad 295$

253

393

$613 \quad 708$

558

Remuneration to labour

(no land rent or interest on

fixed capital

507

413

585

706

921

652

$\mathrm{X}_{2}, \mathrm{Y}$

Remuneration to labour per additional working hour (no land rent or interest on fixed capital)

$\mathrm{X}_{3}, \mathbf{Y}$

Remuneration to additional capital per $100 \mathrm{mk}$

Alt. 1

Alt. 2 


\begin{tabular}{|c|c|c|c|c|c|c|c|}
\hline & SF & W & MF & NE & Ssm & Ku & Sa \\
\hline Gross margin ...... & 1.05 & 1.00 & 0.97 & 1.02 & 1.02 & 1.01 & 1.04 \\
\hline Social output $\ldots \ldots \ldots \ldots \ldots \ldots \ldots \ldots \ldots \ldots \ldots \ldots$ & 1.12 & 1.12 & 1.08 & 0.98 & 1.11 & 1.17 & 1.15 \\
\hline \multicolumn{8}{|l|}{ Taxable net return } \\
\hline Alt. 2 ............................ & 2.67 & 1) & 1) & 2.61 & 2.38 & 3.63 & 1) \\
\hline \multicolumn{8}{|l|}{ Land rent } \\
\hline Alt. 2 ........................... & 4.22 & 1) & 1) & 1) & 3.40 & 1) & 1) \\
\hline Labour income ...................... & 2.61 & 1.76 & 1.89 & 1.63 & 2.21 & 2.11 & 2.05 \\
\hline \multicolumn{8}{|l|}{ Remuneration to cap. } \\
\hline Alt. 2 ............................ & 1.46 & 1) & 1) & 2.03 & 1.28 & 3.90 & 1) \\
\hline
\end{tabular}

The extension of agricultural production by land clearing on a farm is normally connected with a corresponding drop in forest production. For the same reason as in agricultural production, the marginal loss in forest returns may deviate from the average. In this case, we shall not, however, attempt to estimate the marginal returns. Suffice it for us to ascertain that in the conditions of our study farms, where the forest area is generally managed by family labour only, and where the size of the enterprise is too small to allow advanced mechanization, the economics of scale plays a relatively small part in the costs of labour. Unlike in agricultural production, costs of fixed capital that would be affected by economics of scale hardly exist.

In our attempt at a marginal analysis there are a number of weak points. It is, for example, too dependent on the flexibility of other productive resources other than land. In fact, this approach is scarcely to be recommended when compared to another approach, which will be discussed below in the following chapter VII.

1) indeterminable because of negative values. 


\section{Land clearing in the different site and age classes of timber stands}

Land clearing activities are in general carried out on areas where favourable conditions for agricultural production are believed to exist. It is probable that the anticipated costs of land clearing may also play a part in the decisions. The subsidies paid, and their relation to the actual costs presumably also have some influence. What part the future loss of forest value growth is playing, may be less clear to the decision makers.

This estimation problem may in some cases be solved by long time averages, e.g. if a periodically cut uneven age stand is cleared. Normally there are cases where mature or unmature stands, or even stands in an early stage of development are taken into cultivation. There may be a young forest which has no felling value as yet, but where a calculable expectation value exists.

What is the income actually lost in the case of premature felling? The discounted value of a future harvest is something unreal, it becomes a realistic factor only by the sale of land or of future felling rights. The interest on this value may be regarded as a hypothetical measure of the potential income. SAARI (1937, p. 174) has used it as a measure of a yearly sustained yield value and only with the assumption of forest enterprise ${ }^{1}$ ). ENDRES (1911, p. 44) already introduced the concept, however, not utilizing it. HAGBerg (HJELM 1956, p. 63), as stated earlier (p. 301), has used it for representing land rent. However, it must be understood as a permanent yearly income, which as such is of no great interest to an entrepreneur who plans only for limited periods, seldom in excess of $20-40$ years. If the entrepreneur has to establish an alternative production line, he may be obliged to take a loan and pay not only interest but also amortization. Thus the yearly opportunity cost will preferably be estimated according to the annuity principle $\left.{ }^{1}\right)$. It must be admitted, however, that the relevance of computed annuities for our purpose is critically diminished where the period is lengthened e.g. to over $20-40$ years.

When the timber stand acquires market value, the interest of this value gradually covers the computed loss in the interest of the expectation

1) He uses expressions, according to which the confinement to the plan is stressed. The

formula used is $\frac{\mathrm{p}}{100} \cdot \frac{\mathrm{Hn}}{1 . \mathrm{Op}^{\mathrm{n}}}$. The plan, however, can presuppose even an expanding average productivity in the future. Later other Finnish research workers have further developed this line of thought (LiHtonen, KuUsela, Nyyssönen). 
value or in annuities. In fact, it may even exceed it, showing that even premature fellings can yield a gain, though only within a short-term plan. In continuing forest management, the potential gains in the oldest age class do not solely determine the average net return; every age class contributes to it, and the continuation of the rotation is necessary to balance with the gains of later years the losses of younger age classes.

Another alternative for the estimation of the potential income is the value growth with e.g. 10 or 20 years. Value growth is here understood as the increase of the marketable value of timber stand, added with the net value of thinning or accretion cuts. Value growth is in fact not much more real than the rise in expectation value; in the younger age classes it can be realized only if the wood lots have been the object of transactions. When comparing the value growth with the market value of a timber stand, discounting is not applied, and the yearly values are thus obtained simply by division with the number of years.

The rate of interest considerably affects calculations of this kind. The determination of the rate is, as is generally admitted, difficult in cases where investments paid by money loaned at a fixed rate are not involved. We have above presented an experimental assumption of a future market for felling rights, and accordingly - a pricing of expectation values on this market. Unfortunately these values are only seldom attained in transactions of wood lots ${ }^{1}$ ). Anyway, an intellingent buyer does not pay for wood lots more than he expects to gain as a competitive return for his money. If the effects of a possible rise of land value in the calculations of the partners in a transaction is eliminated, the rest reflects their opinion of the expectation value of the timber stand.

The interest rate, which more or less consciously is taken as a basis of estimation in transactions of this kind, is to some extent subjective in character. There is always an increasing risk when the period of investment becomes longer; it has been said that "the disagreeableness of being subjected to this uncertainty will be a strongly increasing function of the length of future time which it may have to be endured" (SHACKLE 1958, p. 83). And irrespective of risk, the time preference varies with individuals and the length of waiting time (BoulDING 1955, pp, 831-836). We have above (p. 296) mentioned the discovery of BARRACLOUGH \& GOULD concerning the different time preferences of farmers according to their income level in relation to a certain minimun standard of living, which shows that wealthy farmers have a lower subjective rate of discounting. Davis (1966, p. 326), on the other hand notes that individual and organizational time preferences vary greatly and that lower time preferences may be expected from corporations and the Government than from individuals.

1) The formula is $\mathrm{AR}=\frac{0.0 \mathrm{p} \cdot \mathrm{Vn}}{1.0 \mathrm{p}^{\mathrm{n}-1}}$; where $\mathrm{Vn}$ is the value of harvest cut after $\mathrm{n}$ years and $\mathrm{p}$ the rate of interest. If the discounted value of furure harvest cuts (Vo) is computed, $\mathrm{AR}$ is obtained as well from the formula $\mathrm{AR}=\frac{\left(1.0 \mathrm{p}^{\mathrm{n}} \cdot 0.0 \mathrm{p}\right) \cdot \text { Vo }}{10 \cdot \mathrm{p}^{\mathrm{n}}-1 .}$.

1) Cf. Keltikangas (1962, pp. 12, 14). There is no statistics on the sales and prices of wood lots; nor could statistics, if available, be use fulas evidence since the prices are influenced by the threat of expropriation of land. 
There are, however, social factors which are perhaps still more relevant to the rate of discounting. As Feldstern (1964) has noted, the future income of each individual. . . depends on the savings and investment decisions of the society as a wholen. If the stock of capital increases, the productivity of capital and respectively the rate of interest tends, to decerease in consequence of the dimishing marginal productivity of investments (NEWLYN 1962, p. 93, LuTZ 197, p. 265). An increasing trend in the inclination to save has the same effect (LuTz 1967, p. 265). A foreseen inflation, assuming freedom of interest rates, will raise the rate of interest until it compensates the increased losses to the creditors (SIRKIN 1965, p. 198).

To illustrate this estimation problem, we shall examine three forest site types commonly cleared for cultivation, and different alternatives in the age of timber stands. Of the forest site types in the SF study area, the spruce growing Myrtillus-type (MT) is chosen, in the MF area the pine growing Vaccinium-type (VT), while the Empethrum-Vaccinium type normally covered by pine stand is taken to represent cultivable mineral soil in the southern part of the NE area (Ssm). The calculations are based on the yield tables, on an assumption on the distribution of the yield of different products and on the method of pricing mentioned on p. 333.

In the yield tables, the potential cut is estimated by periods of ten years, in some cases there are also alternatives, between which there are varying thinning operations depending on the planned rotation period. In the case in question, the thinning operations are taken as being carried out according to a plan which gives an optimal rotation period at a 3 per cent interest rate on the money (cf. p. 333). If premature fellings are carried out (which are only assumed at ten yearly intervals) the timber stand corresponds to the figures of the original yield table. No reductions, assumed in the figures, have been made here, and to attain comparability with the figures in Chapter IV, a $20-30$ per cent reduction is necessary.

The high interest rates during inflationary periods are confusing; if such rates are used in computations, the product prices should be estimated in future nominal values. We prefer to use an interest rate which is approximately to the same extent lower the bank loan rate, as the average yearly depreciation of the mark is in per cent. Using the rates of the period $1955-66$, the difference, representing the "net" interest to real values, is 3.34. per cent. If bank deposits rates are used, an interest below 1 per cent is noted.

The loss of forest return caused by premature land clearing is here computed, as stated above, according to three different principles, where first the interest of expectation value, the annuity of the future felling return, or the value growth within the next decade are estimated. The interest on the market value of the timber stand in the beginning ot the period is deducted when estimating the net loss or gain in the first and third case. The annuities of present market values are deducted from annuities of expected future returns. In the valuation the prices of the study period are used as such (Appendix I), except in the NE area where two alternatives are assumed. In Table 21 the annuities for various points in time within the optimum rotation by 10 -years intervals are estimated. The time-bound cost, in this case only taxes and forestry charges, are not deducted. 
According to the figures on the MT-spruce stands in South Finland losses caused by premature felling are largest in the age classes 50-60 years, and represent, as annuities, yearly net losses up to $150 \mathrm{mk}$ per hectare. Measured by interest of expectation value, the permanent yearly loss is highest, about $106 \mathrm{mk}$ in the age class $40-50$ years. The net loss of the value growth is estimated up to $220 \mathrm{mk}$, in the age class $60-70$ years. There is some gain in premature fellings in the net value growth in the last decade, because of the drastic reduction of the timber stand in the last accretion cut.

In the VT-pine stands of Middle Finland, the largest net loss is about $90 \mathrm{mk}$ per hectare and year in annuities, which is found in the age class $40-60$ years. The net loss computed from the interest of the expectation value is at most 69 $\mathrm{mk}$ in the age class $\mathbf{4 0 - 5 0}$ years. The net loss based on value growth is as high as $139 \mathrm{mk}$ per hectare in the age class $60-70$ years, while the last decade also here brings a slight gain.

The figures from the EVT-pine stands in the North Eastern region show to some extent a different pattern, although some net los is evident at least up to the $60-70$ years age class at least if the value growth is used as a criterion. The largest net loss in the interest of the expectation value is about $16 \mathrm{mk}$ per hectare in the age class $40-50$ years, and a little more in annuities in the same period. The interest of the marketable timber stand balances effectively the losses in the interest of expectation values as well as in the annuities, and premature fellings are thus profitable it judged by our criteria. This different pattern is explained largely by the difference of management; the yield tables of the NE region are based on natural stands with no thinning cuts. For our computation, the figures representing the natural removal are used for estimating the thinning returns. Although this is not fully realistic, as small thinnings often bring no profit, this kind of management, though probably with fewer and relatively larger thinnings, is an alternative which may not necessarily prove less productive than the others $\left.^{1}\right)$. The realizable capital bound in the timber stand is, however, relatively large which accounts for most of the difference.

\section{The influence of price increase}

The results of calculations of this kind are certainly affected by the trend in the relative prices of timber. Arising trend is as an alternative assumed in some foreign studies (cf.e.g.p. 13). The changes in price increases have been discussed in an earlier study (PIHKALA 1965, pp. 8-19). The experience over the period $1920-$ 1960 indicates a distinct rise in relative prices, particularly for delivered products. The rather cautious forecasts of the FAO (e.g. 1960) have indicated large increases in the use of wood pulp and the predicted quantities have even been exceeded. In the latest forecasts however, competition from synthetic products is introduced as a factor that may have a revolutionary effect on further developments (RUNEBERG 1968, p. 330).

1) Cf. the studies of Petrerson (1963) on pine stands in Northern Sweden. 
The price trends in the period 1955-1966 (Appendix I and Figure 1, may be used for assessing the future development of relative wood prices in Finland ${ }^{\mathbf{1}}$ ). This period, which falls ouside the so-called Korean boom, forms a relatively complete business cycle so that the trend is not affected by cyclical variations. We have estimated the linear trends for the most relevant relative price series as follows:

Basis year Trend values $(y=a+b x)$

a b

Wholesale price indexes:

Agricultural products

1913

83.4

$+0.67$

Forest

,

159.1

$+1.30$

Export price indexes:

Spruce and pine boards

1913

145.2

$-0.33$
Sulphite pulp, dry, not bleach

,

Butter

Stumpage price indexes:

Saw logs

1955

82.1

3.71

Spruce pulp wood

Pine pulp wood

Fuel wood

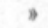

79.8

77.6

71.2

86.4

$-1.95$

$-1.98$

Time wages of forest workers
1955
2.70

3.30

0.78

4.74

Although the export prices of the most important forest products have been decreasing, the domestic wholesale prices have shown a slightly rising tendency. This may be compared with the trend of domestic agricultural prices which have also risen though in a lesser degree, evidently in consequence of increased subsidies. The rise in stumpage prices, in spite of greatly improved wages, has been compar atively larger than in wholesale prices. Improved transport conditions as as other technological development may account for this state of affairs.

Even if we are cautious, we are entitled as an alternative to presume some rise in the future trend in the real prices of forest products. Assuming that the rise is only 5 per cent per decade, we have obtained new values for the losses caused by premature cuts, presented under A in Table 22.

Comparisons with the figures in Table 21 indicate, as is self-evident, considerably higher losses from premature fellings following the rising prices of forestry products. Thus, net losses up to about $130 \mathrm{mk}$ per year in the interest of expectation value, and over $170 \mathrm{mk}$ in annuities are found in the SF main area, and about $70 \mathrm{mk}$ and $110 \mathrm{mk}$ respectively in the MF main area. In the natural stands of the NE (Ssm) area, the net losses are smaller.

As stated above, the results of the computations refer to the yield tables, and thus represent better than average conditions. Reductions, similar to those in Chapter IV (p. 334), are consequently recommended for practical application.

1) See also Pihkala and Lasola, 1973, p. 460.) 
The method presented here has evidently some weaknesses in practical application. One of these is the difficulty of classifying the objects of land use planning into pure types and age classes. It has been pointed out that wide forest areas in Finland are composed of uneven age classes, (cf. p. 307). The wellknown effect of the errors in the selection of the rate of interest, as well as in the forecasts of price developments, engender difficulties to such an extent that a tendency to avoid calculations of this kind is by no means unusual.

However, the examples presented here will, we hope, serve to prove that premature cuttings which are often combined with land clearing are not to be recommended.

Table 22. The interest of expectation value, or annuity, in different age classes, assuming a 5 per cent rise per decade in the deflated price of timber (A), net loss or gain (B), and the differences of net losses or gains (C) compared with the respective figures of Table 21, representing the case of constant real price level of forest produsts, in mk per ha.

\begin{tabular}{|c|c|c|c|c|c|c|c|c|c|}
\hline \multirow{2}{*}{$\begin{array}{l}\text { Age of } \\
\text { stand }\end{array}$} & \multicolumn{3}{|c|}{ MT-spruce, SF } & \multicolumn{3}{|c|}{ VT-pine, MF } & \multicolumn{3}{|c|}{ EVT-pine, NE (a) } \\
\hline & A & B & c & A & B & C & A & B & $\mathrm{C}$ \\
\hline 10 & 76.5 & -76.5 & 17.8 & 43.8 & -43.8 & 10.5 & . & . & . \\
\hline 20 & 98.8 & -98.8 & 19.9 & 56.6 & -56.4 & 11.8 & . & . & . \\
\hline 30 & 127.3 & -122.8 & 21.4 & 73.0 & -63.3 & 12.3 & . & . & . \\
\hline 40 & 160.1 & -127.6 & 21.7 & 91.1 & -72.9 & 4.4 & . & . & . \\
\hline 50 & 186.8 & -124.2 & 20.5 & 103.0 & -65.8 & 6.9 & 29.2 & -20.3 & 7.3 \\
\hline 60 & 199.9 & -102.5 & 17.4 & 126.1 & -64.7 & 11.3 & 36.4 & -12.6 & 8.1 \\
\hline 70 & 197.9 & -57.6 & 12.6 & 127.9 & -36.2 & 8.3 & 45.0 & +2.6 & 9.4 \\
\hline 80 & 158.4 & -13.9 & 7.1 & 105.7 & -9.4 & 4.8 & 56.0 & +12.6 & 10.3 \\
\hline 90 & - & - & - & - & - & - & 70.2 & +19.7 & 10.8 \\
\hline 100 & - & - & - & - & - & - & 88.6 & +20.9 & 10.6 \\
\hline 110 & - & - & - & - & - & - & 107.6 & +20.7 & 9.2 \\
\hline 120 & - & - & - & - & - & - & 132.3 & +11.8 & 6.4 \\
\hline \multicolumn{10}{|c|}{ Annuities } \\
\hline 20 & 113.1 & -113.1 & 22.6 & 64.8 & -64.8 & 13.7 & . & . & . \\
\hline 40 & 207.5 & -165.4 & 28.2 & 118.0 & -94.6 & 5.6 & . & . & . \\
\hline 60 & 340.0 & -174.3 & 29.6 & 214.5 & -110.1 & 19.2 & 41.7 & -14.5 & 9.3 \\
\hline 80 & 618.9 & -54.2 & 27.8 & 413.1 & -36.8 & 18.7 & 72.5 & +16.4 & 13.3 \\
\hline 100 & - & - & - & - & - & - & 150.7 & +35.5 & 12.5 \\
\hline
\end{tabular}




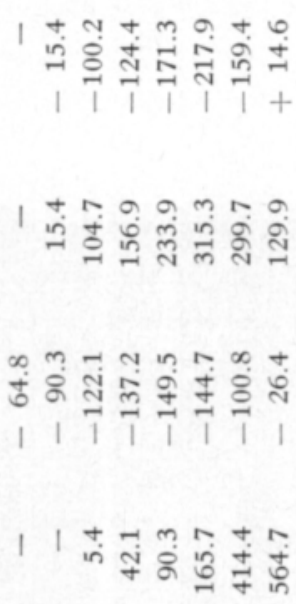

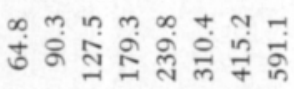

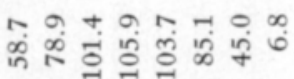

। 1 1 1 1 1 1 ।

1 1 भ ก

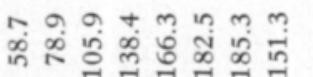

ह̊.

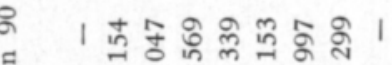

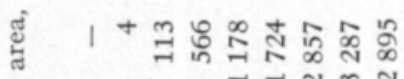

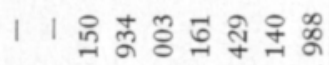

ค่‡

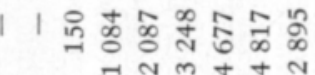

¿

으스이우요융ㅇ

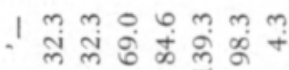

|

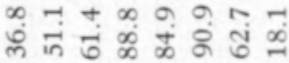

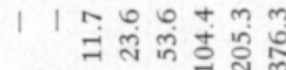

品

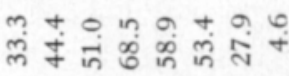

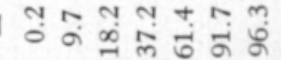

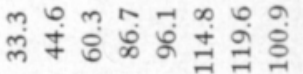

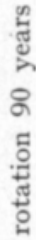

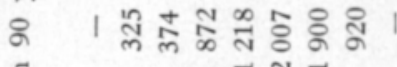

1

। $1 \stackrel{\infty}{m}$ कె

류

$\rightarrow$

苞

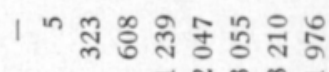
$\rightarrow \mathrm{N} m \mathrm{~m}-$
点 
. J

. . मिं

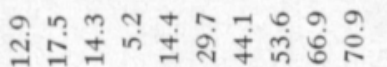

| 1 | 1 | $++++t$

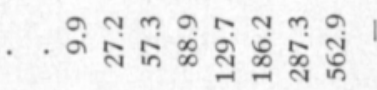

ปิ

กิ สุป I. I 1 + + + +

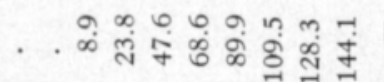

त)

题

Y $m$ ? $m$ ?

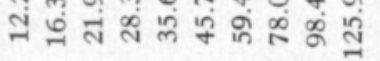

욤

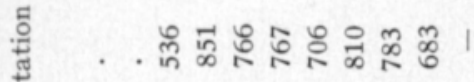

容

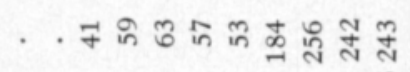

믈

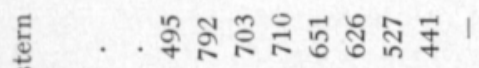

总

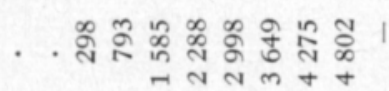

(1)

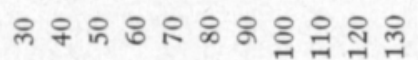

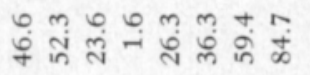

تُ

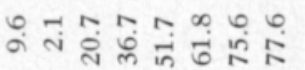

1 $1++++++$

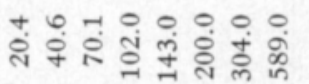

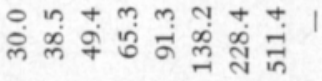

$n=9+9 m \infty \infty$

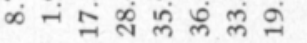

I $++++t+t$

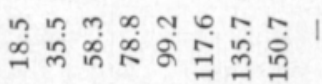

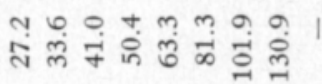

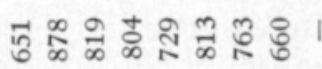

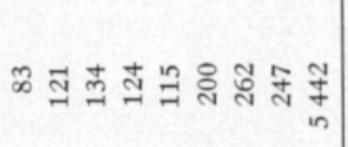

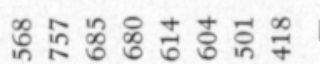

है

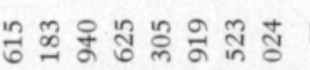

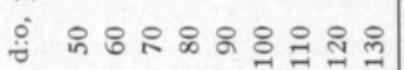

a 


\section{Linear programming approach}

If the aim of the present study is to find a method to estimate the net return or the social output obtained by taking into cultivation more or less of the existing forest land within a certain economic unit, the LP, i.e. linear programming approach has obvious advantages. This method makes it possible to recommend production patterns which maximize the business profits or maximize the social output to the owner and his family, assuming various restrictions, e.g. regarding land area, available capital or hired labour. If an optimum management plan is made first, assuming the existing arable area, and subsequently, permitting deliberate changes in the relative areas of cultivated land and forest, the differences in the economic result variables, when the costs involved in land clearing are also taken into account, indicate the respective advantages or disadvantages of land clearing.

In this method it is essential that the existing production organization is not taken as a starting point, but instead a management plan is made by using the input-output data based on sufficient information of empirical reality. The collection of reliable data is often most difficult in such primary modes of production as agriculture and forestry, where great variations due to natural causes

are common. As relatively small errors may affect to a large degree the optimum plan, the planner has often difficulties in convincing the recipient regarding the adoption of his recommendations.

Many early applications of the LP-method in agriculture were very simple, nor did they take into account the complicated nature of agricultural production especially when combined with animal husbandry. The techniques has greatly improved since (URFF, 1964, pp. 194, 195). The adoption of negative input-output coefficients has made it possible to introduce an increased number of alternative part processes for optimum combinations (CANDLER 1956, p.946, ZAPF 1965. pp. 41, 42). The non-linear method of programming makes it possible to find an optimum in conditions of decreasing marginal returns (YARON and HEADY 1961 , p. 69,70). This method can also be applied when an increasing return is obtained e.g. by a more effective use of an labour when the number of milk cows is increased (ZAPF 1965, p. 60-65). The different levels of mechanization can be taken into account when forming alternative production processes for the same line of production.

In the comparisons of land use for agriculture or forestry, there is no reason to include into agricultural production that part of animal production, which has been produced by feeds produced elsewhere. To some extent, exceptions should be allowed in cases where complementing home produced feeds is necessary, e.g. by protein rich feeds. In the linear programming approach, the appropriate restrictions are, however, necessary, to avoid unrealistic results. 
The nature of capital restrictions has not always been very clear in the application of the LP-method. The inputs in the form of fertilizers, concentrates, etc. assume capital, but the investment is made for a short period and scarcely needs to be taken into account when setting restrictions. The existing building space and other available capacity is generally put in as a restriction. The actual capital restriction is caused by the fact, that the amount of liquid assets may be limited, or that the relation of assets and debts sometimes favours further borrowing and sometimes not. The possibility to obtain loans of a certain amount at a certain interest, and perhaps an additional loan at a higher interest, forms a capital restriction, which limits the various alternatives for development of a better plan.

CANDLER (1956, p. $947 \mathrm{ff})$ has pointed out that capital restrictions can decisively influence the optimum plan, and that the successive inputs of capital by introduction of new activities may vary in their effect to improve the net income and may result in a movement toward a capital optimum or away from it.

In the writer's opinion, capital restriction should refer to the demand of additional capital to fullfil a new production plan. Only if a new pioneer farm were to be established, should the restriction imposed by the possible total investment be considered.

How should the capital value of a timber stand be treated in a programme in which, the alternative use of a certain piece of forest land is to be determined? When the land is cleared for cultivation, the market value of the timber stand is available for investments in agricultural production. In other words, the capital restriction for further activities is correspondingly removed, and thus the value of the timber stand can be added to the existing restriction limit. Such an argument must, however, be discarded. Even the colonist farmers are obliged to pay for timber stands, which often has landed them in debt, and the removal of of this capital value diminishes their possibilities to obtain mortgage loans. Although the financing of new investments may be easier in practice, the restriction of capital resource scarcely can be essentially raised in the case of land clearing.

From the liquidity point of view, the marketable timber stand is more valuable than capital invested in land clearing, buildings and even in machinery. If the land clearing leads to investments of the latter type, the liquidity is weakened and the farmer is no longer in a position freely to make his future decisions.

The application of the LP-method to the problem of optimum combination of agriculture and forestry on a North East Finland (Ssm) pioneer farm is presented in a separate paper (Pihkala \& LASOLA, 1973).

In the course of this study, the applicability of dynamic programming for the problems arising here has been considered (cf. BELLMAN - DREYFus 1964). This method may have advantages for long-term planning, if e.g. the age structure of the timber stand in the forest is uneven, and thus liquidity problems may become more marked during certain future periods, if the condition of existing buildings presumes reconstructions with possible capacity changes at a foreseen future date, or if forecasts of various product prices show distinct trends which alter the relative profitableness of different enterprises. Special cases like these may occur in individual planning, but it has not been found justifiable to present single examples of such planning in this connection. 


\section{Advantage or disadvantage in socio-economic calculations}

The socio-economic advantages of an economic activity can scarcely be exactly measured, unless we approve the direct contribution of the said activity to the national income as such. If this principle is approved, there still remains the drawing of a proper boundary line between the primary and secondary production, and the question of the significance of primary production as a necessary condition of the secondary and to some extent also of the tertiary, i.e. the service production.

It may be advisable to treat the processing and manufacturing industries using the products of primary industries as almost the sole source of raw material combined with the respective primary industries in socio-economic calculations, following the practice already applied in some above-mentioned foreign studies (cf. pp. 297-300). Thus, e.g. the national income earned in the wood-working industries, grain mills, dairies, slaughter-houses and raw sugar factories should be included in the comparative calculations of national income.

It seems also pertinent that the earnings in the transport services in moving the products to the markets are taken into account as far as possible. The same principle would be justified with regard to various other activities connected with the marketing of products, were not the practical difficulties of estimation considerable.

The economic activities in primary and secondary production give rise to a more expanding tertiary production, the more the level of income grows in the former types of production. As in the computations of the national product, the income earned in the latter type is simply added to that of the former types, the increase is double and can scarcly be directly attributed to the first mentioned activities. $\left.^{1}\right)$ However, without a remunerative primary production in the prevailing conditions the the tertiary production may not be possible. The point is should this fact be taken into account when judging the economic advantage of a certain kind of production?

The kind of problems that arise in this connection become clear when one assumes two kinds of primary production which differ not only in the value per area unit but with regard to the relative remuneration of labour, capital and land. One of them yields a low income per hour allowing only restricted spending of the services of tertiary industries. On the other hand, it may distribute income to a larger number of people. The other may be able to pay higher wages, but only to a smaller group of people, this group having, however, more money

1) If e.g. the prices of primary products in a region where the primary production is the main type of production are rising, the national product rises relatively more than the rise of prices that follows as tertiary industries come into existence. 
to pay for services. If tertiary industries are taken into account, the income earned in these balances the differences of the total sum of income in both industries at least to some extent. If the industries are compared, however, the inclusion of tertiary industries may underline too much the comparative advantage of the latter. ${ }^{2}$ )

If the remuneration on land and capital is paid to the persons living inthe region, their effect on the tertiary industries is similar in the case of labour earnings. There are often cases, however, where this part of income is directed to the market centres and does not increase the wealth in the region. This, however, does not alter the character of the problem of comparison within the framework of national economy. - Anyway, it is considered preferable to exclude the tertiary industries from these comparisons.

In the usual method of computing the net national product (net domestic product as it is called in Finnish statistics) two concepts are distinguished: the NNP at it's actual cost and the NNP at market price (STV, 1966, p. 252). The latter differs from the former only by the fact that indirect taxes are added to and subsidies are deducted from the net product. As is well known, the NNP differs from the GNP (gross national product) by the amount of depreciation of the real capital.

The total amount of the Government support to agriculture is not, however, quite clear in calculations like these. For example, the price guarantees granted to agriculture are in different conditions maintained by different methods. To the farmers, the prices of farm products and requisites, together with the volume produced and used, form the main part of their income; in addition certain subsidies, paid on the basis of the cultivated area, the number of cows, etc. bring in some income. The method mentioned here thus corrects the computed income with sums paid from the Treasury e.g. for export subsidies in order to maintain a higher domestic level of prices. Some earlier foreign studies, referred to above, follow however, the principle outlined for the national income calculations (cf. Land Use Study Group 1966, p. 72)

It has been suggested (e.g. NASH 1955, p. 227, McCrone 1962, p. 49, GuLBRANDSEN and LINDBECK 1969, p. 27 and VIITA 1959, p. 11) that the cost of agricultural support should be estimated by valuing the domestic products at prices applicable to the equivalent imported goods, and comparing the total sum thus obtained with the total at normal prices.

This procedure presumes that the subsidies which influence domestic market prices are not taken into consideration separately. The value of the domestic product, thus estimated, would consequently represent the value to the Nation. The subsidies paid in addition to the prices, however, should be deducted and the yield of indirect taxes, not used for support, added, as in the usual method of NNP-computations.

Theoretically this method can be criticised, as nit is virtually impossible to assess the level of market prices if subsidies were removed" (Land Use Study Group, p. 72; cf. also McCrone, p. 18, and Viita, p. 63.) In practice, this method,

${ }^{2}$ ) If a is the income earned in the former, which does not allow purchases of services, and $\mathrm{f}$ the income earned in the latter, while $\mathrm{f}-\mathrm{a}=\mathrm{b}$; and the income earned in the service production $s$ is equal to $b$, the apparent difference $(f+s)-a=2 b$, or double the difference $f-a$. 
Table 23. Estimate on socio-economic income, Net National Product (obtained in conditions of hypothetical free trade price level) caused by activities based on land use, by study areas, per mk hectare.

\begin{tabular}{|c|c|c|c|c|c|c|c|c|c|}
\hline & \multicolumn{3}{|c|}{ SF } & \multicolumn{3}{|c|}{ W } & \multicolumn{3}{|c|}{ MF } \\
\hline & Farm & Transp. & Proc. & Farm & Transp. & Proc. & Farm & Transp. & Proc. \\
\hline Bread grain .... & 68.67 & 2.55 & 14.63 & 16.38 & 0.75 & 4.29 & 8.19 & 0.37 & 2.15 \\
\hline Potatoes .......... & 34.53 & - & - & 38.46 & - & - & 49.17 & - & - \\
\hline Sugar beets ....... & 17.39 & 3.23 & 15.24 & 4.88 & 0.91 & 4.28 & - & - & - \\
\hline Milk ............... & 375.59 & 16.33 & 48.99 & 326.14 & 14.18 & 42.54 & 278.76 & 12.36 & 36.36 \\
\hline Beef ................. & 141.93 & 2.79 & 14.74 & 122.55 & 2.41 & 12.73 & 133.09 & 2.61 & 13.82 \\
\hline \multirow[t]{2}{*}{ Horse days ....... } & 30.24 & - & - & 26.88 & - & - & 45.90 & - & - \\
\hline & 668.35 & 24.90 & 93.60 & 535.29 & 18.25 & 63.84 & 515.11 & 15.34 & 54.49 \\
\hline Fertilizers \& & & & & & & & & & \\
\hline $\begin{array}{l}\text { lime } \\
\text { Feed grain, }\end{array}$ & 86.83 & - & - & 62.80 & - & - & 75.03 & - & - \\
\hline purch. ............. & 11.48 & - & - & - & $\cdots$ & - & 10.58 & - & - \\
\hline Oil cakes, purch. & 15.03 & - & - & 15.40 & - & - & 16.33 & - & - \\
\hline \multirow[t]{2}{*}{ Other $\quad \ldots . . . \cdots \cdots$} & 95.02 & - & - & 102.88 & - & - & 87.75 & - & - \\
\hline & 208.36 & - & - & 181.38 & - & - & 189.69 & - & - \\
\hline Depr. .............. & 127.85 & - & - & 130.58 & - & - & 115.89 & - & - \\
\hline NNP $\ldots \ldots \ldots \ldots \ldots$ & 332.14 & 24.90 & 93.60 & 223.33 & 18.25 & 63.84 & 209.53 & 15.34 & 54.49 \\
\hline Aggregated NNP & - & 450.64 & - & - & 305.42 & - & - & 277.20 & - \\
\hline Man hrs per ha & 301 & - & - & 324 & - & - & 292 & - & - \\
\hline Mk/hour ........... & $1: 10$ & - & - & $-: 69$ & - & - & $-: 71,8$ & - & - \\
\hline
\end{tabular}

Ssm

$\mathrm{Ku}$

Sa

NE

Farm Transp. Proc. Farm Transp. Proc. Farm Transp. Proc. Farm Transp. Proc.

\begin{tabular}{|c|c|c|c|c|c|c|c|c|c|c|c|c|}
\hline Bread grain ....... & 2.5 & 0.09 & 0.54 & - & - & - & - & - & - & - & - & - \\
\hline Potatoes ............ & 30.36 & - & - & 48.87 & - & - & 21.60 & - & - & 31.44 & - & - \\
\hline Milk ................... & 384.79 & 16.73 & 50.19 & 631.58 & 27.46 & 82.38 & 320.39 & 13.93 & 41.79 & 414.00 & 18.00 & 54.00 \\
\hline Beef ........... & 202.35 & 3.98 & 21.02 & 88.35 & 1.74 & 9.18 & 213.75 & 4.20 & 22.20 & 214.60 & 4.22 & 22.29 \\
\hline \multirow[t]{2}{*}{ Horse days } & 67.32 & - & - & 110.16 & - & - & 83.22 & - & - & 75.24 & - & - \\
\hline & 687.87 & 0.80 & 71.75 & 878.96 & 29.20 & 91.56 & 638.96 & 18.13 & 63.99 & 736.28 & 2.22 & 76 \\
\hline
\end{tabular}

Fertilizers \&

\begin{tabular}{|c|c|c|c|c|c|c|c|c|c|c|c|c|}
\hline 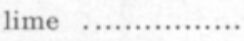 & 155.03 & - & - & 162.46 & - & - & 132.99 & - & - & 147.03 & - & - \\
\hline Feed grain, purch. & 12.83 & - & - & 69.98 & - & - & 38.03 & - & - & 36.00 & - & - \\
\hline Oil cakes, purch. & 26.02 & - & - & 46.29 & - & - & 20.71 & - & - & 24.85 & - & - \\
\hline \multirow[t]{2}{*}{ Other ................ } & 92.57 & - & - & 132.53 & - & - & 93.74 & - & - & 107.40 & - & - \\
\hline & 286.45 & - & - & 411.26 & - & - & 285.47 & - & - & 314.78 & - & - \\
\hline Depr. ............... & 126.41 & - & - & 216.22 & - & - & 133.69 & - & - & 148.25 & - & - \\
\hline NNP ................ & 274.01 & 20.80 & 71.75 & 251.48 & 29.20 & 91.56 & 219.80 & 18.13 & 63.99 & 272.25 & 21.42 & 72.06 \\
\hline Aggregated NNP & - & 366.56 & - & - & 372.24 & - & - & 301.92 & - & - & 370.76 & - \\
\hline Man hrs per ha. & 265 & - & - & 433 & - & - & 296 & - & - & 345 & - & - \\
\hline Mk/hour ............ & $1: 03$ & - & - & $-: 58$ & & - & $-: 74$ & - & - & $-: 79$ & - & - \\
\hline
\end{tabular}


if sensibly applied, could reflect at least the minimum value of current agricultural production. In a country with agricultural surpluses, this method would give the marginal value of the additional unites of output. The method which has been followed in some foreign studies in selecting international price data could, however, be exposed to criticism. Thus, e.g. the valuation of liquid milk used for human consumption, if based on international butter prices, scarcely gives the right idea of its contribution to the national product.

The low prices in the international trade of agricultural products are indirectly dependent on the protectionistic policy of a number of highly developed countries. GulbrandSEn (1969, pp. 47, 182-188) has estimated that a total suspension of agricultural support in the EEC would raise the international price level of agricultural products by $20-30$ per cent. To avoid extreme conclusions, the margin of such magnitude should be added to the international prices in order to obtain data suitable for computations useful to longterm policy.

As the agricultural surpluses are caused to a larger extent by intensification of already existing production than by land clearing, it would be unreasonable to use marginal values in calculations of this kind. We have consequently made our estimations, e.g. on milk prices, assuming an average distribution of milk to processing and direct consumption.

In Appendix VII, the estimation of the socio-economic prices is presented on pp. 380-381. Finnish import and export prices have been used as a basis; corrected by 25 per cent to establish an approximation of the assumed free trade equilibrium price level. The estimation of producer prices of milk turned out to be rather complicated, as the cost of dairies had to be determined and the value of returned skim milk added to the prices. The value of milk consumed in liquid form is taken as such from earlier calculations, and the average producer price of all milk is computed as a weighed average.

Of the prices of requisites used in agricultural production, those of fertilizers were kept under the production cost level by subsidies, while the prices of bought concentrates were influenced by duties or import levies. In our calculations, to obtain socioeconomic prices, the subsidies are added by using the multiplier while the duties of oil cakes are deducted. Feed grain is valued by the prices of an assumed equilibrium price level.

Table 24. Contribution to Net National Product of the activities in forestry, mk per hectare productive forest land.

\begin{tabular}{|c|c|c|c|c|c|c|c|}
\hline & SF & W & MF & $\mathrm{NE}$ & Ssm & $\mathrm{Ku}$ & Sa \\
\hline Stumpage value........ & 75.70 & 43.03 & 47.49 & 12.47 & 21.42 & 10.63 & 10.07 \\
\hline Logging \& hauling ................ & 38.08 & 24.75 & 26.26 & 11.61 & 16.00 & 11.76 & 9.54 \\
\hline Total on farm .................. & 113.78 & 67.78 & 73.75 & 24.08 & 37.42 & 22.39 & 19.61 \\
\hline Transport .............. & 10.83 & 8.19 & 13.45 & 7.57 & 10.13 & 8.58 & 5.89 \\
\hline \multicolumn{8}{|l|}{ Processing } \\
\hline saw mills .............. & 26.96 & 15.19 & 17.66 & 8.36 & 13.51 & 7.02 & 7.16 \\
\hline pulp mills . ...................... & 34.98 & 21.29 & 23.03 & 10.65 & 13.47 & 11.52 & 8.69 \\
\hline paper industry ................. & 1.96 & 1.20 & 1.29 & 0.60 & 0.76 & 0.65 & 0.50 \\
\hline Total outside farm ............ & 74.73 & 46.67 & 55.43 & 27.18 & 37.87 & 27.77 & 22.24 \\
\hline
\end{tabular}


The contribution of transports and industrial processing to the NNP is estimated using the data presented in Appendix VII. The national averages are applied here, except when estimating the part of transport of wood material and products, which are differentiated between the main study areas.

Those contributions are first computed per unit of material produced in primary production. On the basis of the figures obtained, an estimation of the total contribution of the activities in land use to the NNP is made. The values are computed per hectare of land, using the volumes estimated in Chapter IV, and in addition, in primary production, per effective working hour. This estimation is presented in detail in Tables 26 and 27.

Summarizing the figures of these tables, the following values of the NNP per hectare are computed for the main study areas and the three North East Finland subareas:

\begin{tabular}{|c|c|c|c|c|c|c|c|}
\hline \multirow[t]{2}{*}{$\mathrm{NNP} \mathrm{mk} / \mathrm{ha}$} & SF & W & MF & NE & Ssm & Ku & $\mathrm{Sa}$ \\
\hline & \multicolumn{6}{|c|}{ Farm activities } & \\
\hline Primary prod. .................... & 332 & 223 & 210 & 272 & 274 & 251 & 220 \\
\hline 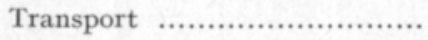 & 25 & 19 & 15 & 21 & 21 & 29 & 18 \\
\hline \multirow[t]{3}{*}{ 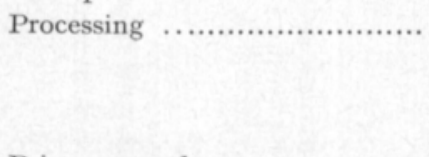 } & 94 & 64 & 54 & 76 & 72 & 92 & 76 \\
\hline & 451 & 305 & 277 & 371 & 367 & 372 & 302 \\
\hline & \multicolumn{6}{|c|}{ Forest activities } & \\
\hline Primary prod. ...................... & 114 & 68 & 74 & 24 & 37 & 22 & 20 \\
\hline Transport . .......................... & 11 & 8 & 13 & 8 & 10 & 9 & 6 \\
\hline \multirow[t]{2}{*}{ Processing . } & 64 & 38 & 42 & 19 & 28 & 19 & 16 \\
\hline & 189 & 114 & 129 & 51 & 75 & 50 & 42 \\
\hline
\end{tabular}

Computed per working hour in primary production, the NNP is (assuning no deductions for interest on capital), mk:

$\begin{array}{lcrrrrrr} & \text { SF } & \text { W } & \text { MF } & \text { NE } & \text { Ssm } & \text { Ku } & \text { Sa } \\ \text { In farm activities ….............. } & 1.10 & -.69 & -.72 & -.79 & 1.03 & -.58 & -.74 \\ \text { In forest activities ................ } & 4.76 & 4.34 & 4.49 & 3.70 & 4.30 & 3.29 & 3.70\end{array}$

Finally the values of the NNP are computed for the average study farms in primary production only. The following figures are then obtained:

\begin{tabular}{lccccccc} 
NNP mk/farm & SF & W & MF & NE & Ssm & Ku & Sa \\
Farm activities ......... & 2973 & 1369 & 1645 & 1514 & 2159 & 772 & 1510 \\
Forest activities .......... 1641 & 2701 & 3190 & 2515 & 3220 & 1739 & 2500 \\
\cline { 2 - 8 } & 4614 & 4070 & 4835 & 4029 & 5379 & 2511 & 4010 \\
Total ................... & 4.679 & 2424 & 2867 & 2670 & 2948 & 2023 & 2798 \\
Working hours, total & 2979 & 1.68 & 1.69 & 1.51 & 1.82 & 1.24 & 1.43
\end{tabular}

The income from forestry, in fact, compensates the agricultural income to such an extent that the total income does not greatly vary, in spite of large differences in farm product NNP values. In fact, in remote regions with large farm forest areas, the NNP per labour hour exceeds that obtained in predominantly agricultural areas. It should be once more underlined that these figures include the remuneration to all factors of production. 


\section{Summary}

In this study, computations on the relative advantages of land use for agricultural and forest production are made, on the basis of data collected from samples of so-called "cold" colonist farms established rather recently on forest or peat land. The observations were made mainly during the period 1959-63, and the price structures of this period are applied. Four hundred study farms in four main study areas, each with $3-7$ subareas, were chosen for this study project. Their location is shown on the map on page 310 , more detailed information is published by LAsola (1965). The systematic observations were limited to the cultivated areas, crop yields, livestock numbers, milk deliveries and use of fertilizers, and in regard to forests, to the forest type and age structure of the timber stands. Expected information on the qualities of forests taken into agricultural use proved to be rather poor so that the results on the loss of forestry income in connection with land clearings have more a character of hypothetical examples than of actually observed averages.

The cost calculations of farm production are based on comparable data from book-keeping farms; the labour hours, however, are estimated using available information on effective working time required for different operations within enterprises. The same principle was followed in the forest calculations, where natural stands treateds with thinning and accretion cuts were assumed, as far as information was available. In estimating the volume of different products available, yield tables and other results of forest research work were used; when setting the prices, a somewhat arbitary differentation between diameter classes was applied. The calculations were made assuming "normal forest" conditions and optimum rotation periods, which are selected by applying the marginal rate equalization method (p. 333). In the Northern study area, where a 3 per cent interest is too high to give a positive land rent under rational rotation periods, the lenght of the rotation used in State forestry plans is applied. Some simplification has been necessary, e.g. only coniferous timbers stands have been taken into account.

In calculations for private economy, the average net returns, labour income and land rent were estimated and presented in Tables 14 and 19 (pp. 327,334, summarised also on p. 338), by main study areas and the three North Eastern Finland subareas. In judging the economic advantage of land clearing, these figures are relevant providing that we can accept them as representing a state of stabilized equilibrium between both alternative land uses. This being the case the advan- 
tage or disadvantage of land clearing becomes clear when the land rent in both uses is compared; the interest on the costs of land clearing is in this connection implicitly taken into account as a cost item. This is, however, valid only on the condition that the opportunity cost of the resources can be properly estimated. Two alternative values for labour hour, viz. average wages paid in rural industries (alt. 1) or the average wages paid to hired farm workers (alt. 2) are here applied.

As in some other investigations, the land rent in agricultural land use proves here to be negative with the prevailing opportunity cost of labour and the existing small size farm (p. 312) structure. The land rent in forestry, if a 3 per cent interest on the market value of a timber stand is assumed, is positive in the South and Middle Finland study areas, decreasing, however, towards the North and becoming slightly negative in North East Finland. The labour income, though small per working hour, is nevertheless many times larger per hectare in agricultural production than in forestry.

Land clearing presumes certain investments which vary according to the used method and the character of soil, as well as the age and density of timber stand. In the conditions prevailing during the study period, this cost could be estimated withim the limits of $800-1300 \mathrm{mk}$ per hectare; on peat land, however, it was somewhat lower. If land clearing is subsidized, the costs of investment for private economy are lower. The interest on the capital invested in land clearing is a cost item that must be taken into account in the decisions on the possible use of forest land for agricultural purposes.

Extension of the cultivated area of a farm by land clearing improves the economics of scale of agricultual production, and the advantages of land clearing should, therefore, generally be judged by the marginal analysis. An attempt at such an analysis is made in Chapter $\mathrm{V}$. The net return and land rent values thus obtained are positive and larger than in average calculations. - No attempt to estimate marginal values in forestry have been made in this connection. The benefits of linear programming in the solving of the problem are discussed in Chapter VII. An application of this method has been presented elsewhere.

A particular problem in the estimation of the comparative advantage or disadvantage of land clearing for agricultural use, is the eventual loss of forestry production value. As a measure for this the average stumpage value of the rotation period can sometimes be recommended as such, e.g. the stands are when unevenly aged. In most cases, where evenly aged stands of different age and development classes are cut for land clearing, the loss or gain in value is dependent on the stage of maturity. For the the purpose of estimating the loss, or, to use another expression, the opportunity cost, three alternative value criteria are adopted: interest of expectation value, annuity of future income, and value growth during the following decade. The yearly net loss (or, in some cases, gain) is obtained when the respective interest or annuity of the market value of the timber stand is deducted.

Yearly net losses of value, presented in Table 21, pp. 352-353, vary largely in stand of different ages. Thus e.g. in the site type MT, in the SF main area, where the land rent is on an average $56 \mathrm{mk}$ per hectare, the "permanent" net loss during the successive decades of the rotation period varies within the limits $7-106 \mathrm{mk}$, and the "periodicn loss in annuities, from 26 to $150 \mathrm{mk}$ per hectare. 
The net loss in value growth can rise up to $218 \mathrm{mk}$ per hectare. In the site type VT, in Middle Finland, with an average land rent of $29 \mathrm{mk}$, the net losses can rise up to $69 \mathrm{mk}$ in interest, $89 \mathrm{mk}$ in annuities, and $139 \mathrm{mk}$ in value growth. In the Ssm subarea the value losses are much smaller; the figures, however, have been computed from natural stands with scarce thinnings and relatively large standing timber capital. The figures here are not really comparable with those used in average calculations, as the values here are based on the yield tables without correetions (Appendix VI, cf. p. 379.)

In the projections of forestry returns, the difficulties in the prediction of future price trends constitute a weak point. These difficulties are discussed in Appendix I, and certain forecasts are made with reservations. In Table 22, p. 351 an assumption of a 5 per cent rise in the deflated timber prices per decade has been adopted as a basis, and corresponding computations of value loss in land clearing have been made.

Although a large part of the forest land cleared on study farms is low producing swamp land (cf. Table 17, p. 331), the figures in the first three columns of Table 18, p. 331, indicate that a relatively large part of the fields of the study farms have been established on the stands in a thinning stage or on other premature stands which from the economic point of view are not to be recommended for land clearing.

The problems of the socio-economic advantages of land clearing are discussed in the last Chapter. Some questions of principle in calculations like these have not yet been finally solved. Thus the inclusion of secondary and tertiary industries in the calculations, and the prices applied in a system of protectionistic policy, have not in the literature part been presented in a uniform manner. In this study the world market prices were not adopted as a basis of production values, neither were the protected home market prices used in this way. In the calculations presented in Chapter VIII, a hypothetical free trade price level is assumed. An approximation of it, based on some Swedish estimations on the effects of the removal of protectionistic measures within the European Economic Community, is accepted for the calculations of the socio-economic income (NNP) in agricultural primary production. In the calculations on forestry, the prevailing unprotected prices are applied as such. The NNP earned in transpo rtation and processing or manufacturing operations is estimated using the average factor costs in transport and manufacturing industries. The estimations of the NNP are brought to the wholesale level of products, and no attempts have been made to taken into account the income from tertiary production. The results are summarized in Tables 23 and 24, pp. 358-59. It seems natural that in the socio-economic comparisons of land use, at least the NNP earned in secondary production should generally be taken into account. 


\section{REFERENCES}

Abetz, K. 1960. Zur Struktur und Betriebswirtschaft bäuerlichen Betriebe mit Wald (im Aufforstung landwirtschaftlicher Grenzböden). Arbeiten der DLG, Bd 61: 12-35. Frankfurt a. M.

Anvendelse av jord til jordbruks- eller skogsbruksproduktion. Rapport fra et samarbeidsteam. 1959. Norges Landbruksvitenskaplige Forskningsråd. 36 p. Oslo.

Barraclough, S. \& Gould, E. M. 1955. Economic Analysis of Farm Forest Operating Units. Harvard Forest Bulletin 26, 145 p. Petersham, Mass.

Bellman, R. E. \& Dreyfus, S. E. 1962. Applied Dynamic Programming. XXII + 363 p. Princeton, N. J.

BJorÅ, E. 1962. Garden og gardskogen. Norges Landbruksøkonomiske Institutt. Saermeld. 24. 94 p. Oslo.

Boulding, K. E. 1955. Economic Analysis. 3. Ed. XX +905 p. London.

Buttrick, P. L. 1948. Forest Economics and Finance. 2. Ed. XVIII +484 p. New York.

Byman, R. 1967. Asutustilojen metsätaloudesta. Asutushallinto 1917-1967: 71-80. Helsinki.

CAJAnder, A. K. 1909. Ueber Waldtypen. AFF 1. IV + 175 p. Helsinki.

CAJANDER, E. K. 1933. Tutkimuksia Etelä-Suomen viljelyskuusikoiden kehityksestä. (Referat: Untersuchungen über die Entwicklung der Kulturfichtenbestände in Süd-Finnland.) MTJ 19,3. 101 p. Helsinki.

CAndler, W. 1956. A Modified Simplex Solution for Linear Programming with Variable Capital Restrictions. Journal of Farm Economics 38,4: 940-955.

Coutu, A. J. \& Ellertsen, B. W. 1960. Farm Forestry Planning through Linear Programming. TVA, Division of Forestry Relations. 31 p. Norris, Tennessee.

Databok för driftsplanering. Lantbrukshögskolans meddelanden. Ser. B, 1. Uppsala 1963.

Davis, K. P. 1966. Forest Management: Regulation and Valuation. 2. Ed. X +519 p. New York.

DUERr, W. A. \& Bond, W. E. 1952. Optimum Stocking of a Selection Forest. Journal of Forestry 50: 12-16.

Duerr, W. A. 1960. Fundamentals of Forestry Economics. XII +579 p. New York.

Ehlers, E. 1968. Kuparivaara, Puolakkavaara, Jouttiaapa. Esimerkkejä nykyisestä asutuksesta Pohjois-Suomessa. (Summary: Examples of contemporary agricultural colonisation in North Finland.) AA 21,3: 9-16.

Ellertsen, B. W. \& Le Roy Rogers 1965 a. Evaluation of Forestry Opportunities on Farms in the Beech River Watershed. TVA, 35 p. (Stencil):

- - \& Le Roy Rogers 1965 b. Guide to Planning Farm Forestry Activities on Coastal Plain and Associated Soils in West Tennessee and Adjoining Areas. TVA, 44 p. (Stencil).

Elstrand, E. 1961. Jord nyttet til jordbruk eller skogbruk. Norges Landbruksøkonomiske Institutt* Saermeld. 31. 86 p. Oslo.

- - _ \& BJorÅ, E. 1964. Bruksverdier i jord- og skogbruk. Norges Landbruksokonomiske Institutt. Saermeld. 31, 86 p.

ENDREs, M. 1911. Lehrbuch der Waldwertrechnung und Forststatik. 2. Aufl. X +308 p. Berlin.

Feldstein, M. S. 1964. The Social Time Preference Discount Rate in Cost Benefit Analysis. The Economic Journal 74: 360-379. 
A Finnish Study Group 1969: Comparative Advantage or Disadvantage of Land Clearing. Research Reports of the Institute of Agricultı ral Policy, 16, $161 \mathrm{p}+6$ appendices \& maps. Mimeo. Helsinki.

Gulbrandsen, O. \& LindBeck, A. 1969. Jordbruksnäringens ekonomi. (Summary: The Economics of the Agricultural Sector.) 280 p. Uppsala.

Heady, E. O. 1952. Economics of Agricultural Production and Resource Use. VIII $+850 \mathrm{p}$. New York.

Heikurainen, L. 1959. Tutkimus metsäojitusalueiden tilasta ja puustosta. (Ref: Ueber waldbaulich entwässerte Flächen und ihre Waldbestände in Finnland.) AFF 69. 279 p. Helsinki.

Helander, A. B. 1939. Onko viljelysmaan ja metsän välinen kilpailu kasvanut ja mihin se johtaa? (Zusammenfassung: Lässt sich die Anbaufläche in Finnland auf Kosten des Waldes vergrössern?) Kansantaloudellinen Aikakauskirja 35,2: 105-130, 201-202. Helsinki.

HJELM, L. 1956. Undersōkning rörande jord- och skogsbrukets relativa lönsamhet. (Sum mary: The Relative Profitability of Agriculture and Forestry.) Meddelanden från jordbrukets utredningsinstitut 2,56: 69 p. Stockholm.

Holopainen, V. 1967. 60-luvun metsäpolitiikka. 156 p. Porvoo.

Håndbog for Driftsplanlaegning. Landbruksministeriets Driftsøkonomiudvalg. 5. ed. Landbrugets Informationskontor. 138 p. København. 1966.

ІнамиотіLA, R. 1968. Viljelijöiden työtulojen taso kirjanpitotiloilla 1956-1965. (Summary: Labour income level of farmers on Finnish book-keeping farms in 1956-1965.) Maatalouden taloudellisen tutkimuslaitoksen julkaisuja 10. 172 p. Helsinki.

Ilvessalo, M. 1962. Suomen vuosien 1939-40 ja 1941-44 sotien jälkeinen asutustoiminta metsätalouden kannalta. (Ref: Die finnische Siedlungstätigkeit nach den Kriegen 1939-40 und 1941-44 vom Standpunkt der Forstwirtschaft.) MTJ 56,4. 184 p. Helsinki

Ilvessalo,Y. 1920. Tutkimuksia metsätyyppien taksatoorisesta merkityksestä nojautuen etupäässä kotimaiseen kasvutaulujen laatimistyōhön. IV $+157+51+33$ p. Helsinki.

- - 1937. Perä-Pohjolan luonnon normaalien metsiköiden kasvu ja kehitys. (Summary: Growth of natural normal stands in Central North Suomi.) MTJ 24,2. 168 p. Helsinki.

- - 1957. Suomen metsät metsänhoitolautakuntien toiminta-alueittain. Valtakunnan metsien inventoinnin tuloksia. (Summary: The forests of Finland by forestry board districts. Results of national forest inventory.) MTJ 47,3. 128 p. Helsinki.

- - 1967. Luonnonnormaalien metsiköiden kehityksestä Kainuussa ja sen lähiympäristössä. (Summary: On the development of natural normal stands in South-eastern NorthFinland.) AFF. 81,5: 1-85.

JÄNNES, J. 1939. Uudisviljelystä vai metsänparannusta? Maaseudun Tulevaisuus, 14. 1. 6. 2. 1939.

Jergensen, F. 1956. Konkurranseforholdet mellom jordbruk og skogbruk sett i relasjon til den nya jordloven. Norsk Skogbruk 13:433-443.

Kaitera, P. 1939. Metsänparannus ja uudisraivaus. Maaseudun Tulevaisuus 21, 22, 23. 2. 39.

KALlıo, K. 1957. Käenkaali-mustikkatyypin kuusikoiden kehityksestä Suomen lounaisosassa. (Summary: On the development of spruce forests of the Oxalis-Myrtillus site type in the South-West of Finland.) AFF 66. 155 p. Helsinki.

KAUKONEN, T. 1956. Ravioskorven asutusalue. AA 9,1:3-6.

Keltikangas, V. 1962. Normaalimetsän kannattavuussadannes ja finanssinen kiertoaika. (Summary: The concept of profitability in the normal forest and the financial rotation.) MTJ 55,24. 16 p. Helsinki.,

Krvivuori, L. 1958. Taxation of agriculture and farm forestry in Finland. (Stencil). Central Union of Agricultural Producers. Helsinki.

Korvisto, P. 1959. Kasvu- ja tuottotaulukoita. Growth and yield tables. MTJ 51,8. 49 p. Helsinki.

Komiteanmietintō (Committee report) 1957. Asutustoiminnan tarkoituksenmukaisuutta selvittelevän komitean mietintö. (Report of Committee set up to determine the utility of settlement operations.) Komiteanmietintö N:o 6. Helsinki. 
Komiteanmietintö (Committee report) 1962. Maatalouskomitean mietintö. (Report of the Committee on Agriculture). Komiteanmietintö N:o 6. Helsinki.

KroG, P. 1954. Jordbruk eller skogsbruk. Nordisk Jordbruksekonomisk Tidskrift 4,1: 7-11.

LAsolA, T. 1965. Peltokasvien sadoista ja satomääriin vaikuttaneista tekijöistä ns. kylmillä asutustiloilla v, 1959-1963. (Summary: On the crop yields and some factors affecting these on s.c. cold farms, 1959-1963.) AAF 106. $168+$ XXII p. Helsinki.

LEDJE, I. 1963. Jord- och skogsbruksföretagets planering. Meddelanden från ekoncmiska institutionerna. Lantbrukshögskolan. 126 p. Uppsala (Mimeo).

LiNDFORs, J. 1964. Metsäteollisuuden puuraaka-aineen kaukokuljetukset vuosina 1959-1961 Suomen Puutalous 46, 21-26, 45-49, 88-97, 148-157, 210-219.

Linnamies, O. 1959. Valtion metsät sekä niiden hoidon ja käytön yleissuunnitelma. Vuosien 1951 - 55 inventoinnin tuloksia. (Summary: The state forests of Finland and a general management plan for them based upon an inventory made in 1951-55). AFF 68,5. 225 p. Helsinki.

Lutz, F. A. 1967. Zinsteorie. 2. Ed. 288 p. Zürich, Tübingen.

Maaseudun kulutustutkimus 1959/60. Rural Consumption Investigation. STV XXXII: 24. Helsinki 1962.

MacGregor, J. J. 1959. Economics and the Use of Land for Forestry. Unasylva 14,2: 61-64.

$\ldots-1962$. Forestry as a Competitor for Land; Some Problems in Land-use Decisions. Eighth British Commonwealth Forestry Conference 1962. 11 p. London.

Marttila, P. J. 1939 a \& b. Uudisraivauksen ja metsänparannuksen vertailu. Maaseudun Tulevaisuus 18. 2. \& 21. 2. 1939.

McCrone, G. 1962. The Economics of Subsidising Agriculture. 189 p. London.

MEAD, W. R. 1951. The Cold Farm in Finland. Resettlement of Finland's Displaced Farmers. The Geographical Review 41,4: 529-543.

Mıкоц, P. 1966. Alikasvosten merkitys metsien uudistumisessa. (Summary: Significance of the undergrowth in reforestation) MAL 83, 1:4-7, 16.

МӒкı, V. 1955. Tönnön asutusalue. AA 8,4:3-6.

NAsh, E. F. 1955. The Competitive Position of British Agriculture. Journal of Agricultural Economics, Vol. XI,3: 222-234.

Newlyn, W. T. 1962. Theory of Money. IX +171 p. Oxford.

NYYSSöNEN, A. 1954. Hakkauksilla käsiteltyjen männiköiden rakenteesta ja kehityksestä. (Summary: On the structure and development of Finnish pine stands treated with different cuttings.) AFF 60. 194 p. Helsinki.

- - 1958. Kiertoaika ja sen määrittäminen. (Summary: Rotation and its determination.) MTJ 49,6. 87 p. Heisinki.

OsarA, N. A. 1948. Maatilametsälön taloussuunnitelma 69, p. Helsinki.

Osuusmeijerien liiketilasto. Helsinki 1961.

Pakкanen, A. S. 1956. Egyptinkorven asutusalue. AA 9,3:15-17.

Pellervon Kalenteri. Helsinki. 1959-1963.

Petrini, F. 1964. Competition between Agriculture and Forestry under Swedish Conditions. Lantbrukshögskolans Annaler, Vol. 30. 333 p. Uppsala.

Petterson, H. 1963. Barrskogens värdeproduktion. (Summary: Yield Value of Coniferous Forests.) Meddelanden från Stantens Skogsforskningsinstitut 52, 1. 510 p. Stockholm.

PihkalA, K. U. 1956. The Land Settlement Program of Finland. Land Tenure (Proceedings of the International Conference on Land Tenure and Related Problems) p. 453-457. Madison, Wis.

- - 1965. Possibilities of Comparing Land Use for Farming and Forestry. Acta Agriculturae Scandinavica. Supplementum 14. 56 p. Stockholm.

- - \& Lasola, TAPANi 1973. Kainuulaisen uudistilan edullisin suuruus ja tuotantosuunta. (Summary: On the optimum size and combination of agricultural and forestal activities of a typical North-East Finland pioneer farm.) MA, 45: 325-460.

Prices of agricultural products and fertilizers in Europe 1961/1962. FAO. Geneva.

PoiJärvi, I. 1934. Kokeita AIV-rehulla. (Referat: Versuche mit A. I. V.-Futter.) Valtion maatalouskoetoiminnan julkaisuja 63. 143 p. Helsinki. 
PUUstıäRvi, V. Eri boniteettiluokkien ja suotyyppien tuottokyvystä paikalliskokeiden antamien tulosten valossa. (Summary: On the productivity of the different degrees of land quality, and bog types, in the light of results produced by local experiments.) Suo 11. $15-6: 86-91$.

Rautatietilasto 1961. (Railway Statistics 1961) SVT XX. Helsinki 1963.

Report on the Land Use Study Group. The Department of Education of Science. X $+110 \mathrm{p}$. London.

Runeberg, L. 1968. Metsătalous ja synteettisten aineiden esiinmarssi. MA 85,11: 314-330. RöNry, A. H. 1958. Luhinsalon asutusalue. AA 11,2: 9-11.

SAARI, E. 1937. Ehdotus käytännölliseksi ja yksinkertaiseksi tuloksenlaskentamenetelmäksi. (A proposition for a practical and simple computation of business results.) MAL 8: 173-177.

SANDQvist, E. 1963. Storleksfaktorn i jordruket. Meddelanden från ekonomiska institutionerna. Lantbrukshögskolan. 99 p. Uppsala. (Mimeo).

Sснаскце, G. L. S. 1958. Time in Economics. 111 p. Amsterdam.

SEPPÄLÄ, K. 1969. Kuusen ja männyn kasvun kehitys ojitetuilla turvemailla. (Summary: Post-drainage growth rate of Norway spruce and Scotch pine on peat.) AFF 93. 89 p. Helsinki.

SIPILÄ, M. 1946. Maatalouden työajan käyttö ja työntutkimus. (Summary: Utilization of Working Hours and Efficiency Study in Agriculture.) AAF 66. 496 p. + 127 appendices. Helsinki.

- - 1949. Kotieläintalouden rationalisointi. I. Tutkimuksia ajankäytöstä erisuuruisten karjojen hoitotyössä. (Summary: Rationalization in live-stock husbandry. I. Research on the use of labour in the herds of different sizes.) Työtehoseuran julkaisuja 57. 80 p. Helsinki.

Sirkin, G. 1965. Introduction to Macroeconomic Theory. $\mathrm{X}+278$ p. Homewood, Ill.

SIRÉN, G. 1955. The development of spruce forest on raw humus sites in northern Finland and its ecology. AFF 62, 4. 408 p.

Suomen osuusmeijerien liiketilasto 1961. (Statistics of cooperative dairies.) Valio, Meijerien keskusosuusliike. Helsinki.

Suomen tilastollinen vuosikirja (STV). Statistical Year Book of Finland. Helsinki.

Tapion taskukirja. Helsinki.

Teollisuustilasto 1961. (Industrial Statistics of Finland 1961.) SVT XVIII A: 77.

Thomson, A. P. \& Grainger, M. B. 1961. Some bases for comparing the relative economics of farming and forestry in New Zealand. The New Zealand Journal of Forestry, VIII, 3: 440-455. Napier.

Thormodsaeter, A. \& Elstrand, E. 1960. Driftskombinasjonen jordbruk-skogbruk. Analyse og plan for gardsbruk i Agder. Norges Lantbruksøkonomiske Institutt. Saermelding nr. 17. 120 p. Oslo.

v. Thünen, J. H. 1875. Der isolierte Staat in Beziehung auf Landwirtschaft und Nationalökomie. 3 Aufl. XXIII + VIII $+400+288+444+144$ p. Berlin.

Tilastoa Suomen karjantarkkailuyhdistysten toiminnasta (TSK). (Statistics of the activity of milk recording societies in Finland) Helsinki.

Treloar, D. W. G. \& Morison, I. G. 1962. Economic Comparisons of Forestry and Agriculture. Institute of Agriculture, University of Western Australia. Agricultural ecconomics Research Report. 82 p. Perth.

Trist, P. J. O. 1948. Land Reclamation. 178 p. London.

Tutkimuksia Suomen maatalouden kannattavuudesta (TSMK). (Investigations on the profitability of agriculture in Finland.) 1961/62. Maatalouden taloudellisen tutkimuslaitoksen julkaisuja, 5, Helsinki 1964.

Tutkimustulokset havaintotilatoiminnasta asutustiloilla 1952/53, 1953, 1954, 1955, 1956, 1957, 1958, 1959. (Study results from pioneer farms.) Maatalousseurojen Keskusliiton julkaisut 434, 438, 444, 469, 480, 483, 489. Kajaani.

v. URFF, W. 1964. Produktionsplanung in der Landwirtschaft. Frankfurter Wirtschafts-u. Sozialwissenschaftliche Studien 11, 318 p. Berlin.

VAlmari, A. 1957. Über die edaphische Bonität von Mooren Nordfinnlands. AAF 88,1. 126 p. 
Virta, P. 1959. Suomen maatalouden ja teollisuuden tuotantokustannushinnat verrattuna kansainvälisen kaupan hintoihin vuosina 1953-1958. (Summary: Factor cost prices in Finnish agriculture and industry compared with international market prices 19531958.) Suomen Pankin Taloustieteellisen Tutkimuslaitoksen julkaisuja B: 22.155 p. Helsinki.

Vuокı́A, Y. 1956. Etelä-Suomen hoidettujen kuusikoiden kehityksestä. (Summary: On the development of managed spruce stands in Southern Finland.) MTJ 48,1. 138 p. Helsinki.

- - 1967. Eriasteisin kasvatushakkuin käsiteltyjen männiköiden kasvu- ja tuotostaulukot maan eteläistä sisäosaa varten. (Summary: Growth and yield tables for pine stands treated with intermediate cuttings of varying degree for southern Central Finland.) MTJ 63,2. 123 p. Helsinki.

Walker, K. R. 1956. The Forestry Commission and the Use of Hill Land. Scottish Journal of Political Economy, Vol. 7: 14-35.

WEINSCHENCK, G. 1966. Recent applications of quantitative research in agricultural economics. Proceedings of the 12th International Conference of Agricultural Economists. p. 92114. London.

Westermarck, N. \& Melén, A. 1962. Praktisk driftsplanläggning. Svenska Lantbrukssällskapens Förbund. Ser, B, 28. 153 p. Borgå.

Wood: World trends and prospects. FAO. Rome 1967.

YARON \& HEAdy. 1961. Approximate and Exact Solution to Non-Linear Programming Problem with Separable Objective Function. Journal of Farm Economics 43,1: 57-70.

ZAPF, R. 1965. Zur Anwendung der linearen Optimierung in der landwirtschaftlichen Betriebsplanung. Berichte über Landwirtschaft. N F. 179. 102 p.

\section{Selostus}

\section{Metsämailla suoritettujen uudisraivausten taloudellisuudesta}

\section{K. U. Pihkala}

Tutkimusselostuksessa käsitelläan tehtävän määrittelyn jälkeen aikaisempia, maan maataloudellisen ja metsätaloudellisen käytön taloudellisia vertailuja, jolloin erityistä huomiota on: kiinnitetty menetelmiin. Eräitä lukuja tällaisista tutkimuksista on vertailevasti esitetty taulukossa 1, p. 305.

Varsinaisen tutkimuksen aineisto on kerätty $1959-63 \mathrm{n}$. neljältä sadalta metsämaalle perustetulta asutustilalta neljältä eri pääalueelta Suomessa (vrt. kartta s. 310). Perustiedot maataloustuotannosta koskevat lähinnä satomääriä ja maidon toimituksia meijereihin, joiden pohjalta eräiden täydennysarviointien jälkeen ja käyttäen hyväksi alueellisia hintatietoja ja kirjanpitotilojen keskimääräisiä kustannuslukuja on arvioitu maatalouden antama todennäkőinen kansantaloudellinen tulo (social output), puhdastuotto (taxable net return) ja maankorko (land rent) hehtaaria kohden. Viimeksi mainittuja laskettaessa on tehollisen työn hinnoittelussa sovellettu kahta vaihtoehtoa: 1. maaseudun teollisuustyöntekijäin 2. palkalla tyőskentelevän maataloustyöntekijän aikayksikköä kohden saama ansio. Metsän tuottoa koskevat arviot perustuvat osaksi tutkimustiloilla suoritettuihin havaintoihin metsätyypeistä ja puustosta, osaksi kasvu- ja tuottotaulukoihin. Keskimääräiset hakkuut oletetun edullisimman kiertoajan kuluessa on arvioitu ja hinnoiteltu puutavaralajeittain, ja myös puun korjuusta saatava työansio on arvioitu. Päätulokset arvioista on esitetty neljän pääalueen ja kolmen pohjoissuomalaisen ala-alueen osalta taulukoissa 14 ja 19, yhteenvedon tapaan myös s. $338-339$. 
Kun uudisraivausten taloudellinen edullisuus vaihtelee tilakohtaisesti, on vastaavia tuloslukuja pyritty selvittämään myöskin marginaalilaskelmilla, joissa on arvioitu viljelmän peltoalan yhden hehtaarin, sekä myöskin sijoitetun pääoma- ja työyksikön lisäyksen vaikutus (Luku V). Kuten luvussa VII on esitetty, lineaariseen ohjelmointiin perustuva laskutapa on teoreettisesti parempi, mutta sen soveltaminen on jäänyt toisessa yhteydessä suoritettavaksi.

Uudisraivausten edullisuutta arvioitaessa joudutaan kiinnittämään huomiota myös raivausten kustannuksiin ja niiden rahoitukseen. Edelleen joudutaan ottamaan huomioon myös menetettävän metsäntuotoksen arvo. Sitä arvioitaessa osoittautuu tärkeäksi mm. niiden puustojen kypsyysaste, jotka joutuvat raivauksen kohteeksi (Luku VI). Tulon menetyksen arvioinnissa on sovellettu kolmea vaihtoehtoista menettelyä, joista yksi tähtää odotusarvon koron (interest on expectation value), toinen kiertoajan jäljellä olevana jaksona saatavan vuotuistulon (annuity) ja kolmas seuraavana 10-vuotiskautena tapahtuvan arvokasvun (value growth) määrittämiseen. Kun puuston markkina-arvon korko (3\% mukaan) on vähennystekijänä otettava huomioon, menetys vaihtelee kiertoajan eri vaiheissa jopa moninkertaisesti (vrt. taul. 21). Laskelmien epävarma kohta on tietenkin tuleva hintakehitys, jota on vaikea arvioida. Taulukossa 22 s. 351 on vastaavia arviolukuja esitetty olettaen, että puun kantohinnat yleiseen hintatasoon verrattuina kohoaisivat kymmenvuotiskausittain 5 prosentilla.

Uudisraivausten merkitystä joudutaan arvostelemaan myöskin kansantaloudelliselta kannalta. Vertailu perustuu tällöin nettokansantuotteeseen (NNP), joka saavutetaan kummankin tuotannon kautta. Tällaisissa laskelmissa on otettu huomioon myös alkutuotantoon perustuva toisen asteen tuotanto (kuljetukset, teollinen jalostus). Hinnoittelussa on maailmanmarkkinoilla liikkuvien tuotteiden osalta käytetty hintoja, joiden on arvioitu muodostuvan, jos tärkeimmät kulutusmaat siirtyisivăt vapaan kaupan kannalle. Näillä perusteilla lasketut nettokansantuotteen arvot hehtaaria kohden tutkimusalueittain on yhteenvedon tapaan esitetty taulukoissa 23 ja 24 sekä sivulla 360 .

Tähän tutkimukseen liittyviä tuloksia on aikaisemmin suomeksi esitetty julkaisuissa Lasola (1965), Maatalouskomitean mietintö (kom. miet. 1962: 6 Liite VIII, 161-180), sekä Pтнкala \& Lasola (1973). 


\section{Appendix I}

\section{Price structures relevant to this study}

The economic calculations of this study are based as a rule on the average nominal prices prevailing in the period 1959-63 (or assuming an alternative where to the prices of forest products an approximate 5 per cent increase per decade has been added). The price trends and fluctuations of agricultural and forest products before and during the study period are discussed in detail in an earlier study (PIнкац 1965, pp. 7-19). At the time of finishing the manuscript, price data of five years following the study period are available; these facilitate the levelling of cyclical variations especially characteristic of lumber prices, but do not give a reliable basis for long-term predictions. We do not venture on predictions in this connection, especially as the existing international forecasts only refer to the consumption assuming no changes in the relationship between the prices of wood and nearest substitutes (Wood: World Trends and Prospects. EAO, Rome 1967, p. 2.).

The recent trends are visible in Figures 1 and 2. These, as well as other changes, are based on deflated prices, i.e. nominal prices divided by the index of wholesale prices (general index for home market goods).

Political factors greatly influence the development of agricultural prices and rural wages; the latter, for their part, influence the stumpage prices. The inflationary tendencies which seem inevitably to be connected with post-war economic development, further aggravate the difficulties of price prediction.

The prices of agricultural products were under the period of study regulated by the Law on Farm Price Level of 1958, in which fixed prices were guaranteed for wheat and rye and target prices for milk, pork and eggs, to ensure to the farmers a stabilized income in relation to the cost items, including the wages of agricultural labourers. This law was to some extent revised in 1962. There were complementary decrees, regarding some other products; various subsidies were stipulated among others on a regional basis. For example, the milk prices were subsidized in Northern Finland and some other regions, and special subsidies were paid according to the number of milk cows.

There was some surplus production in agriculture which had to be exported on export subsidies. Thus 18200 to butter, 17200 to cheese and 4000 to milk powder was exported in 1959 -63 , corresponding to the processed produce of 16 per cent of the total milk production. The export prices were only about 40 per cent of the domestic wholesale prices. - For the calculaation of the advantage to national economy, milk prices are reduced to an extent which is sufficient to pay the export premiums of the total gross value of the milk production.

The five year average prices of agricultural products relevant to this study are collected into Table 2, where the regional averages of producer prices are taken for most products from the statistics of the Marketing Research Institute of the Pellervo-Society. ${ }^{1}$ ) The milk prices

1) The statistics are based on the prices paid by a sample of farmer cooperatives, weighed monthly by bought quantities. The regional division (South Finland, Central Finland and Ostrobothnia) corresponds only approximately to the division of this study. Only national averages are published (Pellervon Kalenteri). 
are actual prices received by the owners of study farms. They include the subsidies paid direct to the farmers. The subsidies paid according to the number of cows are mentioned separately, estimated as averages of study farms, differing in relation to the possibilities of sharing these subsidies. The prices of sugar beets are reported by factories and refer to prices paid on the farm.

Although the relative increase in the price index of agricultural products after the period of study is small, there is more evidence of a future drop in the domestic prices of these products than of their rise or remaining at the present level. If the efforts aiming at economic integration succeed, the latter alternatives are presumably excluded.

The prices of forestry products (see Table 1) have not been influenced by Government intervention except for a short period after 1957 when export levies were collected. As may be seen from Figure 1, teh fluctuations in stumpage prices have been large, while the increasep capacity of the wood-working industries has increased the demand of pine pulp wood, which especially in North Finland has greatly risen in value. This rise seems so convincing that it may justify correspondingly increased prices, reduced however by the depreciation of currency, as an alternative in this region.

The wages of forest workers, as estimated by the statistics of the State Forestry Board, have shown a steady rise ever since the War, and the index of real wages, e.g. of lumber jacks with hourly wages shows an upward trend of 4.7 per cent per year. Eventually this trend may check the rise of stumpage prices, and even bring about a falling tendency. To the farm forest owners, performing the logging operations with family labour, this development is practically irrelevant.

Table 1. The stumpage prices of forestry products, used in this study $(1959-63)$, by study areas, mk per cu. m. (s), without bark.

\begin{tabular}{|c|c|c|c|c|c|c|c|}
\hline & SF & W & MF & Ssm & & $\mathrm{Ku}+\mathrm{Sa}$ & \\
\hline Saw logs $\ldots \ldots \ldots \ldots \ldots \ldots$ & 31.44 & 33.26 & 27.28 & 21.44 & & 20.46 & \\
\hline Spruce pulp wood ....... & 20.43 & 21.72 & 16.24 & 11.21 & & 8.50 & \\
\hline Pine pulp wood .......... & 13.55 & 14.11 & 10.79 & 3.86 & $(8.48)$ & 2.07 & (5.19) \\
\hline Birch fuel wood ......... & 6.90 & 7.42 & 3.06 & 1.50 & & 0.24 & \\
\hline Weighed av. .......... & 21.90 & 20.68 & 15.35 & 11.45 & & 9.90 & \\
\hline
\end{tabular}

There have been large differences in the stumpage prices of wood for different uses. Thus the average prices per cu. m. (s) of coniferous logs, spruce and pine pulp, and fuel wood of birch have been respectively $28: 87,17: 49,10: 74$ and $4: 56$ in the period 1959-63. The average price of the wood material increases with the age of the timber stand, with a larger saw log ratio in the older stands. This increase is accentuated by the fact that the logs in larger diameter classes are valued higher per volume unit. There is no overall information about the value relations, so that certain figures presented by RoNKANEN (Footnote ${ }^{1}$ ) and HARve (Footnote ${ }^{2}$ ) are used here with some modifications. The farmer refer to cubic foot price ratios for saw logs of various top diameters, conveyed to saw mills, the latter are relative values of whole trees with a varying technical cubic foot output. For our calculations, the different logging costs for logs of varying sizes, as well as the costs of water or road transport are deducted from the saw mill prices to obtain the stumpage value and their relations in the first alternative. In most calculations the latter ratios are applied, as the available data do not allow cutting into length computations. The relative figures involved are as follows:

1) Tapion Taskukirja 1966, p. 393 (Heiskanen).

$\left.{ }^{2}\right)$ ref. Kallio 1957, p. $90-93$. 


\begin{tabular}{|c|c|c|c|c|c|c|c|c|}
\hline Top measure of $\log$ & $5^{\prime \prime}$ & $6 "$ & $7^{\prime \prime}$ & $8^{\prime \prime}$ & $9^{\prime \prime}$ & $10^{\prime \prime}$ & $11^{\prime \prime}$ & $12^{\prime \prime}$ \\
\hline 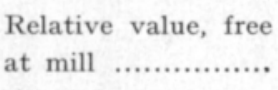 & 74 & 89 & 96 & 100 & 104 & 111 & 122 & 126 \\
\hline $\begin{array}{l}\text { Relative value, } \\
\text { stumpage } . . . \ldots \ldots \ldots . . . .\end{array}$ & 54 & 80 & 92 & 100 & 107 & 119 & 137 & 144 \\
\hline $\begin{array}{l}\text { Estimated volume } \\
\text { of tree, cu. ft. ..... }\end{array}$ & $7-7.9$ & $8-8.9$ & $9-9.9$ & $10-10.9$ & $11-11.9$ & $12-12.9$ & $13-13.9$ & $14-14.9$ \\
\hline $\begin{array}{l}\text { Relative stumpage } \\
\text { value of one cu. } \mathrm{ft} . \\
\text { sawn timber ........... }\end{array}$ & 91 & 94 & 97 & 100 & 103 & 106 & 109 & 111 \\
\hline
\end{tabular}

The costs of logging decrease with an increasing diameter of the trees. An estimate in the conditions of NE area, applying rates of agreement on terms of work for the year 1961, gives the following time and cost figures: ${ }^{1}$ )

\begin{tabular}{|c|c|c|c|c|c|c|c|c|}
\hline Top measure & $5 "$ & $6^{\prime \prime}$ & $7^{\prime \prime}$ & $8^{\prime \prime}$ & $9^{\prime \prime}$ & $10^{\prime \prime}$ & $11^{\prime \prime}$ & $12^{\prime \prime}$ \\
\hline Saw logs, m. hrs. .... & 0.133 & 0.126 & 0.120 & 0.115 & 0.112 & 0.109 & 0.107 & 0.105 \\
\hline h. hrs. ...... & 0.037 & 0.035 & 0.034 & 0.033 & 0.033 & 0.032 & 0.032 & 0.031 \\
\hline Mk per cu. ft. .......... & $-: 33.5$ & $-: 31.7$ & $-: 30.4$ & $-: 29.2$ & $-: 28.5$ & $-: 27.9$ & $-: 27.4$ & $-: 26.8$ \\
\hline Ratio $\left(8^{\prime \prime}=100\right) \ldots \ldots$ & 115 & 109 & 104 & 100 & 98 & 96 & 94 & 92 \\
\hline & & & pine & & & & spruce & \\
\hline Top measure & & $3^{\prime \prime}$ & $4^{\prime \prime}$ & $5^{\prime \prime}$ & & $3 "$ & $4^{\prime \prime}$ & $5^{\prime \prime}$ \\
\hline Piled wood, m. hrs. & ...... & 8.99 & 4.89 & 3.35 & & 9.60 & 5.24 & 3.81 \\
\hline h. hrs. .... & n......... & 0.63 & 0.63 & 0.63 & & 0.63 & 0.63 & 0.63 \\
\hline per $\mathrm{cu} / \mathrm{m}$ & n........ & $18: 83$ & $10: 83$ & $7: 83$ & & $20: 03$ & $11: 53$ & $8: 83$ \\
\hline Ratio $\left(5^{\prime \prime}=100\right)$ & ... & 240 & 138 & 100 & & 227 & 131 & 100 \\
\hline
\end{tabular}

As unequal logging costs are taken into account in stumpage price calculations, the logging costs, being also an income item to the farmers, are as a rule assumed to be constant. The time figures are, however, differentiated to some extent. Thus, so-called thin pulp wood, with a top diameter of $2^{\prime \prime}$, is estimated to require double work time as compared to $3^{\prime \prime}$ material so that the yields are very low (ca. 20 per cent of the normal, i.e. $5^{\prime \prime}$ top measure) for the thinning enthusiast owners ${ }^{2}$ ).

$\begin{array}{lccc} & \% & \text { Aver. } \\ \text { Deposit rate of savings banks ........... } & 4.18-6.06 & 4.67 \\ \text { Loan rate of commercial banks .......... } & 6.90-7.95 & 7.32 \\ \text { Discount rate of Bank of Finland ...... } & 63 / 4-7.00 & -\end{array}$

The depreciation of the mark, measured by the change in wholesale price indexes, has varied between -1.0 and +9.5 per cent per year. The average depreciation has been 3.9 per sent per year.

Note to complement the data on agriculture:

Prices of fertilizers and lime, based on statistics published by the Pellervo-Society, per kg pure plant nutrients:

1) For the more detailed explanations, see P1нкala \& Lasola 1973, p. $419 \mathrm{ff}$.

2) The computations of Petterson (1963, p. 296 ff) in Sweden show that thinning operations yield a net return, if administration costs are not taken into account, from $60-80$ years onwards. 
Nitrogen $(\mathrm{N})$, nitrate of lime ...................... 1:03

nitrate of $\mathrm{Ca}$ and $\mathrm{NH}_{4} \ldots \ldots \ldots \ldots \ldots \ldots \ldots . . . \cdots \ldots 1$

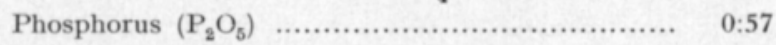

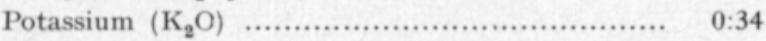

Lime $(35 \% \mathrm{CaO})$ 20:56 per to ..................... 0:06

The price of oil cakes has been estimated at an average of 0:55 per fodder unit.

The cow subsidies, paid in certain zones in the Northern half of the country, per cow are:

$\begin{array}{lcc}\text { MF varying in different zones, } & 0 & (3 \text { subareas }) \\ & 13:-(2-,-) \\ & 24:-(5-,-) \\ \text { NE all subareas } & 46:-(7-,-)\end{array}$

Table 2. Prices applied in the economic calculations. Average producer prices in the period 195963 , by main areas and three North Eastern subareas, mk per kg.

\begin{tabular}{|c|c|c|c|c|c|c|c|c|}
\hline & SF & W & MF & NE & Ssm & Ku & $\mathrm{Sa}$ & $\begin{array}{l}\text { Country } \\
\text { average }\end{array}$ \\
\hline Wheat ........................ & $-: 46.9$ & $-: 47.1$ & $(-: 47.7)$ & - & - & - & - & $-: 47.4$ \\
\hline 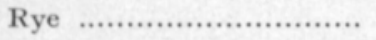 & $-: 47.1$ & $-: 51.5$ & $-: 52.4$ & - & $-: 52$ & - & - & $-: 49.8$ \\
\hline Barley (feed) ............... & $-: 28.3$ & $-: 33.2$ & $-: 27.8$ & $-: 28.7$ & . & . & . & $-: 28.2$ \\
\hline Oats (feed) $\ldots . \ldots \ldots \ldots \ldots . . . . . . . .$. & $-: 30.1$ & $-: 27.6$ & $-: 29.6$ & $\cdot$ & . & . & . & $-: 27.1$ \\
\hline Potatoes ....................... & $-: 11.1$ & $-: 11.1$ & $-: 11.5$ & $-: 09.5$ & . & . & . & $-: 12.3$ \\
\hline Sugar beets .................... & $-: 09.7$ & $-: 09.7$ & - & - & . & . & . & $-: 09.7$ \\
\hline 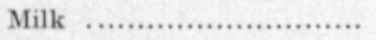 & $-: 33.5$ & $-: 33.4$ & $-: 33.8$ & $-: 38.1$ & $-: 36.4$ & $-: 39.7$ & $-: 38.2$ & $-: 31.3$ \\
\hline Butter (exp. pr.) .............. & - & - & - & - & - & - & - & $2: 56$ \\
\hline Skim milk .................... & $-: 04.7$ & $-: 04.7$ & $-: 04.1$ & $-: 04.2$ & . & . & . & $-: 04$ \\
\hline 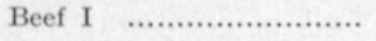 & $2: 98$ & $2: 98$ & $2: 82$ & $2: 93$ & . & . & . & $2: 84$ \\
\hline II $\ldots \ldots \ldots \ldots \ldots \ldots \ldots \ldots \ldots$ & $2: 68.6$ & $2: 68.6$ & $2: 48.8$ & $2: 59.6$ & . & . & . & $2: 52$ \\
\hline $\begin{array}{l}\text { Coniferous saw timber } \\
\text { per cu/f ....................... } \\
\text { Spruce pulpwood, per }\end{array}$ & $1: 22$ & $1: 28$ & 1:05 & $-: 81$ & $-: 84$ & $-: 80$ & $-: 80$ & $1: 12.6$ \\
\hline $\begin{array}{l}\text { pilde } \mathrm{cu} / \mathrm{m} \\
\text { Pilde pine wood, per }\end{array}$ & $13: 90$ & $14: 50$ & $10: 90$ & $6: 40$ & $7: 65$ & $5: 80$ & $5: 80$ & 11:98 \\
\hline $\begin{array}{l}\text { piled } \mathrm{cu} / \mathrm{m} \\
\text { Birch firewood, per piled }\end{array}$ & 9:05 & $9: 10$ & $6: 95$ & $1: 75$ & $2: 55$ & $1: 36$ & $1: 36$ & 7:05 \\
\hline $\mathrm{cu} / \mathrm{m}$......................... & $3: 50$ & $3: 80$ & $1: 55$ & $-: 38$ & $-: 85$ & $-: 15$ & $-: 15$ & $2: 43$ \\
\hline Horse day ..................... & $16: 80$ & $16: 80$ & 17:00 & $20: 90$ & $20: 40$ & $20: 40$ & 21:90 & $17: 96$ \\
\hline
\end{tabular}

The producer prices of marketable crop products are averages for the period 1959-63 within regions covering the study areas. The figures of the Market Research Institute of the Pellervo Society are used in most cases. The prices of sugar beets are prices on the farm.

The milk prices (except national average) include subsidies paid direct to farmers, but regional subsidies paid according to the number of cows are not included. There are regional subsidies also in some other prices, e.g. rye. 


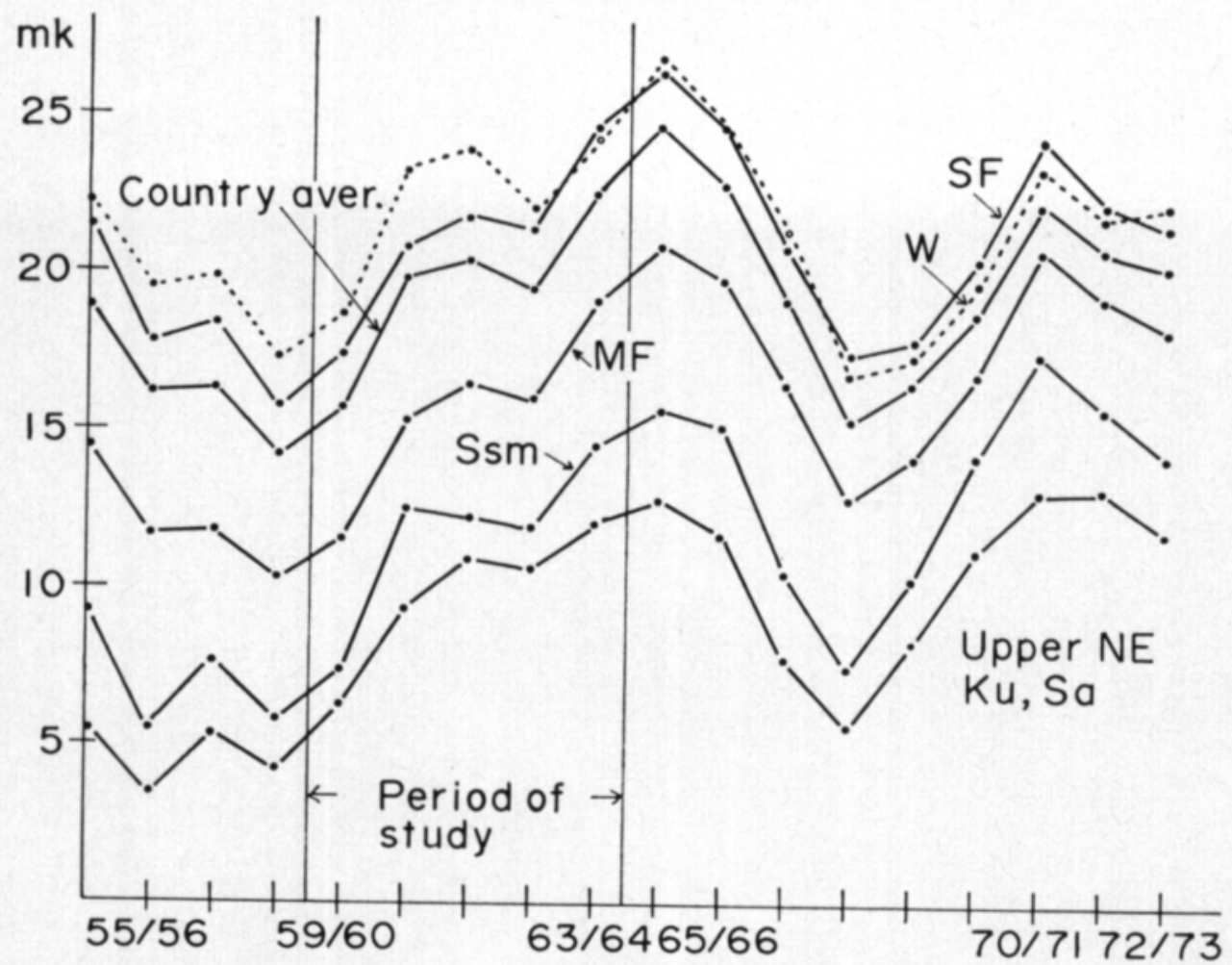

Fig. 2. The stumpage prices of timber disposed from private forests, mk per cu. m (s), without bark, by regions. The prices deflated by the wholesale price indexes to the 1963 mark value.

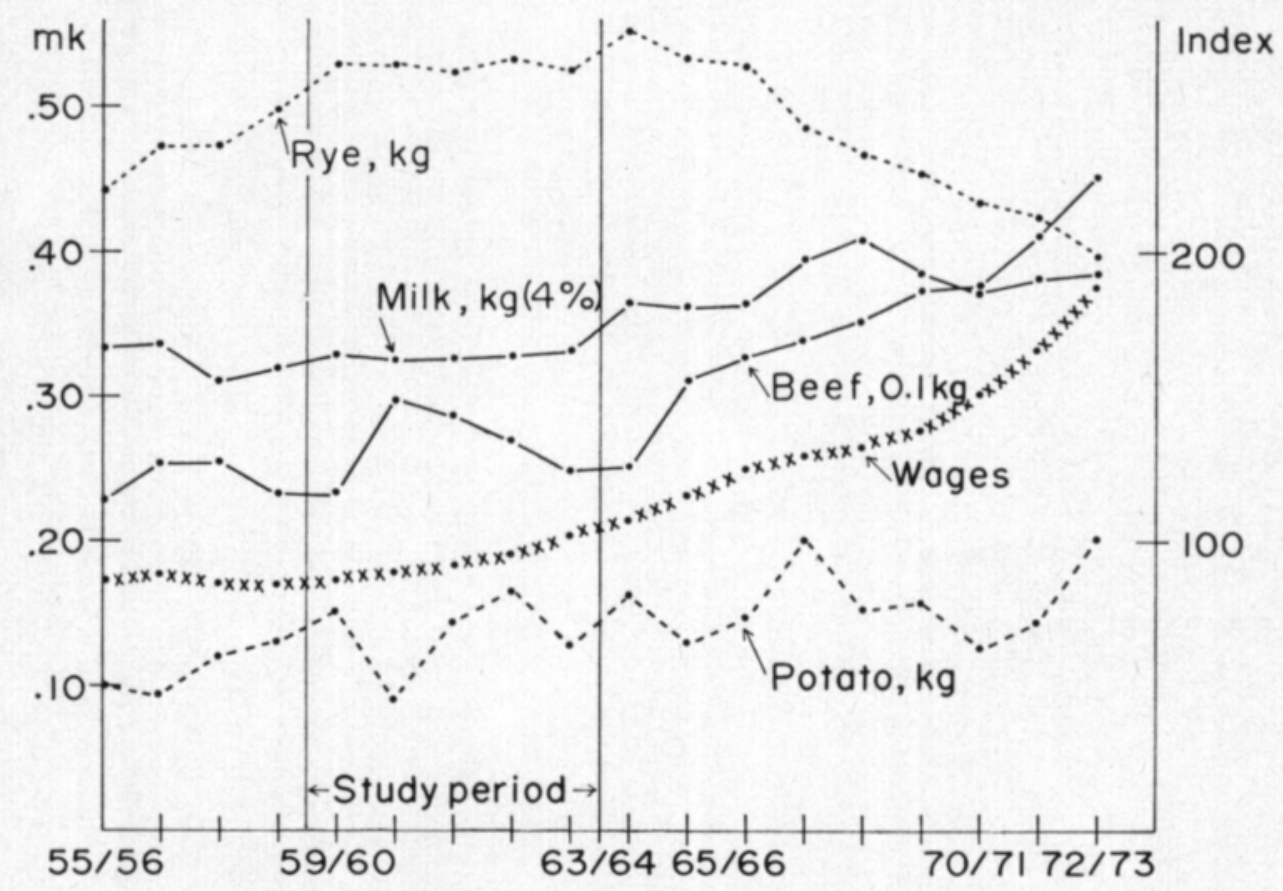

Fig. 3. The deflated prices of most relevant farm products and deflated indexes of farm wages. 
APPENDIX II.

Method of estimation of beef production

(1) Three economic alternatives for feeding beef calves

\begin{tabular}{|c|c|c|c|}
\hline & I & II & III \\
\hline 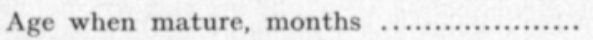 & 8 & 24 & 19 \\
\hline 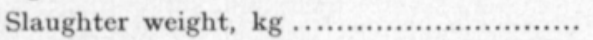 & 110 & 235 & 167 \\
\hline Whole milk, kg ................ & 62 & 62 & 100 \\
\hline 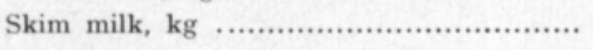 & 950 & 680 & 1521 \\
\hline 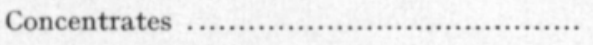 & 240 & 120 & 30 \\
\hline 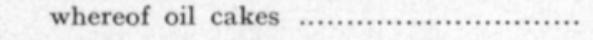 & 80 & - & - \\
\hline AIV-silage f.u. ................................... & - & 250 & 152 \\
\hline , $\quad$...................................... & 100 & 704 & 498 \\
\hline 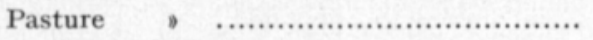 & 240 & 1180 & 778 \\
\hline Total fodder units ............................. & 701 & 2345 & 1622 \\
\hline Kg skim milk, per kg slaughter weight & 8.65 & 2.89 & 9.11 \\
\hline F.u. non-marketable feed & 3.09 & 9.08 & 8.55 \\
\hline concentrates & 2.18 & 0.511 & 0.180 \\
\hline Total feed & 6.37 & 9.978 & 9.772 \\
\hline
\end{tabular}

(2) Beef production, estimated on the basis of the number of calf births and available skim milk

\begin{tabular}{|c|c|c|c|c|c|c|c|c|}
\hline & & SF & W & MF & NE & Ssm & Ku & $\mathrm{Sa}$ \\
\hline Calf bir & ths per hectare $\mathrm{n}$ & 0.376 & 0.386 & 0.368 & 0.480 & 0.448 & 0.712 & 0.448 \\
\hline $\begin{array}{l}\text { Skim n } \\
\text { Skim r } \\
\text { kg }\end{array}$ & $\begin{array}{l}\text { ilk available kg } \\
\text { nilk requirement }\end{array}$ & 1116 & 847 & 715 & 973 & 1085 & 1209 & 484 \\
\hline I & ............ & 356 & 367 & 350 & 456 & 426 & 676 & 426 \\
\hline II & …….............. & 256 & 262 & 250 & 326 & 305 & 484 & 305 \\
\hline III & 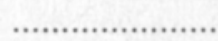 & 572 & 587 & 559 & 729 & 681 & 1082 & 681 \\
\hline
\end{tabular}

Maximum beef prod.

per ha, kg

\begin{tabular}{|c|c|c|c|c|c|c|}
\hline …………...... & 129.0 & 97.9 & 82.7 & 112.5 & 125.4 & 139.8 \\
\hline II $\ldots \ldots \ldots \ldots \ldots \ldots \ldots$ & 386.2 & 293.1 & 247.4 & 337.7 & 375.4 & 383.7 \\
\hline
\end{tabular}

(3) Beef production, estimated on the basis of non-marketable (roughage) fodder.

\begin{tabular}{|c|c|c|c|c|c|c|c|c|}
\hline & & SF & w & MF & NE & Ssm & $\mathrm{Ku}$ & Sa \\
\hline $\begin{array}{l}\text { Non-mar } \\
\text { available } \\
\text { requirem } \\
\text { calves fe }\end{array}$ & $\begin{array}{l}\text { ketable fodder, } \\
\text { ent, if all } \\
\text { d }\end{array}$ & 299 & 143 & 242 & 593 & 572 & 96 & 85 \\
\hline alt. I & ............. b & 128 & 131 & 125 & 163 & 152 & 242 & 152 \\
\hline II & ............... c & 802 & 819 & 785 & 1024 & 956 & 1519 & 956 \\
\hline III & $\ldots \ldots \ldots \ldots \ldots, d$ & 537 & 551 & 551 & 685 & 640 & 1016 & 640 \\
\hline
\end{tabular}


Optimum use ${ }^{1}$ )

\begin{tabular}{|c|c|c|}
\hline & ..........e e & 127 \\
\hline HI & $\begin{array}{ll}\ldots & f 227\end{array}$ & 16 \\
\hline
\end{tabular}

Production on beef

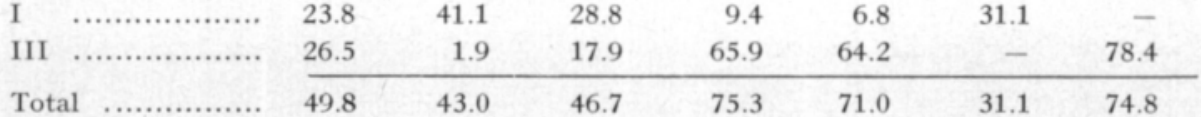

Requirement of

$\begin{array}{crrrrrrr}\text { whole milk .......... } & 29 & 24 & 27 & 44 & 42 & 18 & 48 \\ \text { skim milk ........... } & 443 & 373 & 412 & 681 & 645 & 269 & 484) \\ \text { concentrates ......... } & 54 & 90 & 65 & 28 & 26 & 68 & 41 \\ \text { on-utilized skim milk } & 673 & 474 & 303 & 292 & 440 & 940 & 404\end{array}$

\section{APPENDIX III.}

Estimate on the fodder saving per hectare of total cultivated area, caused by more efiective use of horses, when moving from the actual average size of farms to size class II, which is assumed to be 15 ha in all study areas.

(a) Total feed use and feed cost per farm (cf. Tables 9 and 10 pp. 319, 320.)

Actual farm size:

Marketable feed, f.u.

Non-marketable feed,

f.u.

Value, $\mathrm{mk}$................ 378.81

Size class II (15 ha cultivated area, number of horses according to P. I.):

Marketable feed, f.u.

f.u.

Value, mk

298

307

307

260

260

260

260

Subareas

$\mathrm{Ku} \quad \mathrm{Sa}$

$105 \quad 181$

$\begin{array}{ll}661 & 1142\end{array}$

$166.85 \quad 288.13$

1944

1643

$1643 \quad 1643$

1643

475.14

490.11

490.11

414.40

414.40

414.40

414.40

(b) Value of feed, mk per ha

Actual farm size $\quad 42.32$

Size class II ............. 31.67

52.79

Savings, mk/ha .......... 10.65

32.67

43.81

39.04

32.72

54.35

41.94

32.67

27.62

27.62

27.62

Feed requirement per adult horse: grain 317 f.u., non-marketable fodder 2004 f.u.

\section{APPENDIX IV.}

The saving in costs of building capital per ha obtained by increase of cultivated area, assuming a) that no additional building space is needed, b) the building capital of I size class farms is stepwise substituted by respective capital of II size class, c) that larger building volume is necessary (type 1. barn).

1) Optimum use is calculated aiming at the sum which corresponds to the available quantity of non-marketable fodder. To obtain the values on the rows e and $f$, the equation by $+d(1-$ $\mathbf{x})=\mathrm{a}$ is solved in regard to $\mathbf{x}$, and the values on rows $\mathrm{e}$ and $\mathrm{f}$ are obtained multiplying the per animal use of non-marketable feed by product $\mathrm{nx}$ for values of row e and by $\mathrm{n}$. $(1-\mathrm{x})$ for row $\mathrm{f}(\mathrm{n}=$ number of calf births per ha). The values of alt. II (row c) are not relevant in this connection. 
(1) Estimate based on Profitability Investigation (cf. Table 14, p. 71)

a) cost items after 1 ha extension

\begin{tabular}{|c|c|c|c|}
\hline & SF & $\mathbf{W}+\mathbf{M F}$ & NE \\
\hline Deprec. \& rep. ............... & 42.43 & 40.17 & 40.34 \\
\hline $\begin{array}{l}\text { Inrerest }(3 \%) \\
\text { saving per hectare caused by one hectare inc }\end{array}$ & $\begin{array}{l}38.63 \\
\text { sse }\end{array}$ & 39.85 & 42.35 \\
\hline Deprec. \& rep. ..................................... & 5.63 & 5.30 & 5.75 \\
\hline (......................................... & 5.12 & 5.26 & 6.03 \\
\hline
\end{tabular}

b) differences between size classes I and II (see Table 14, p. 71)

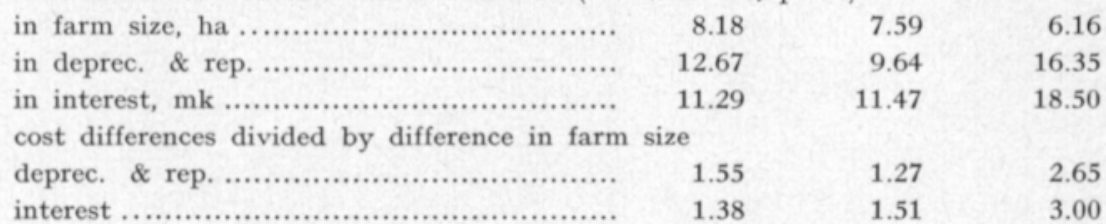

(2) Estimate based on actual farm size of study farms and cost figures of Land Settlement Investigation Committee

a) cost items after 1 ha extension

$\begin{array}{lccccccc} & \text { SF } & \text { W } & \text { MF } & \text { NE } & \text { Ssm } & \text { Ku } & \text { Sa } \\ \text { Deprec. \& rep. } & 52.09 & 72.40 & 58.85 & 79.04 & 58.39 & 127.40 & 65.87 \\ \text { Interest ........ } & 19.53 & 27.27 & 21.97 & 29.64 & 21.82 & 47.77 & 24.70 \\ \text { saving per hectare caused } & \text { by one hectare increase } & & & \\ \text { Deprec. \& rep. } & 5.83 & 11.82 & 7.20 & 14.22 & 7.10 & 41.50 & 9.50 \\ \text { Interest ........ } & 2.19 & 4.45 & 2.80 & 5.34 & 2.19 & 15.56 & 3.60\end{array}$

c) differences between actual per hectare costs and costs if type 1. building is fully utilized (15 ha farm size)

$\begin{array}{lrrrrrrr}\text { Deprec. \& rep. } & -4.32 & 25.92 & 5.24 & 37.21 & 4.94 & 126.07 & 16.30 \\ \text { Interest } \ldots \ldots \ldots . & -1.87 & 8.08 & 1.67 & 11.85 & 1.58 & 40.24 & 5.20\end{array}$

(3) A calculatory example of the saving of cost of building capital per hectare when cultivated area is increased by one hectare in the Kuusamo subarea, where the cultivated area per farm was during the study period in aver. 3.07 ha. Note the effect of moving to type 1.

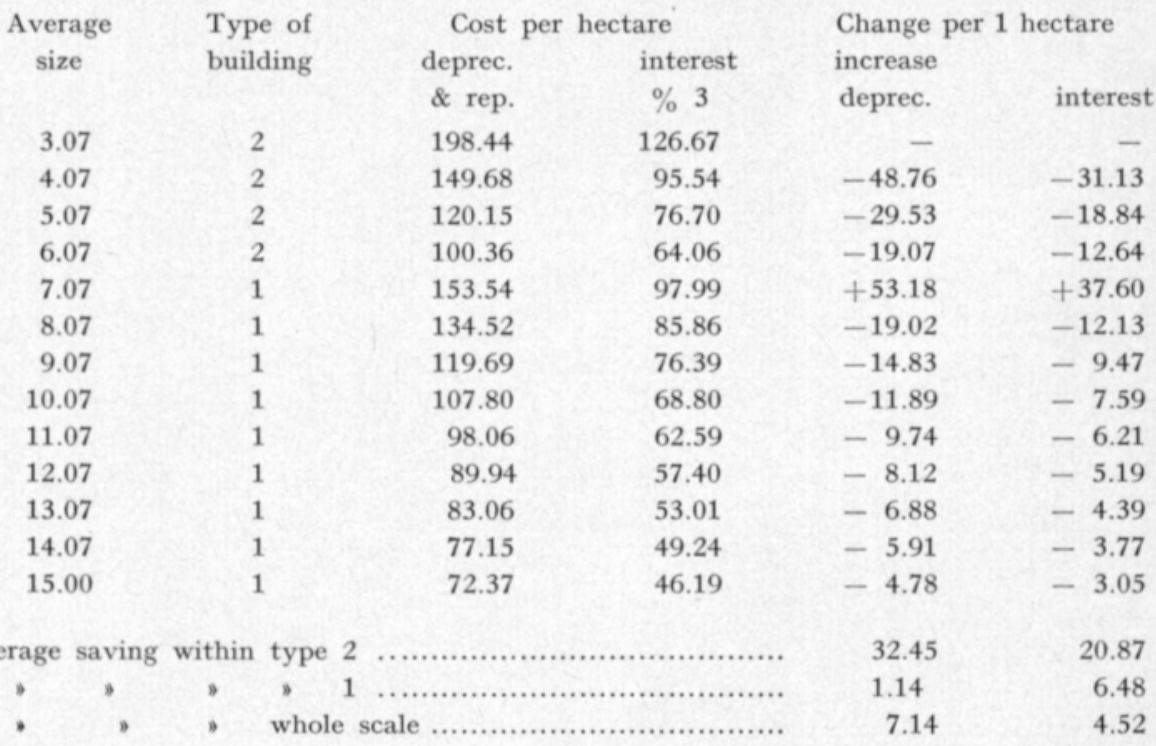


APPENDIX V.

Standards applied in labour time estimations, and some averages of earlier date, man hours.

$\begin{array}{cccccc}\text { Westermarck } & \text { Hjelm } & \text { Danish. stand. } & \text { This } & \text { Sipilä } & \text { Sandvist } \\ \text { \& Melén } & 7.5 \text { ha } & \begin{array}{c}\text { horse tractor } \\ \text { study }\end{array} & 1949^{1} \text { ) } & \\ \text { under 10 ha } & & \text { driven driven } & & \end{array}$

Autumn crops of

\begin{tabular}{|c|c|c|c|c|c|c|c|}
\hline grain ............... & 180 & 59 & 124 & 35 & 180 & 180 & - \\
\hline Spring grain ........ & 150 & 56 & 110 & 34 & 150 & 150 & - \\
\hline Potato ................. & 580 & 225 & 379 & 306 & 580 & 580 & - \\
\hline Sugar beet ........... & 700 & 264 & 349 & 259 & 700 & 700 & - \\
\hline Other root crops .. & 650 & - & - & - & 650 & 650 & - \\
\hline Hay .................... & 90 & 56 & 61 & 48 & 90 & 90 & - \\
\hline Pasture ................ & 30 & - & 15 & 7 & 30 & - & - \\
\hline $\begin{array}{l}\text { Adult horse .......... } \\
\text { Young cattle }\end{array}$ & 150 & 一 & 125 & - & 150 & - & - \\
\hline$(24 \mathrm{~m}.) \quad \ldots \ldots \ldots \ldots \ldots . . . . .$. & 130 & $40-48$ & - & - & 130 & - & - \\
\hline Milk cow ................ & 220 & - & - & - & - & - & - \\
\hline herd size 3 & - & - & 305 & - & 345 & 450 & - \\
\hline$\Rightarrow 4$ & - & 一 & 245 & - & 295 & 415 & 240 \\
\hline,$\quad 5$ & - & - & 208 & - & 260 & 396 & - \\
\hline$\cdot \quad 7$ & - & 116 & $\cdots$ & - & 210 & - & - \\
\hline,$\quad 8$ & - & - & 153 & 一 & 195 & 310 & 185 \\
\hline,$\quad 10$ & - & 105 & 135 & - & 180 & 290 & - \\
\hline,$\quad 12$ & - & - & 123 & - & 168 & 285 & 150 \\
\hline$, \quad, 15$ & - & 95 & 111 & - & 160 & 280 & - \\
\hline Pig $100 \mathrm{~kg} . . . . . . . .$. & 15 & - & - & - & - & - & - \\
\hline 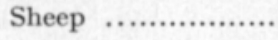 & 8 & - & - & - & - & - & - \\
\hline
\end{tabular}

\section{APPENDIX VI.}

Forest production figures, by site types. ${ }^{2}$ )

\begin{tabular}{|c|c|c|c|c|c|c|c|c|c|c|c|c|c|c|}
\hline 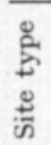 & 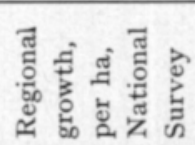 & 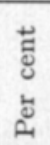 & 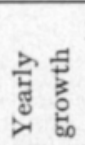 & 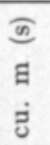 & 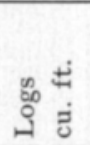 & 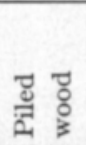 & $\begin{array}{l}\text { ఏ } \\
\text { घ } \\
\text { ปें }\end{array}$ & 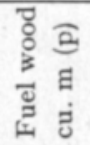 & 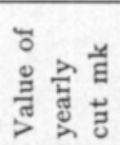 & हू & 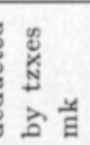 & 胥 & S & 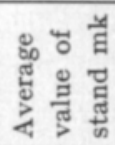 \\
\hline
\end{tabular}

South Finlands main area

\begin{tabular}{|c|c|c|c|c|c|c|c|c|c|c|}
\hline OMT $\ldots \ldots \ldots \ldots \ldots$ & 4.9 & 17.8 & 6.59 & 72.7 & 4.09 & 1.57 & 138.8 & 132.0 & 80 & 2048.1 \\
\hline MT .................. & 4.4 & 38.7 & 5.26 & 58.2 & 3.33 & 0.95 & 109.2 & 103.4 & 90 & 1785.3 \\
\hline VT ............ & 3.5 & 16.8 & 4.80 & 46.7 & 2.67 & 1.55 & 81.3 & 77.0 & 90 & 1418.0 \\
\hline CT ................... & 2.1 & 3.6 & 2.69 & 2.08 & 1.53 & 1.06 & 38.8 & 35.4 & 120 & 763.9 \\
\hline K1 .................. & 3.4 & 11.5 & $(4.80)$ & $(46.7)$ & $(2.67)$ & (1.55) & (81.3) & $(77.0)$ & - & 1418.0 \\
\hline R1 .................. & 2.35 & 0.3 & (2.69) & $(20.8)$ & (1.53) & (1.06) & $(38.8)$ & $(35.4)$ & - & 763.9 \\
\hline Ojik.-Drained peat & 4.15 & 11.3 & $(4.79)$ & 36.5 & 3.00 & 1.55 & 81.3 & 77.0 & - & 1418.0 \\
\hline & .92 & 00.0 & 5.21 & 53.6 & 3.17 & 1.30 & 100.7 & 95.38 & - & 1646.8 \\
\hline
\end{tabular}

Western main area

\begin{tabular}{|c|c|c|c|c|c|c|c|c|c|c|}
\hline OMT ........... & 4.7 & 3.1 & 5.93 & 65.4 & 3.68 & 1.41 & 124.9 & 118.8 & 80 & 1843.3 \\
\hline MT $\ldots \ldots \ldots \ldots \ldots \ldots$ & 4.0 & 9.1 & 4.73 & 52.4 & 3.00 & 0.86 & 98.3 & 93.1 & 90 & 1606.8 \\
\hline VT ................... & 2.8 & 38.0 & 4.32 & 42.0 & 2.40 & 1.40 & 73.2 & 69.3 & 90 & 1276.2 \\
\hline CT ..... & 1.8 & 34.0 & 2.42 & 18.7 & 1.38 & 0.95 & 34.9 & 31.9 & 120 & 687.5 \\
\hline K1 $\ldots \ldots \ldots \ldots \ldots \ldots$ & 2.9 & 7.6 & $(4.32)$ & $(42.0)$ & $(2.40)$ & $(1.40)$ & $(73.2)$ & (69.3) & - & 1276.2 \\
\hline R1 $\ldots \ldots \ldots \ldots \ldots \ldots$ & 1.7 & 8.2 & $(2.42)$ & (18.7) & (1.38) & $(0.95)$ & $(34.9)$ & (31.9) & - & 687.5 \\
\hline Ojik. ................ & 3.3 & - & $(4.32)$ & $(42.0)$ & $(2.40)$ & $(1.40)$ & (73.2) & (69.3) & - & 1276.2 \\
\hline & 2.55 & 100.0 & 3.61 & 33.8 & 2.06 & 1.16 & 60.9 & 57.22 & - & 1075.4 \\
\hline
\end{tabular}

1) Interpolated values

2) Growth figures are cu. m (s), without bark. 
Forest production figures, by site types. (Continued).

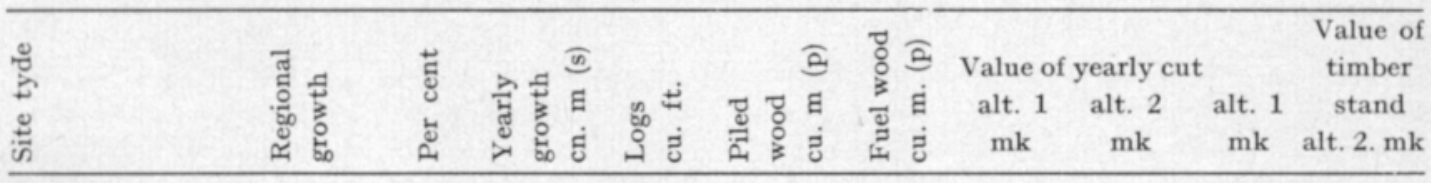

Middle Finland main area

\begin{tabular}{|c|c|c|c|c|c|c|c|c|c|c|}
\hline OMT $\ldots \ldots \ldots \ldots \ldots$ & 4.2 & 2.2 & 5.60 & 61.8 & 3.48 & 1.33 & 118.0 & 112.2 & 80 & 1740.9 \\
\hline MT $\ldots \ldots \ldots \ldots \ldots \ldots$ & 3.85 & 17.3 & 4.47 & 49.5 & 2.83 & 0.81 & 92.8 & 87.9 & 90 & 1517.5 \\
\hline VT $\ldots \ldots \ldots \ldots \ldots \ldots \ldots$ & 2.8 & 35.3 & 4.08 & 39.7 & 2.27 & 1.32 & 69.1 & 65.4 & 90 & 1205.3 \\
\hline CT ... & 2.4 & - & 2.29 & 17.7 & 1.30 & 0.90 & 33.0 & 30.1 & 120 & 649.3 \\
\hline K1 .................. & 2.3 & 18.0 & $(2.29)$ & (17.7) & $(1.30)$ & $(0.90)$ & $(33.0)$ & $(30.1)$ & - & 649.3 \\
\hline R1 .................. & 1.7 & 10.3 & $(0.68)$ & - & - & - & - & - & - & - \\
\hline \multirow[t]{2}{*}{ Ojik. ................... } & 2.5 & 16.9 & $(4.08)$ & 39.7 & 2.27 & 1.32 & 69.1 & 65.4 & - & 1205.3 \\
\hline & 2.75 & 100.0 & 3.54 & 34.4 & 2.03 & 1.01 & 62.1 & 58.6 & - & 1068.6 \\
\hline
\end{tabular}

\begin{tabular}{|c|c|c|c|c|c|c|c|c|c|c|}
\hline MT ....... & 2.3 & 10.3 & $(2.49)$ & 13.3 & 1.97 & 0.43 & 25.95 & $(25.95)$ & 1113 & (1113) \\
\hline EVT ................. & 2.2 & 52.5 & 3.53 & 49.0 & 1.33 & 0.31 & 47.73 & (51.89 & 1923 & (2041) \\
\hline ECT...$\ldots \ldots \ldots \ldots$ & 1.8 & 4.5 & 2.59 & 21.0 & 1.59 & 0.16 & 21.89 & $(26.82)$ & 580 & $(738$ \\
\hline $\left.\mathrm{K}^{1}{ }^{1}\right) \ldots \ldots \ldots \ldots \ldots \ldots$ & 1.5 & 7.2 & $(2.03)$ & (11.3) & (1.01) & (1.01) & (15.33) & (15.33) & ( 658) & $(658)$ \\
\hline R1 $\ldots . \cdots \cdots \cdots \cdots$ & 1.3 & 25.5 & - & - & $(0.94)$ & $(0.94)$ & $(3.09)$ & $(5.86)$ & ( 133) & $(252)$ \\
\hline & - & 100.0 & - & 28.9 & 1.29 & 0.53 & 30.61 & 33.72 & 1232 & 1331 \\
\hline
\end{tabular}

Upper NF (Ku)

\begin{tabular}{|c|c|c|c|c|c|c|c|c|c|c|}
\hline $\left.\mathrm{MT}^{2}\right) \ldots \ldots \ldots \ldots \ldots$ & - & 16.3 & $(1.87)$ & $10.0)$ & $(1.48)$ & $(0.32)$ & $(16.16)$ & $(16.16)$ & ( 687$)$ & ( 687$)$ \\
\hline EVT $\left.^{3}\right) \quad \ldots \ldots \ldots \ldots$ & 1.6 & 17.7 & $(3.60)$ & (39.9) & (1.35) & $(0.15)$ & $(37.07)$ & $(41.08)$ & (1368) & (1553) \\
\hline $\left.\mathrm{EMT}^{3}\right) \quad \ldots \ldots \ldots \ldots$ & 1.3 & 23.0 & $(2.06)$ & $(20.6)$ & (1.26) & $(0.76)$ & $(18.28)$ & $(20.88)$ & $(666)$ & $(800)$ \\
\hline CT, HMT .... & 0.9 & 7.1 & $(1.05)$ & $(8.2)$ & $(0.60)$ & $(0.24)$ & $(8.19)$ & $(8.19)$ & 534) & 534) \\
\hline K1 $\quad \ldots \ldots \ldots \ldots \ldots \ldots$ & 1.2 & 14.3 & $(1.53)$ & $(7.5)$ & $(1.09)$ & $(0.37)$ & $(6.79)$ & $(9.03)$ & 210) & (288) \\
\hline R1 ................. & 1.2 & 21.6 & - & - & $(0.71)$ & $(0.71)$ & $(1.07)$ & $(2.51)$ & ( 45) & ( 105$)$ \\
\hline & - & 100.0 & - & 51.1 & 1.12 & 0.48 & 14.51 & 16.43 & 585 & 675 \\
\hline
\end{tabular}

\begin{tabular}{|c|c|c|c|c|c|c|c|c|c|c|}
\hline $\left.\mathrm{MT}-\mathrm{VMT}^{4}\right) \ldots \ldots$. & 1.6 & 5.6 & $(1.45)$ & $(7.8)$ & (1.15) & $(0.25)$ & (12.58) & $(12.58)$ & ( 629) & ( 629) \\
\hline EVT ................. & 1.2 & 24.8 & 2.80 & 31.0 & 1.05 & 0.12 & 28.83 & (31.95) & 1064 & (1208) \\
\hline EMT ................ & 1.0 & 31.5 & 1.60 & 16.0 & 0.98 & 0.59 & 14.22 & (16.24) & 518 & $(622)$ \\
\hline HMT $\left.^{5}\right) \quad \ldots \ldots \ldots \ldots . . .$. & 0.7 & 25.3 & 0.82 & 6.4 & 0.47 & 0.19 & 6.37 & $(6.37)$ & 415 & 415) \\
\hline $\mathrm{K} 1 \quad(=\mathrm{ErClT}) \ldots$ & - & 7.4 & 1.19 & 5.8 & 0.85 & 0.29 & 5.28 & $(7.02)$ & 163 & 224) \\
\hline R1 ................. & 0.9 & 5.4 & $(0.90)$ & - & $(0.55)$ & $(0.55)$ & $(0.83)$ & $(1.95)$ & ( 35) & $(82)$ \\
\hline
\end{tabular}

1) Estimated to be $171.4 \%$ of the figures of type ErClT in Upper NF.

${ }^{2}$ ) Estimated to be $75 \%$ of the figures of Kainuu.

${ }^{3}$ ) Estimated to be $\mathbf{1 2 8 . 6 \%}$ of the figures of the same site type in Sa.

4) Estimated to be $58.3 \%$ of the figures of the same site type in Kainuu.

5) For the estimation of diameter frequency distribution, the figures of SIRÉN (1955, pp. 99-102) have been used. 


\section{Data used in the socio-economic calculations}

The basis of estimation of the socio-economic prices of agricultural products was the price level in international trade. As a simple approximation the Finnish import or export prices in the period 1959-63 were used. These prices were compared with the prices applied by GULBRANDSEN (1969, p. 257) and the average producer prices in Denmark, and with the arithmetic averages of the EFTA and EEC-countries in 1961/62 (FAO, Prices ... 1963). In our calculations the first mentioned prices were modified by an increase of 25 per cent, assumed in the case of general restoration of the free trade (Gulbrandsen, p. 47). Milk prices were in our calculations modified also by pricing the average liquid milk proportion in line with the actual producer prices. Thus international prices were not applied to this part of milk production.

For the estimation of average producer prices of milk the average processing costs of dairies from the year 1961 were used. These data are given in the statistics of Cooperative Dairies (Osuusmeijerien Liiketilasto). This gives the costs, apart from those of collected milk and depreciation of the capital, separately for dairies selling butter, cheese or liquid milk.

\begin{tabular}{|c|c|c|c|c|c|c|}
\hline & $\begin{array}{c}\text { Import } \\
\text { or } \\
\text { export } \\
\text { price } \\
1959-63\end{array}$ & $\begin{array}{c}\text { Gul- } \\
\text { brandsen } \\
1961 / 62\end{array}$ & Denmark & $\begin{array}{c}\begin{array}{c}\text { EFTA } \\
\text { aver. }\end{array} \\
1961 / 62\end{array}$ & $\begin{array}{c}\text { EEC } \\
\text { aver. } \\
1961 / 62\end{array}$ & $\begin{array}{c}\text { Prices } \\
\text { applied } \\
\text { here }\end{array}$ \\
\hline 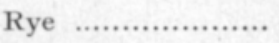 & $-: 20.5$ & . & . & . & . & $-: 25.6$ \\
\hline Whcat ................ & $-: 25.2$ & $-: 18.7$ & $-: 23.9$ & $-: 32.9$ & $-: 30.4$ & $-: 31.5$ \\
\hline Sugar beets .......... & $-: 04.9$ & . & $-: 04$ & $-: 04.9$ & $-: 04.6$ & $-: 06.1$ \\
\hline Potatoes ............... & . & $-: 09.3$ & . & . & . & . \\
\hline Butter ................. & $2: 60.5$ & $2: 65$ & . & . & . & $3: 26$ \\
\hline Edam-cheese .......... & $1: 54.6$ & $1: 53$ & . & . & . & $1: 93$ \\
\hline $\begin{array}{l}\text { Liquid milk .......... } \\
\text { Milk, producer }\end{array}$ & . & $-: 24.3$ & . & . & . & . \\
\hline price .................... & . & . & $-: 17.8$ & $-: 26.2$ & $-: 24.5$ & $-: 21$ \\
\hline 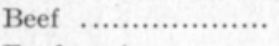 & $\left.2: 73^{1}\right)$ & $2: 24$ & $2: 28$ & $3: 25$ & 3:56 & $2: 85$ \\
\hline Feed grain ........... & . & $-: 18$ & . & . & . & $-: 22.5$ \\
\hline Oil cakes ................. & . & $-: 26.7$ & . & . & - & $-: 33.4$ \\
\hline
\end{tabular}

To complete the transport cost data the statistics of the Cooperative Dairies (Suomen Osuusmeijerien Liiketilasto) have been used. The depreciation has been estimated at 3 per cent of real estate and at 5 per cent of movables, assuming that these costs in the said groups are in the same proportion to the gross value of production. Thus tha costs, without those for transport, were 5.7, 8.8, 8.0 per cent of the gross value in the respective groups, or 7.55 per cent on averages for all dairies. As the use of milk per $\mathrm{kg}$ butter has in cooperative dairies been $19.4 \mathrm{~kg}$, and per $\mathrm{kg}$ cheese respectively $7.5 \mathrm{~kg}$, the costs per $\mathrm{kg}$ milk have been 1.86 and 3.26 p respectively, or when increased by transport costs, 3.36 and 4.76 p. Computed from the hypothetical free trade butter price (3.26), and noting the value of returned skim milk $(0.04$ per $\mathrm{kg}$ ), the net farm price of factory milk would be $17.4 \mathrm{p}$ in the case of butter production. In cheese production, the respective milk price would be $20.9 \mathrm{p}$ per $\mathrm{kg}$.

If the figures of the year 1961 on the distribution of milk for different uses (Pellervon Kalenteri) are applied, the average socioeconomic producer price of milk, and the contribution of milk transport and processing to the NNP can be computed as follows (average of the whole country):

1) Only the years 1959 and 1963. 


$\begin{array}{rrcccc} & \% & \begin{array}{c}\text { Producer } \\ \text { price }\end{array} & \begin{array}{c}\text { Contribution } \\ \text { processing }\end{array} & \begin{array}{c}\text { to NNP of } \\ \text { transport }\end{array} & \text { Total } \\ \text { Liquid milk consumed ..... } & 38.5 & -: 31.3 & -: 04.1 & -: 01 & -: 25.5 \\ \text { Factory milk, butter ....... } & 54.3 & -: 17.44 & -: 02.1 & -: 01 & -: 19.6 \\ \text { cheese ........ } & 7.2 & -: 20.9 & -: 03.9 & -: 01 & -: 24.9 \\ \text { Average .................. } & - & -: 23.0 & -: 03.0 & -: 01 & -: 19.6\end{array}$

The actual farm prices, as presented in this Appendix, p. 373, varied in our study areas. As the differences were due to subsidies, we do not take these differences into account so that the same price is used for all study areas.

There are no further complications in the estimation of socioeconomic prices, though some question marks might be applied to some single product prices. Compared with milk prices other prices play a rather small role in this study. - The prices of fertilizers and lime were subsidized; in 1961 the Government paid 14.01 mill. mk to reduce the sum paid by farmers to 93.87 mill. mk. The socio-economic prices of fertilizers can thus be obtained multiplying by 1.149. For the duties on corn, bran and oil cakes $(-: 08,-: 05$ and $-: 03$ per $\mathrm{kg}), 4.8 \mathrm{mill}$. $\mathrm{mk}$, were collected i.e. 0.25 per cent of the gross return of agriculture.

To estimate the respective socio-economic advantages, the contribution to the net national product (NNP) of the activities in the processing industries and transport had to be estimated. The national averages of Industrial Statistics (Teollisuustilasto 1961) and Railway Statistics (Rautatietilasto 1961) were used for this purpose. A detailed study by LindFors (1964) is very helpful when estimating the costs of lumber transport.

In the Industrial Statistics the value added approximately represents the Gross Natinal Product (GNP), while the NNP is obtained by a deduction of the yearly depreciation value. In the statistics the values of fixed capital, separately for real estate and movables, are presented for certain factory groups, and for this study a 3 per cent depreciation is used for real estate and 5 per cent for movables ${ }^{1}$ ). For further calculations, the overall total NNP is divided by the volume of raw material used (or in the case of slaughter houses, by the volume of product, i.e. the total weight of carcasses produced).

The contribution of transport to the NNP plays a not insignificant role in the agricultural calculations, and a rather important role in the calculations relating to forestry. The Railway Statistics includes the freights paid for some agricultural products and requisites in 1961. Truck transports have to some extent superseded railway conveyance, and in the absence of statistics only rough estimates are possible. Assuming that the railway transport volumes for the year 1955 reflect approximately the total transport volume in 1961, and using the 1961 tariffs, the figures presented beneath are obtained for other products. These again are estimated on the basis of statistics of Cooperative Dairies, which generally pay for the milk transports.

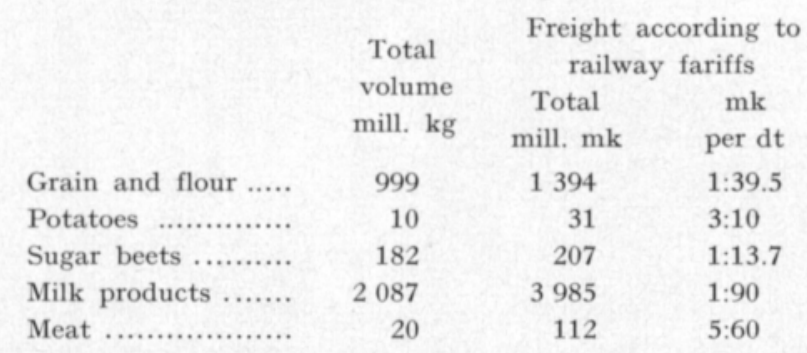

The contributions to the NNP of transports were estimated using the percentage ratios 84 and 48 , respectively for railway and truck transports. The former is based on the cost structure according to the Railway Statistics, the latter has been applied in the calculations of national income by the Central Office of Statistics.

1) In some cases when information is imperfect, the depreciation in a subgroup is estimated assuming the same percentage depreciation of gross revenue as in a larger group. 
Although we cannot feel entirely confident regarding the accuracy of these estimations, we may use the following approximations per unit, to indicate the contribution to the $\mathrm{NNP}, \mathrm{p} / \mathrm{kg}$.

$\begin{array}{lccr} & \text { Transport } & \text { Processing } & \text { Total } \\ \text { Grain } \ldots \ldots \ldots \ldots \ldots \ldots . & 1.17 & 6.71 & 7.88 \\ \text { Potatoes } \ldots \ldots \ldots \ldots \ldots . & 3.10 & - & 3.10 \\ \text { Sugar beets } \ldots \ldots \ldots \ldots & 1.14 & 5.35 & 6.49 \\ \text { Milk } \ldots \ldots \ldots \ldots \ldots \ldots \ldots & 0.93 & 3.00 & 3.93 \\ \text { Meat } \ldots \ldots \ldots \ldots \ldots \ldots \ldots & 5.60 & 29.60 & 35.20\end{array}$

These figures are not differentiated according to regions, as the volumes transported are very difficult to determine since industrial statistics give only domestic averages. As the importance of transport is more obvious in the regional estimations on forestry, an attempt is made to figure out the average distance the lumber has to be conveyed to the processing plants, as well as the most probable distances the processed products have to travel, separately for each of our study areas. In most cases there are alternative transport possibilities, e.g. truck, railway or floating; in some cases, the most probable way of transport is so clear that alternatives seem to be superfluous.

The assumed ways of transport and estimated distances (weighed by the productive forest acreage of subareas) are by the main study areas as follows:

\begin{tabular}{|c|c|c|c|c|c|}
\hline \multirow[t]{2}{*}{$\begin{array}{l}\text { Study } \\
\text { area }\end{array}$} & \multirow[t]{2}{*}{ Way of transport } & \multicolumn{4}{|c|}{$\begin{array}{l}\text { Aver. distances of } \\
\text { saw timber }\end{array}$} \\
\hline & & truck & train & truck & train \\
\hline SF & truck, floating $\ldots . \ldots \ldots \ldots \ldots \ldots . . . . . .$. & 62 & - & 62 & - \\
\hline W & truck, or train $\ldots \ldots \ldots \ldots \ldots \ldots \ldots$ & 87 & - & 87 & - \\
\hline MF & truck, train ....................... & 37 & 31 & 50 & 48 \\
\hline \multicolumn{6}{|l|}{ NE } \\
\hline Ssm & truck, train, floating ............ & 20 & 118 & 20 & 118 \\
\hline Ku & 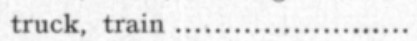 & 120 & - & 92 & 182 \\
\hline Sa & 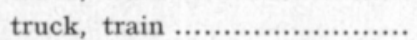 & 66 & - & 20 & 262 \\
\hline
\end{tabular}

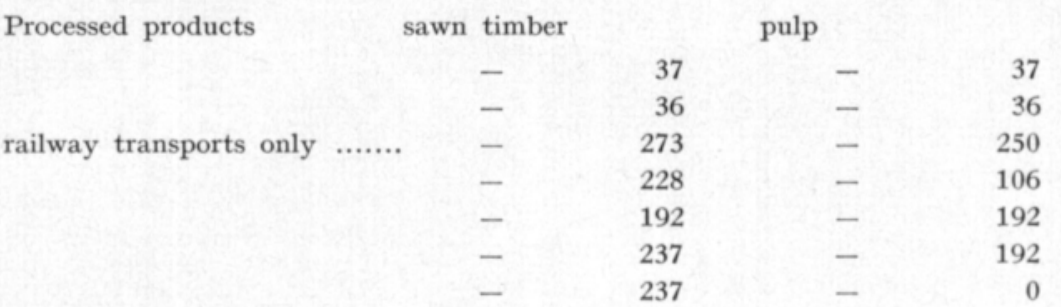

The costs of transport are estimated on the basis of the given distances and the data on the expenses per volume unit and road kilometre. The last mentioned data on unprocessed wood were found in an article by LINDFORs, in which the overall average costs in the year 1961 are stated separately for different kinds of lumber, and for tractor, truck, railway and floating transport separately. The costs of transport of sawn timber and pulp were, however, obtained from Railway Statistics. As the costs of truck transport are greatly affected by the distance, and some data are available on the differences, these costs were modified in the final computations by using graphical interpolation. The average costs used as the basis are the following: 
Average transport costs mk per cu. m. or per to $/ \mathrm{km}$

\begin{tabular}{|c|c|c|c|c|c|c|}
\hline & Tractor & Truck & Railway & Floating & $\begin{array}{l}\text { Truck } \\
50 \mathrm{~km}\end{array}$ & $\begin{array}{l}\text { Truck } \\
20 \mathrm{~km}\end{array}$ \\
\hline Saw logs ....................... & $0: 358$ & $0: 119$ & 0:036 & 0:019 & $0: 0105$ & 0:0195 \\
\hline Piled pulp wood ............. & $0: 271$ & 0:091 & $0: 026$ & $0: 018$ & $0: 0084$ & $0: 014$ \\
\hline Fuel wood .................... & $0: 288$ & $0: 129$ & $0: 018$ & $0: 038$ & . & . \\
\hline \multicolumn{7}{|l|}{ Sawn timber } \\
\hline heavy ...................... & . & . & $0: 0465$ & . & . & . \\
\hline battens, boards .......... & . & . & $0: 046$ & . & . & . \\
\hline Pulp .............................. & . & . & $0: 047$ & . & . & . \\
\hline
\end{tabular}

It was not possible fo estimate the extent of floating transports for this study. Consequently, these are not taken into account, which means that the computed costs may have been to some extent overestimated. Floating may have some relevance especially in the MF and Ssm study areas.

The contribution of transport to the NNP was estimated using the ratios already referred to (p. 11).

When estimating the contribution of industrial processing, the figures based on Industrial Statistics were used. (For the detailed figures, see Finnish Study Group, 1969, Appendix I.) It was assumed that the contribution of the paper industry can be added to that of the pulp industry in the same proportion as the pulp used as raw material is in relation to the total pulp production. As the paper factories use 46.7 per cent of the pulp produced, and the contribution is 9:91 per ton pulp, whereas $3.8 \mathrm{cu}$. m. (s) is needed per ton pulp, the average contribution of the paper industry is 1:22 per cu. m. (s) total use of pulp wood.

The figures presented here were applied in the computations of the NNP which is based on the primary production on the land of the study areas.

\section{NOTES AND ABREVIATIONS}

AA Asutustoiminnan Aikakauskirja. Journal of Colonization.

AAF Acta Agralia Fennica.

AFF Acta Forestalia Fennica.

FF Folia Forestalia. Institutum Forestale Fenniae, Helsinki.

MA Maataloustieteellinen Aikakauskirja. Journal of the Scientific Agricultural Society of Finland.

MAL Metsätaloudellinen Aikakauslehti.

MT Metsätilasto. Forest Statistics.

MTJ Metsätutkimuslaitoksen julkaisuja. Communicationes Instituti Forestalis Fenniae. Helsinki.

STV Suomen tilastollinen vuosikirja. Statistical Year Book of Finland.

Suo Suoviljelysyhdistyksen aikakauslehti. Journal of Peat Culture Society of Finland. SVT Suomen virallinen tilasto. Official statistics of Finland.

TSK Tilastoa Suomen Karjantarkkailuyhdistysten toiminnasta. Statistics of the activity of milk recording societies in Finland.

TSMT (P. I.) Tutkimuksia Suomen maatalouden kannattavuudesta. Investigations on the profitability of agriculture in Finland. Maatalouden taloudellisen tutkimuslaitoksen julkaisuja. Helsinki.

dt $\quad=$ deciton $(100 \mathrm{~kg})$.

fu. $\quad=$ Scandinavian fodder unit - rehuyksikkō.

cu. $\mathrm{m} .(\mathrm{p})=$ piled cu. $\mathrm{m}$. - pinokuutiometri

cu. $\mathrm{m} .(\mathrm{s})=$ cubic meter. Solid measure (with bark) - kiintokuutiometri (kuorellinen)

cu. ft. = cubic feet (techn. measure) - teknillinen kuutiojalka. 